\title{
Review: the energetic value of zooplankton and nekton species of the Southern Ocean
}

\author{
Fokje L. Schaafsma ${ }^{1} \cdot$ Yves Cherel $^{2} \cdot$ Hauke Flores $^{3} \cdot$ Jan Andries van Franeker ${ }^{1} \cdot$ Mary-Anne Lea $^{4} \cdot$ Ben Raymond $^{5,4,6}$. \\ Anton P. van de Putte ${ }^{7}$
}

Received: 8 March 2018 / Accepted: 5 July 2018 / Published online: 18 July 2018

(c) The Author(s) 2018

\begin{abstract}
Understanding the energy flux through food webs is important for estimating the capacity of marine ecosystems to support stocks of living resources. The energy density of species involved in trophic energy transfer has been measured in a large number of small studies, scattered over a 40-year publication record. Here, we reviewed energy density records of Southern Ocean zooplankton, nekton and several benthic taxa, including previously unpublished data. Comparing measured taxa, energy densities were highest in myctophid fishes (ranging from 17.1 to $39.3 \mathrm{~kJ} \mathrm{~g}^{-1} \mathrm{DW}$ ), intermediate in crustaceans (7.1 to $25.3 \mathrm{~kJ} \mathrm{~g}^{-1} \mathrm{DW}$ ), squid (16.2 to $24.0 \mathrm{~kJ} \mathrm{~g}^{-1} \mathrm{DW}$ ) and other fish families (14.8 to $29.9 \mathrm{~kJ} \mathrm{~g}^{-1} \mathrm{DW}$ ), and lowest in jelly fish (10.8 to $\left.18.0 \mathrm{~kJ} \mathrm{~g}^{-1} \mathrm{DW}\right)$, polychaetes $\left(9.2\right.$ to $\left.14.2 \mathrm{~kJ} \mathrm{~g}^{-1} \mathrm{DW}\right)$ and chaetognaths $\left(5.0-11.7 \mathrm{~kJ} \mathrm{~g}^{-1} \mathrm{DW}\right)$. Data reveals differences in energy density within and between species related to size, age and other life cycle parameters. Important taxa in Antarctic food webs, such as copepods, squid and small euphausiids, remain under-sampled. The variability in energy density of Electrona antarctica was likely regional rather than seasonal, although for many species with limited data it remains difficult to disentangle regional and seasonal variability. Models are provided to estimate energy density more quickly using a species' physical parameters. It will become increasingly important to close knowledge gaps to improve the ability of bioenergetic and food web models to predict changes in the capacity of Antarctic ecosystems to support marine life.
\end{abstract}

Responsible Editor: A. Atkinson.

Reviewed by J. Farber-Lorda, D. G. Ainley, B. Hunt.

Electronic supplementary material The online version of this article (https://doi.org/10.1007/s00227-018-3386-z) contains supplementary material, which is available to authorized users.

Fokje L. Schaafsma

fokje.schaafsma@wur.nl

1 Wageningen Marine Research, Ankerpark 27, 1781 AG Den Helder, The Netherlands

2 Centre d'Etudes Biologiques de Chizé, UMR 7372 du CNRS et de l'Université de La Rochelle, 79360 Villiers-en-Bois, France

3 Alfred-Wegener-Institut Helmholtz-Zentrum für Polar-und Meeresforschung, Am Handeshafen 12, 27570 Bremerhaven, Germany

4 Institute for Marine and Antarctic Studies, University of Tasmania, 20 Castray Esplanade, Battery Point, Hobart, TAS 7004, Australia

\section{Introduction}

The Southern Ocean is home to some of the largest populations of top predator species worldwide such as penguins, flying birds, seals and whales. It comprises the sub-Antarctic and Antarctic regions and is here defined as the water masses south of the Subtropical Front (STF), which separates the surface waters of the Southern Ocean from the warmer and

5 Australian Antarctic Division, Department of the Environment and Energy, 203 Channel Highway, Kingston, TAS 7050, Australia

6 Antarctic and Climate Ecosystems Cooperative Research Centre, University of Tasmania, Private Bag 80, Hobart, TAS 7001, Australia

7 Royal Belgian Institute of Natural Sciences, Vautierstraat 29, 1000 Brussels, Belgium 
more saline surface waters of subtropical circulations (Orsi et al. 1995; Belkin and Gordon 1996). To predict consequences of challenges to top predators, such as from climate change and increased fisheries, and to develop adequate conservation measures, a quantitative understanding of the energy flux in the ecosystem is important. The energy content of species is a key factor in models of energy flux in food webs and in the studies of trophic relationships between species (Van de Putte et al. 2006).

The life cycle and physiology of a species can strongly influence its energetic value. Organisms often have seasonal cycles in lipid content and consequently energy density (Hislop et al. 1991; Tierney et al. 2002). This is generally associated with the annual reproductive and feeding cycles (Hislop et al. 1991). Many species, for instance, acquire energy for reproduction, and therefore, have a high energy value just before spawning, and a lower one afterwards (Norrbin and Båmstedt 1984; Van de Putte et al. 2006; Fenaughty et al. 2008). Particularly in crustaceans, energy densities can vary between sexes (Färber-Lorda et al. 2009a). Lipid storage is used as buoyancy control in many marine animals, causing differences in energy content between animals with a different vertical distribution (Lawrence 1976). Furthermore, lipid content changes with size and age, greatly influencing energy content (Tierney et al. 2002; Färber-Lorda et al. 2009a; Färber-Lorda and Mayzaud 2010). Energy allocation for different purposes, such as growth or reproduction, most likely occurs simultaneously, but one purpose may dominate over others depending on locality and season (Båmstedt 1986).

Within a single species, the energetic value can vary between regions or seasons, due to differences in the type or amount of food (Williams and Robins 1979; Tierney et al. 2002; Van de Putte et al. 2006). Temperature and changes in food can, furthermore, influence the energy storage function of prey species (Ruck et al. 2014). Specifically at higher latitudes, the Southern Ocean experiences strong seasonality, with drastic changes in light availability between seasons and massive changes in sea-ice cover in many parts. In winter, the phytoplankton growth in the water column of both ice-covered and open water is greatly reduced (Arrigo et al. 1998, 2008). In ice-covered waters, algae and other fauna within and at the underside of the sea ice may provide the only source of primary production (Eicken 1992; Quetin and Ross 2003; Arrigo et al. 2008; Flores et al. 2011, 2012; Meiners et al. 2012; Schaafsma et al. 2017). A patchy and seasonally changing food distribution can cause frequent periods of starvation. Therefore, organisms living in harsher environment tend to have higher energy content, as they have adapted to the lower degree of predictability of food availability, and energy content and lipid stores of organisms tend to increase towards higher latitudes (Norrbin and Båmstedt 1984; Falk-Petersen et al. 2000).
The winter food scarcity has resulted in different overwintering strategies used by zooplankton and nekton living in the Southern Ocean such as relying on lipids reserves, reducing metabolic activity, dormancy, feeding on sea-ice resources, opportunistic feeding, combustion of tissue, or a combination of these (Torres et al. 1994; SchnackSchiel et al. 1998; Meyer et al. 2009; Kohlbach et al. 2017; Schaafsma et al. 2017). Species need to make optimal use of periods of high production, for instance to "fatten up" for winter and/or to gain enough energy for reproduction. Timing of reproduction can be important to ensure winter survival of young stages. Many species, therefore, have a specific strategy to make optimal use of spring phytoplankton blooms, which in ice-covered waters is initiated by sea-ice melt, or the peak summer phytoplankton production during their life cycle (Quetin and Ross 1991; Lizotte 2001).

The overwintering strategy utilized by zooplankton and nekton influences its seasonal physiology and consequently, energetic density. Species relying on reserves in winter often have a low energetic value by the end of this season (Torres et al. 1994). Organisms that have accumulated lipids for a time of low phytoplankton availability have relatively high lipid content and high energetic values. Therefore, higher energetic values are often found in herbivores in certain seasons (Donnelly et al. 1994). Species can also have a 'business as usual' overwintering strategy, encompassing opportunistic feeding combined with some combustion of tissue (Torres et al. 1994). This strategy is, for instance, adopted by deeper living zooplanktivorous species which do not necessarily experience a food decline during the winter months, as they have access to, e.g. calanoid copepods that sink out of the euphotic zone to overwinter in diapause (Bathmann et al. 1993; Torres et al. 1994; Kruse et al. 2010). Many larger crustaceans adopt a mixed strategy comprising a combination of opportunistic feeding, combustion of body mass, a lowered metabolic rate, and occasionally, negative growth (Ikeda and Dixon 1982; Quetin and Ross 1991; Torres et al. 1994). In general, the food supply is more variable for pelagic species as opposed to benthic species, as seasonal changes are less pronounced in deeper waters. Pelagic species often have a higher and more variable energy density compared to benthic species. This is attributed to the generally more variable food supply for pelagic species as opposed to benthic species, as seasonal changes are less pronounced in deeper waters (Norrbin and Båmstedt 1984).

Predation, seasonality, and subsequent life cycle strategy has influenced the behaviour and distribution of zooplankton and nekton species. This has consequences for the availability of zooplankton and nekton as a food source for predators, for example, prey species have different depth distribution between seasons (Ainley et al. 1991, 2006; Greely et al. 1999; Flores et al. 2014), prey species shift their horizontal distribution depending on growth and retreat of sea ice 
(Van Franeker 1992; Van Franeker et al. 1997; Flores et al. 2011) or schooling behaviour of prey species changes with food availability, seasons and/or regions which can change the catchability of this prey species for predators (Hamner et al. 1989; Kawaguchi et al. 2010). Therefore, the quality (in terms of energetic value) of available prey may change between seasons, possibly influencing the physiology, distribution and behaviour of predators (Ainley et al. 2015).

Information on the energetic value of prey can be used to predict the behaviour and population dynamics of predators, and to gain insight into key trophic interactions between species (Trathan et al. 2007). It is furthermore important for the calculation of the energy flux through trophic levels of marine ecosystems (Goldsworthy et al. 2001; Lea et al. 2002), the investigation of the importance of a particular prey species in the diet of a predator (Cherel and Ridoux 1992; Lea et al. 2002) and for the use in bioenergetics models (e.g. Hartman and Brandt 1995). The aim of this review is to summarize the knowledge on the energy density of zooplankton and nekton species of the Southern Ocean, for the potential utilization in trophodynamic studies and bioenergetic models. Although the focus is on zooplankton and nekton, benthic species are included. Previously unpublished data are also included in this study.

\section{Methods}

\section{Southern Ocean environmental framework}

South of the STF, the Southern Ocean comprises different water masses and zones with distinct characteristics, separated from each other by several fronts and currents, and is thus not ecologically uniform (Pakhomov and McQuaid 1996; Belkin 2007). Large regions such as the continental shelf and slopes, sub-Antarctic and Antarctic Island groups, features of different fronts, the deep ocean, banks and basins and large gyre systems can be separated having distinct environmental features (Grant et al. 2006). The dominating current of the Southern Ocean is the Antarctic Circumpolar Current (ACC), driven by westerly winds (Orsi et al. 1995; Belkin 2007). The surface water of the ACC has a northern boundary at the Sub-Antarctic Front (SAF). Within the ACC, the Antarctic Polar Front (APF) marks the boundary between warmer sub-Antarctic water and cold Antarctic surface water. The surface waters of the ACC do not show a clear boundary to the south, its properties being rather uniform from the APF to the continental margins. However, in the underlying circumpolar deep water a Southern Boundary (SB) of the ACC occurs (Orsi et al. 1995), which has been found to also influence the physical features of the overlying water (Nicol et al. 2000; Dinniman et al. 2011). The Weddell and Scotia Seas also have different characteristics and they are separated by the Weddell-Scotia confluence separating the ACC from the Weddell Gyre (Orsi et al. 1995; Belkin 2007). Although, the ACC consisting of aforementioned fronts is the classical view based on studies mainly conducted in the Drake Passage, the frontal structure can be more complex in different areas. More details on this can be found in Solokov and Rintoul (2009). Along the margins of the continent there is a westward current, the Antarctic Slope Current. The waters of the continental shelf and the oceanic waters are separated by the Antarctic Slope Front (Jacobs 1991), which in areas where the continental shelf is narrow coincides with the slope current (Heywood et al. 1998). In between the major currents there are various eddies, the largest being the Weddell Gyre and the Ross Gyre (Riffenburgh 2007). Temperature and salinity gradients often coincide with the shelf breaks leading to a separation between coastal and oceanic areas (Ainley and Jacobs 1981; Van de Putte 2008). Broadly, the oceanic area south of the APF can be separated in (from north to south) a permanent open ocean zone, a seasonal ice zone (SIZ) and a coastal and continental shelf zone, which are regarded as different sub-systems with specific mechanisms controlling nutrient and phytoplankton dynamics (Tréguer and Jacques 1992). More information in biogeographic regions can be found in De Broyer and Koubbi (2014).

\section{Measuring energy density}

\section{Bomb calorimetry}

Bomb calorimetry is the most direct method to analyse the energy content of a species. A bomb calorimeter establishes the energy density (the amount of energy per unit mass) of a plant or animal tissue sample by measuring the heat released when that sample is completely oxidized. The sample is placed in a combustion chamber filled with oxygen, which is surrounded by water. After ignition, the temperature rise in the surrounding water is measured and converted to calorific density. If a sample causes $1000 \mathrm{~g}$ of water to rise with $1{ }^{\circ} \mathrm{C}$, the calorific content of the sample is 1 kilocalorie (kcal; Shul'man 1974; Robbins 1983). The calorific density (cal $\mathrm{g}^{-1}$ weight) will then depend on the weight of the sample. To determine the whole-body energy density of an animal using bomb calorimetry, the animal is dried and homogenized. After ignition in the bomb calorimeter, the calorific density of the tissue per gram dry weight (DW) is obtained, DW representing the weight of the organic and inorganic contents of the body without any water. Following the Système international d'unités (SI), energetic densities are expressed in joule $(\mathrm{J})$ or kilojoules $(\mathrm{kJ})$. One kilocalorie equals $4.184 \mathrm{~kJ}$.

Depending on the intended use of the data, the energy density can be expressed in several ways. Expression 
in $\mathrm{kJ} \mathrm{g}^{-1}$ wet weight (WW) can be useful in studies of trophic relationships and predator distribution/abundance, for instance to translate energetic requirements into food requirements (in number of individuals or $\mathrm{kg}$ ) and is thus relevant for ecological considerations (Båmstedt 1986; Van Franeker 1992; Flores et al. 2008). However, the wet weight energy content of an individual is strongly related to its water content, the determination of which is a potential source of error. Samples are often weighed after being stored frozen and freezing samples causes dehydration. Calculating the 'wet' energetic value can, therefore, be skewed, as a lower water content will result in a higher wet weight energetic value (Hislop et al. 1991). Using fixation solutions also often results in loss of water or lipids and can, therefore, bias the relationship between WW, DW, chemical composition and energy content (Lamprecht 1999). Therefore, expression of energy density in $\mathrm{kJ} \mathrm{g}^{-1} \mathrm{DW}$ can be a better tool for comparison of the energy density within and between species.

As DW includes inorganic material, expression of the energetic density in $\mathrm{kJ} \mathrm{g}^{-1}$ ash-free dry weight (AFDW), representing the mass of only the organic part of the body or tissue, can in some cases be a more suited unit of measurement, for instance for growth and translocation studies (Lamprecht 1999). For energy comparison between tissues it is also more useful to use AFDW, because different tissues often have different ash contents (Lamprecht 1999). Although the literature sources suggest that ash content can be determined using the residue in the calorimeter cup after combustion (Lamprecht 1999), the more accurate determination is to make an independent estimate of the ash content of an organism (Paine 1971; Craig et al. 1978; Cherel and Ridoux 1992).

Measurements of organisms with high ash content can yield unrealistic energetic values. Ash consisting of high proportions of $\mathrm{CaCO}_{3}$ or other decomposable salts can cause endothermic reactions when subjected to the high temperatures present in the bomb calorimeter, leading to a loss of heat within the calorimeter and consequently an underestimation of the energy density (Paine 1964, 1971). This error increases with increasing ash content (Paine 1971). Therefore, caution should be taken with ash contents higher than 25\% (Paine 1971). Determination of the proportion of ash can also lead to errors due to the decomposition of salts (Paine 1971).

Measurements of energetic values lower than $17 \mathrm{~kJ} \mathrm{~g}^{-1}$ AFDW (the energetic density of carbohydrates) should be considered with caution, as they may be due to a wrong determination of ash content or to contributions of inorganic reactions during burning (Lamprecht 1999). Even though substances with lower calorific values exist, such as pyruvic acid and glycine, etc., it is unlikely that these substances substantially lower the energetic values of an individual organism (Paine 1971).
A bomb calorimeter typically oxidizes nitrogen to a greater degree than most aquatic organisms (except microorganisms), giving a higher estimate of energy than is actually available to a consumer. To account for this extra energy, a nitrogen correction can be used (Kersting 1972; Salonen et al. 1976). However, for such a correction it is necessary to know the amount of nitrogen in the sample, and correction can possibly vary depending on the organism (Kersting 1972). The energy density values obtained by bomb calorimetry are usually not corrected for nitrogen and may thus be slightly overestimated.

Bomb calorimetry measures the energy content of an organism as a whole. Part of this energy can; however, not be used by the consumer because food is often not completely digested or metabolized. Incomplete catabolism of protein leaves compounds (ammonium, urea, uric acid and creatinine) that are lost in urine (Brody 1945; FAO 2003). The digestibility of chitin, the main component of the exoskeleton of crustacea, can differ between species (Danulat 1987; Jackson et al. 1992), and carbohydrates can have indigestible parts often referred to as dietary fibre (FAO 2003). The energy density determined using bomb calorimetry is thus the gross energy of an organism. This, in contrast to, e.g. metabolizable energy or digestible energy, represents the total amount of energy that is potentially available (Brody 1945; Brett and Groves 1979; FAO 2003). For detailed studies that require knowledge on digestible energy, correction factors and recommendations can be found in Brody (1945) and the FAO (2003). Although analysing fresh tissue is best when using bomb calorimetry, freezing is regarded as the most suitable preservation method for samples, as chemical preservation methods (e.g. ethanol or formaldehyde) significantly affect the results (Giguère et al. 1989; BeneditoCecilio and Morimoto 2002; Hondolero et al. 2012).

\section{Proximate composition}

Apart from ash and water fractions, organisms have an organic fraction that can be regarded as being composed of lipids, proteins and carbohydrates. By analysing the relative proportion of these components in the body of an organism, the energetic value can be reconstructed using energetic conversion factors (Paine 1971).

The energy content of the different fractions can show slight variations due to differences in molecular structure (Båmstedt 1986), but conversion factors commonly used are $23.64 \mathrm{~kJ} \mathrm{~g}^{-1}$ AFDW (5.65 $\mathrm{kcal} \mathrm{g}^{-1}$ ) for proteins and $16.97 \mathrm{~kJ} \mathrm{~g}^{-1}$ AFDW (4.1 kcal g${ }^{-1}$ ) for carbohydrates (Brett and Groves 1979). For lipids, an energy content of $39.54 \mathrm{~kJ} \mathrm{~g}^{-1}$ AFDW (9.45 kcal g${ }^{-1}$ ) has often been used (Paine 1971 and references therein; Brett and Groves 1979). These values represent gross energy content of the compounds (Brody 1945; Brett and Groves 1979), which, similar 
to bomb calorimetry, does not take into account potential differences in digestibility between animals and substrates, and lost protein compounds (Brody 1945; FAO 2003). A factor of $36.40 \mathrm{~kJ} \mathrm{~g}^{-1}$ AFDW ( $8.7 \mathrm{kcal} \mathrm{g}^{-1}$ ) is suggested to be more appropriate for lipids, because lipid content in the body may be overestimated due to impurities in the lipid extract (Craig 1977; Craig et al. 1978). This may, however, vary between methods used (FAO 2003). As the energy density of lipids is almost twice as high as that of protein, higher lipid contents often result in a higher energetic value (Anthony et al. 2000). Therefore, differences in the lipid content of organisms can often predict differences in energy density. There are exceptions to this rule, however, as the energy density can also change significantly due to changes in, e.g. water or protein content, particularly during growth (Shul'man 1974; Donnelly et al. 1994). In addition, changes in protein content cause greater changes in an organism's weight compared to lipids (Shul'man 1974).

As carbohydrates usually contribute very little to the total dry body composition, this constituent is sometimes not considered in proximate analysis (Craig et al. 1978). The protein content of a body is sometimes estimated by measuring the total nitrogen content of a sample and then multiplying this with a factor 6.25, which is known as the Kjeldahl method (Craig et al. 1978). The protein content estimated using this method is often referred to as crude protein. For the energetic contribution of chitin to the total energy density, the same conversion factor as for carbohydrate is usually used (Clarke 1980; Donnelly et al. 1994). Such factors cannot always accurately represent the potentially large variability of energy content of proximate compounds. Therefore, estimating the energetic content by means of proximate compositions is potentially subject to more error than bomb calorimetry (Henken et al. 1986; Kamler 1992; Hartman and Brandt 1995; Higgs et al. 1995).

Several studies found a good agreement between energy densities estimated using proximate composition and measured with bomb calorimetry (Paine 1971; Vollenweider et al. 2011). Other studies, however, found significant discrepancies between energy densities established using both proximate composition and bomb calorimetry (Craig et al. 1978; Henken et al. 1986; Kamler 1992). Energetic densities based on proximate composition were on average $4.4 \%$ higher than values obtained with bomb calorimetry in Craig et al. (1978), while they were on average 3-4\% lower in Henken et al. (1986). The conversion factors do not take into account potential differences in heat of combustion of protein, depending on their amino acid composition, or the contribution of dietary fibre to carbohydrates, which have a lower energetic density (FAO 2003). Furthermore, methods used for measuring the relative contribution of different proximate compounds, as well as calculation of the energetic value, often differ between studies (Henken et al. 1986).
Therefore, bomb calorimetry is considered the preferable method for energy density estimation (Henken et al. 1986; Kamler 1992; Hartman and Brandt 1995; Higgs et al. 1995). An advantage of proximate composition measurements is that changes in energy density can be related to changes in particular components that can give additional information on, e.g. ecological strategies, feeding activity, trophodynamics and reproductive status (Lawrence and Guille 1982; McClintock and Pearse 1987; Donnelly et al. 1994). A clear recommendation on the preservation of samples for proximate composition analysis was not found, but samples are usually processed directly or stored frozen.

\section{Water content, carbon content and energy density}

A relationship between energy density and water content is often found, showing an increase in water content with decreasing energy content (on a WW basis) and vice versa (Båmstedt 1981; Torres et al. 1994; Hartman and Brandt 1995). This can be attributed to water and lipids or protein replacing each other, depending on age, season and reproductive state (Torres et al. 1994; Hartman and Brandt, 1995; Lea et al. 2002; Tierney et al. 2002; Van de Putte et al. 2006). For example, the water content increases when lipids (or protein) are combusted (Torres et al. 1994). The relationship between water, lipid and protein content in fish changes with age because younger individuals would use the protein to build-up the body, but when growth ceases and protein metabolism stabilizes, the fish switch to the accumulation of fat (Shul'man 1974). Protein growth occurs in adult fishes in the form of gonad development (Shul'man 1974). Protein and lipid accumulation can, however, also depend on availability and composition of food. For example, in two species of anchovy with similar energy densities, one species had less available food, was larger at same age and contained more protein and less fat, while the other species had more food available, was fatter, but also smaller and contained less protein (Shul'man 1974). The water content/energy density (WW) relationship is also common in crustaceans (Torres et al. 1994). Exceptions are found, however, in for instance decapod, amphipod and krill species, where water and lipids do not replace each other, but increase or decrease simultaneously, or where changes in one of the fractions do not lead to changes in the other (Torres et al. 1994).

Relationships have also been found between total carbon content and energy density. Platt and Irwin (1973), Salonen et al. (1976), Finlay and Uhlig (1981), Gnaiger and Bitterlich (1984) and Normant et al. (2002) show regressions to calculate energy density. Different studies show relationships using different parameters and variable methods to establish both carbon content and energy density, making it hard to compare them. Measurements were done on phytoplankton (Platt and Irwin 1973), protozoa (Salonen et al. 1976; Finlay 
and Uhlig 1981) and crabs (Normant et al. 2002). Platt and Irwin (1973) make a regression calculating calories $\mathrm{mg}^{-1}$ DW using the total \% carbon, while Salonen et al. (1976) calculate $\mathrm{kJ} \mathrm{g}^{-1}$ AFDW using the total \% carbon, the former having a negative intercept, while the latter has a positive one. The relationship found by Normant et al. (2002), between $\mathrm{kJ} \mathrm{g}^{-1} \mathrm{DW}$ and \% carbon, also has a negative intercept, and a relatively low $R^{2}(0.61)$, suggesting that a relatively low proportion of the variability was explained by the regression. Finlay and Uhlig (1981) calculate energy density in terms of $\mathrm{kJ} \mathrm{g}^{-1}$ DW based on $\mathrm{mg} \mathrm{C} \mathrm{mg}^{-1}$ DW. FärberLorda et al. (2009a) shows a regression between carbon and energy in krill, with values based on $\mathrm{mg}_{\text {ind }}{ }^{-1}$ and $\mathrm{J}_{\text {ind }}{ }^{-1}$. In addition to regressions, factors to convert carbon to energy density were suggested. Salonen et al. (1976) suggested a conversion factor of $45.7 \mathrm{~kJ}$ (AFDW) $\mathrm{g}^{-1}$ organic carbon while Finlay and Uhlig (1981) suggested $46 \mathrm{~kJ} \mathrm{~g}^{-1}$ organic carbon. A conversion factor of $50.2 \mathrm{~kJ} \mathrm{~g}^{-1} \mathrm{C}$ was suggested based on measurements on the amphipod Themisto compressa, caught in the North Atlantic (Williams and Robins 1979). Due to differences in regression slopes and intercepts, measured species or species groups, and differences in units used, it remains unclear if the conversion factors and regressions can be used in a general context. It is also likely that season, region, organism, size and age will affect the carbon-energy density relationship, and these influences need to be assessed. Therefore, carbon content was not used in this review to estimate the energy density of species.

\section{Data and statistics}

In this review, we aimed to express all energy density values in $\mathrm{kJ} \mathrm{g}^{-1} \mathrm{DW}$ for species comparison and in $\mathrm{kJ} \mathrm{g}^{-1} \mathrm{WW}$ for use in ecological studies. When possible, the energy density values obtained from the literature were recalculated to $\mathrm{kJ} \mathrm{g}^{-1} \mathrm{DW}$ and/or $\mathrm{kJ} \mathrm{g}^{-1} \mathrm{WW}$ using given energy densities, species weights or water contents reported in the references concerned. Energy density values, determined by proximate composition, were calculated by the original authors using a factor of $36.40 \mathrm{~kJ} \mathrm{~g}^{-1}$ AFDW for the conversion of the lipid fraction, unless stated otherwise. Protein values represent actual measurements derived from true protein content analysis. When crude protein measurements were used in the original paper, this is specified. We also calculated energy densities from references reporting only proximate composition values (usually given in $\% \mathrm{WW}$ ) using the above mentioned conversion factors. When the carbohydrate fraction was not given in the source, we assumed it to be the remainder of $100 \%$ minus the other fractions (water content, lipids, carbohydrate, protein, ash, and where relevant, chitin). The lengths of fish reported in this review are given in standard length (SL), measured from the most forward part of the head to the end of the vertebrae. Some lengths are given in total length (TL), which is measured from the most forward part of the head to the end of the caudal fin.

Previously unpublished data obtained during two expeditions have been included in this review. Individual zooplankton and nekton species were collected on board the RV Polarstern in the Weddell Sea (PS81: August-October 2013) and in the Lazarev Sea (PS89: December/January 2014/2015), using Rectangular Midwater Trawls (RMT) and Surface and Under-Ice Trawls (SUIT). Details on sampling procedures, research area and environmental conditions for PS81 and PS89 can be found in Schaafsma et al. (2016) and Flores et al. (2015), respectively. After collection, zooplankton and nekton species were frozen at $-20^{\circ} \mathrm{C}$. Before the analysis of energetic value, samples were defrosted, blotted dry, and length and WW were measured. Then samples were freeze-dried until complete desiccation and re-weighted to determine DW and water content. After homogenization, a subsample of approximately $0.5 \mathrm{~g}$ was used for calorimetry. If necessary, individuals were pooled to obtain a sufficient amount of material to enable energy density measurements. The energy density (in $\mathrm{kJ} \mathrm{g}^{-1} \mathrm{DW}$ ) of samples was determined with an isoperibol bomb calorimeter (IKA C2000 basic), calibrated with benzoic acid. Benzoic acid $\left(29.62 \mathrm{~kJ} \mathrm{~g}^{-1} \mathrm{DW}\right.$ ) was added to samples that were too small to obtain a minimum sample weight of $0.5 \mathrm{~g}$. Some jelly fish body parts did not combust in the bomb calorimeter, most likely due to high ash contents ( $>75 \% \mathrm{DW})$. These tissues were then measured again using a sample consisting of half tissue, half benzoic acid. The AFDW of the jelly fish was obtained by drying a homogenized sample to constant mass at $60{ }^{\circ} \mathrm{C}$, followed by $6 \mathrm{~h}$ incineration at $500{ }^{\circ} \mathrm{C}$.

In datasets with a sufficient sample size, energy densities were compared using two-way ANOVA followed by a non-parametric Tukey's HSD post hoc test. Linear relationships between DW and energy content were established using ln-transformed data (Van de Putte et al. 2006). Linear relationships between water content and wet weight energy density were also investigated. Slopes and intercept of regression models were compared using ANCOVA (Hartman and Brandt 1995). All analyses were performed with $\mathrm{R}$ version 3.3.1 ( $\mathrm{R}$ Core Team 2015). Seasons listed within the tables are defined as stated by the authors, or as summer for December to February, autumn for March to May, winter for June to August and spring for September to November. It should be kept in mind that environmental conditions may vary within a month depending on region. All data used in this review, including the previously unpublished data, are available as part of the SCAR Southern Ocean Diet and Energetics Database, which is a compilation of diet and energetics data from Southern Ocean studies. More information on use and contributing can be found at https://www. scar.org/data-products/southern-ocean-diet-energetics/. 


\section{Energy density of zooplankton and nekton species}

\section{General overview}

Energetic densities of zooplankton and nekton species from sub-Antarctic and Antarctic waters collected and found in the literature included crustaceans such as copepods, euphausiids, amphipods, mysids and decapods, fish, squid, and gelatinous species. The numbers of records varied greatly between groups and species. Some species have been given more attention than others which is often related to their abundance, importance in the diet of top predators, commercial interest and catchability. Figure 1 shows an overview of all reported dry weight energy densities per species group and the locations at which recorded animals were sampled.

The majority of measurements of energy content in Antarctic crustaceans were conducted on euphausiids. The most comprehensive studies of energy density of crustaceans other than euphausiids were conducted by Donnelly et al. (1994) and Torres et al. (1994), using proximate composition. These studies provide, to our knowledge, almost the only records of energy densities of copepod, amphipod, decapod, mysid and ostracod species, which were caught in autumn and winter in the north-western Weddell Sea and the southern Scotia Sea. Donnelly et al. (1994) noted that their estimates of energy density are in general relatively low due to the incomplete recovery of organic material during analysis. Copepods showed a wide range of dry weight energy density values including very low values. Other low values were in general found for amphipods and ostracods. Amphipods have the highest skeletal ash, suggesting a more robust exoskeleton compared to copepods, euphausiids, decapods and mysids (Percy and Fife 1981; Torres et al. 1994). This can result in a lower dry-weight energy density because smaller proportion of the DW encompasses organic material. Amphipods furthermore have the highest chitin content (Donnelly et al. 1994; Torres et al. 1994). However, two measurements on amphipods using bomb calorimetry yielded an energy density similar to the other crustaceans. It is unclear if this was is an artefact of the different methods used, as all other energy densities were estimated using proximate composition, or due to a different life cycle and/or distribution of the species. Ostracods had a low lipid content and slightly higher ash content compared to other crustaceans except amphipods (Donnelly et al. 1994).


Fig. 1 a Overview of energy density records per species group. One point represents an average energetic value per species and per record. A distinction is made between measurements done using bomb calorimetry (BC) and proximate composition (PC). Note that one literature source can contain multiple energy density records, for instance of different species or developmental stages, and that, therefore, one point does not represent one literature source. b Overview map of energy density records, including several fronts. One point on the map represents one source. Therefore, a single point can include multiple measurements on a single species or measurements of multiple species from a single group. Approximate locations were derived from the source material. The map was made using Quantarctica from the Norwegian Polar Institute (Matsuoka et al. 2018). Mean front positions were taken from Solokov and Rintoul (2009). Previously unpublished data are included 
In terms of energetic measurements, fish are the most studied organisms in the Southern Ocean. The main focus lies on nototheniid, myctophid and bathylagid species. The lipid content of myctophids is in general high, while nototheniids are more variable in composition, which shows a difference between the two families that is possibly related to habitat use (Lenky et al. 2012). This is reflected in their dry-weight energy density, which was generally high for myctophids, while for nototheniids it ranged from values similar to crustaceans to values similar to myctophid fish. Dry-weight energetic densities of fish from other families, including Bathylagus antarcticus and Notolepis coatsi, were also comparable to those of crustaceans or the lower end of the range of nototheniids (Fig. 1). A similar range was found for squid.

Dry-weight energy densities of other groups showed relatively low values with the exception of a gastropod species, Clione limacina antarctica (Bryan et al. 1995). Measuring the energy content of gelatinous species is difficult due to their low proportion of organic material (high ash content), and high water content. A large part of the inorganic ash can be attributed to salt; a result from the large volume of sea water constituting the bulk of the organism's tissue (Percy and Fife 1981; Norrbin and Båmstedt 1984). In jellyfish it is thought that residual water remains, even after drying to constant mass. This residual water is estimated to be 11.7\% DW (Larson 1986; Doyle et al. 2007). For these reasons bomb calorific measurements and proximate composition estimates of gelatinous species should be considered with caution (Doyle et al. 2007). The high ash content can furthermore explain the low dry-weight energy density values of gelatinous species such as jelly fish, salps and siphonophores.

\section{Crustaceans}

\section{Copepods}

Copepods are the numerically dominant zooplankton group and often also dominate in biomass (Foxton 1956; SchnackSchiel et al. 2001; Atkinson et al. 2012; David et al. 2017). Therefore, they are an important part of the diet of many zooplanktons, fish and some top predator species (Laws 1977; Gon and Heemstra 1990; Hubold and Ekau 1990; Bocher et al. 2002; Van Franeker et al. 2002). Many species found in the Antarctic and sub-Antarctic regions have a wide distribution and are found north of the STF, sometimes even as far north as the Arctic Ocean (Kouwenberg et al. 2014). Of the total 388 species that have been reported to occur in the Southern Ocean, 53 are endemic south of the APF (Kouwenberg et al. 2014) and often rare. Many copepods can also be found residing within the sea ice (Schnack-Schiel et al. 2001; Arndt and Swadling 2006).
The energy densities of copepods estimated in Donnelly et al. (1994) ranged between 9.0 and $21.8 \mathrm{~kJ} \mathrm{~g}^{-1} \mathrm{DW}$. Highest energy densities were from Paraeuchaeta antarctica (21.8 $\left.\mathrm{kJ} \mathrm{g}^{-1} \mathrm{DW}\right)$, Calanus propinquus $\left(21.3 \mathrm{~kJ} \mathrm{~g}^{-1} \mathrm{DW}\right)$ and Calanoides acutus (17.6 $\left.\mathrm{kJ} \mathrm{g}^{-1} \mathrm{DW}\right)$ which were all caught in autumn. All three species have a wide distribution and occur from south of the STF to the Antarctic continent (Kouwenberg et al. 2014). The other species analysed in Donnelly et al. (1994) showed energy densities below $13.8 \mathrm{~kJ} \mathrm{~g}^{-1} \mathrm{DW}$. An overview of recorded copepod average energy density measurements including, where possible, values expressed in $\mathrm{kJ} \mathrm{g}^{-1} \mathrm{WW}$ can be found in Table $\mathrm{S} 1$ of the electronic supplement.

Some observations on energy content of copepods by Donnelly et al. (1994) can be explained by their life cycle, overwintering strategy and/or food. Species such as $C$. $a c u$ tus and C. propinquus are mainly herbivorous and have high lipid levels (Donnelly et al. 1994), resulting in a relatively high energy density. More omnivorous species, such as Euchirella rostromagna and Gaetanus tenuispinus, or carnivorous species, such as Heterorhabdus spp. have lower lipid levels (Donnelly et al. 1994). There are, however, exceptions to this pattern: the carnivorous Paraeuchaeta antarctica was found to have a high lipid content and the herbivorous Rhincalanus gigas has a relatively moderate lipid content, the latter attributed to their more flexible 2-year life cycle including a delayed reproduction (Donnelly et al. 1994). Heterorhabdus austrinus continues to feed during winter which is reflected in higher protein content and lower lipid content compared to its congener $H$. farrani, which does not feed during winter. Their estimated energy content was, however, similar $\left(12.1 \mathrm{~kJ} \mathrm{~g}^{-1} \mathrm{DW}\right.$; Donnelly et al. 1994).

All species that were analysed in two seasons showed a similar or lower energy density in winter compared to autumn, except for Rhincalanus gigas. Calanoides acutus overwinters at depth in diapause and did not show a difference in proximate composition between seasons which could be attributed to its reduced metabolic rates (Donnelly et al. 1994). This could also be the case for $R$. gigas, although this species has also been found to feed and reproduce during winter (Atkinson 1998). Calanus propinquus, overwintering using a combination of continuous feeding, reduction in body integrity and combustion of energy reserves, shows an increase in water level, and a decrease in chitin content and lipid levels from autumn to winter (Donnelly et al. 1994). As $C$. propinquus relies on energy reserves, their energy content can be expected to show large variations between seasons. Changes from autumn to winter were observed in the composition of Paraeuchaeta antarctica which was suggested to be a consequence of reproductive demand. Their energy content was, however, similar in both seasons (Donnelly et al. 1994). Studies on the lipids of copepods indicated 
that seasonal as well as regional variability of lipid content can be found within species, due to differences in food availability, type of food and overwintering strategy (Hagen et al. 1993; Donnelly et al. 1994).

\section{Euphausiids}

Euphausiids are a major component of Southern Ocean ecosystems. The three most studied species of Euphausiacea are Euphausia superba, Thysanoessa macrura and Euphausia crystallorophias. Euphausia superba has a circumpolar distribution, from south of the polar front to the continental shelf, with a majority of the total stock found in the regions of the Antarctic Peninsula and the Scotia Arc (Atkinson et al. 2008; Pakhomov et al. 2000; Flores et al. 2012). Thysanoessa macrura has a similar distribution but can also be found north of the SAF (Pakhomov et al. 2000; Atkinson et al. 2012; Flores et al. 2012; Cuzin-Roudy et al. 2014). The distribution and density of $E$. superba has been related to sea ice, although this association differs between seasons, while the smaller T. macrura can be found in ice-covered waters but is less ice-associated and often occupies a deeper stratum (Nordhausen 1994; Flores et al. 2012; Haraldsson and Siegel 2014). Euphausia crystallorophias is neritic and found close to the Antarctic continent (Nordhausen 1994; Pakhomov and Perissinotto 1996), where they reside in ice-covered waters year-round. For all krill species, larvae, juveniles and adult have different physiological, metabolic and functional adaptations and can, therefore, have different habitat requirements (Cuzin-Roudy et al. 2014). The largest species, E. superba, is the most heavily studied due to its high total biomass, its importance in the diet of many top predators and because it is a target species of a growing fishery (Atkinson et al. 2012).

The lowest average energetic density for E. superba was $15.2 \mathrm{~kJ} \mathrm{~g}^{-1} \mathrm{DW}$ for adults during autumn, estimated using proximate composition (Torres et al. 1994). The highest density found in the literature is $22.7 \mathrm{~kJ} \mathrm{~g}^{-1} \mathrm{DW}$ of gravid females at South Georgia during summer (Clarke 1980), although another source reports a somewhat lower energetic density for gravid females $\left(20.1 \mathrm{~kJ} \mathrm{~g}^{-1} \mathrm{DW}\right)$ found at Elephant Island (Ishii et al. 2007). Both aforementioned energy densities were estimated using proximate composition, but differences in methodological details used could have resulted in different values. Ishii et al. (2007), for instance, did not take the chitin fraction into account and details on the methods used for different components are undescribed. For the energy densities of T. macrura, E. crystallorophias and Euphausia frigida, estimates using bomb calorimetry, proximate composition and calculations using published equations (Färber-Lorda 1986; Torres et al. 1994; Ainley et al. 2003; Ruck et al. 2014) suggest that the energy density of these krill species is similar to that of E. superba. Bomb calorific measurements on adult and juvenile T. macrura from the southern Indian Ocean showed that individuals at one station $\left(6.1\right.$ and $5.4 \mathrm{~kJ} \mathrm{~g}^{-1}$ WW, respectively) had higher WW energy density values than individuals from another station $\left(5.5\right.$ and $4.8 \mathrm{~kJ} \mathrm{~g}^{-1}$ WW, respectively; Färber-Lorda 1986). A measurement of the mesopelagic, circumpolarly distributed Euphausia triacantha (Piatkowski 1985; Atkinson et al. 2012) showed that this species had a relative low energy density compared to the other euphausiid species from the same study (Torres et al. 1994). An overview of recorded euphausiid average energy density measurements including, where possible, values expressed in $\mathrm{kJ} \mathrm{g}^{-1} \mathrm{WW}$ can be found in Table 1.

The energy density of E. superba varies between regions, seasons, sexes and states of sexual maturity. Mature females have a high energy density and lose up to $55-58 \%$ of their lipids when spawning, resulting in a lower energetic value (Clarke 1980; Färber-Lorda et al. 2009b). Euphausia superba spawns from December to April with a peak in January (Ross and Quetin 1986; Pakhomov 1995; Spinidonov 1995). During summer, the energetic density of males is relatively low compared to juveniles and females (Clarke 1980; Färber-Lorda et al. 2009a). Studies suggest that this is due to differences in lipid accumulation, which was found to be low in males and at a maximum in maturing females, although a lot of variance was found (Pond et al. 1995; Mayzaud et al. 1998; Färber-Lorda et al. 2009a; Ruck et al. 2014). Lower lipid content in males is assumed to be a result of a higher investment of energy in growth to increase reproductive success (Ruck et al. 2014). Virtue et al. (1996) suggested that low accumulation of lipids in male krill is a result of a higher sexual activity. Multiple linear regressions between dry weight, carbon content, and lipid content versus energy content of E. superba, reported as values individual ${ }^{-1}$, can be found in Färber-Lorda et al. (2009a).

Similar differences in lipid content between males and females were found for T. macrura (Färber-Lorda and Mayzaud 2010). The lipid content of E. superba and T. macrura showed a high local variability in several studies (Pond et al. 1995; Hagen et al. 1996; Mayzaud et al. 1998; Färber-Lorda et al. 2009a; Färber-Lorda and Mayzaud 2010; Ruck et al. 2014; Kohlbach et al. 2017). In E. superba lipid, but also protein content, was found to be highly variable within a single population during several seasons, and the variety within a season can be greater than between seasons (Torres et al. 1994; Mayzaud et al. 1998; Ruck et al. 2014). This intra-seasonal variation can be attributed to a patchy and/or regionally variable distribution of available food (Mayzaud et al. 1998; Ruck et al. 2014; Virtue et al. 2016; Schaafsma et al. 2017).

As the spawning seasons of T. macrura and $E$ crystallorophias are somewhat earlier in the year compared to $E$. 
Table 1 Overview of the average energy density of several euphausiid species \pm , were available, the standard error (SE) or standard deviation (SD) as given in the original source

\begin{tabular}{|c|c|c|c|c|c|c|c|c|}
\hline \multirow[t]{2}{*}{ Season } & \multirow[t]{2}{*}{ Location } & \multirow[t]{2}{*}{$n$} & \multirow[t]{2}{*}{ Stage } & \multirow{2}{*}{$\begin{array}{l}\text { Water } \\
\text { Content (\%) }\end{array}$} & \multicolumn{2}{|c|}{ Mean energy density } & \multirow[t]{2}{*}{ Method } & \multirow[t]{2}{*}{ Source } \\
\hline & & & & & $\mathrm{kJ} \mathrm{g}^{-1} \mathrm{WW}$ & $\mathrm{kJ} \mathrm{g}^{-1} \mathrm{DW}$ & & \\
\hline \multicolumn{9}{|c|}{ Euphausia superba } \\
\hline \multirow[t]{18}{*}{ Summer } & South Georgia & $5-20$ & Female (gravid) & 76.0 & $5.45^{\mathrm{a}, \mathrm{b}}$ & 22.66 & $\mathrm{PC}$ & Clarke (1980) \\
\hline & Elephant Island & 4 & Female (gravid) & $75.9 \pm 0.4 \mathrm{SE}$ & $\begin{array}{l}4.80^{\mathrm{a}, \mathrm{c}} \pm 0.05 \\
\mathrm{SE}\end{array}$ & 20.08 & $\mathrm{PC}$ & Ishii et al. (2007) \\
\hline & $\begin{array}{l}\text { Southern Indian } \\
\text { Ocean }\end{array}$ & 7 & Female (spent) & & $4.88 \pm 0.78 \mathrm{SD}$ & & $\mathrm{MBC}$ & $\begin{array}{l}\text { Färber-Lorda } \\
\text { et al. (2009a) }\end{array}$ \\
\hline & Lazarev Sea & $3(\mathrm{p})$ & Female & $73.8 \pm 1.9 \mathrm{SD}$ & $5.54 \pm 0.73 \mathrm{SD}$ & $22.27 \pm 0.72 \mathrm{SD}$ & $\mathrm{BC}$ & This study (PS89) \\
\hline & $\begin{array}{l}\text { Southern Indian } \\
\text { Ocean }\end{array}$ & 15 & Female & & $6.31 \pm 0.88 \mathrm{SD}$ & & $\mathrm{MBC}$ & $\begin{array}{l}\text { Färber-Lorda } \\
\text { et al. (2009a) }\end{array}$ \\
\hline & WAP & (p) & Female & & & $22.0 \pm 0.3 \mathrm{SE}$ & $\mathrm{BC}$ & Ruck et al. (2014) \\
\hline & Elephant Island & 2 & Female & $77.7 \pm 1.3 \mathrm{SE}$ & $\begin{array}{l}4.16^{\mathrm{a}, \mathrm{c}} \pm 0.33 \\
\mathrm{SE}\end{array}$ & 17.41 & $\mathrm{PC}$ & Ishii et al. (2007) \\
\hline & South Georgia & $5-20$ & Male & 80.1 & $3.83^{\mathrm{a}, \mathrm{b}}$ & 19.22 & $\mathrm{PC}$ & Clarke (1980) \\
\hline & $\begin{array}{l}\text { Southern Indian } \\
\text { Ocean }\end{array}$ & 10 & Male & & $4.76 \pm 0.96 \mathrm{SD}$ & & MBC & $\begin{array}{l}\text { Färber-Lorda } \\
\text { et al. (2009a) }\end{array}$ \\
\hline & WAP & (p) & Male & & & $19.5 \pm 0.5 \mathrm{SE}$ & $\mathrm{BC}$ & Ruck et al. (2014) \\
\hline & Elephant Island & 4 & Male & $78.9 \pm 0.5 \mathrm{SE}$ & $\begin{array}{l}3.73^{\mathrm{a}, \mathrm{c}} \pm 0.12 \\
\mathrm{SE}\end{array}$ & 15.61 & $\mathrm{PC}$ & Ishii et al. (2007) \\
\hline & Elephant Island & 2 & $\begin{array}{l}\text { Male (sub- } \\
\text { adult) }\end{array}$ & $77.9 \pm 0.3 \mathrm{SE}$ & $\begin{array}{l}4.09^{\mathrm{a}, \mathrm{c}} \pm 0.03 \\
\mathrm{SE}\end{array}$ & 17.11 & $\mathrm{PC}$ & Ishii et al. (2007) \\
\hline & Lazarev Sea & $2(\mathrm{p})$ & Juvenile & $75.1 \pm 3.5 \mathrm{SD}$ & $5.63 \pm 1.19 \mathrm{SD}$ & $22.38 \pm 0.44 \mathrm{SD}$ & $\mathrm{BC}$ & This study (PS89) \\
\hline & $\begin{array}{l}\text { Southern Indian } \\
\text { Ocean }\end{array}$ & 10 & Juvenile & & $5.59 \pm 0.76 \mathrm{SD}$ & & $\mathrm{MBC}$ & $\begin{array}{l}\text { Färber-Lorda } \\
\text { et al. (2009a) }\end{array}$ \\
\hline & WAP & (p) & Juvenile & & & $20.8 \pm 1.7 \mathrm{SE}$ & Calc & Ruck et al. (2014) \\
\hline & Elephant Island & 1 & Juvenile & 78.3 & $4.0^{\mathrm{a}, \mathrm{c}}$ & 16.74 & $\mathrm{PC}$ & Ishii et al. (2007) \\
\hline & WAP & 9 & & $77.0 \pm 2.7 \mathrm{SD}$ & 5.01 & $21.8 \pm 0.7 \mathrm{SD}$ & $\mathrm{BC}$ & $\begin{array}{l}\text { Nagy and Obst } \\
\text { (1992) }\end{array}$ \\
\hline & & & & 75.7 & 4.86 & 20.0 & $\mathrm{PC}$ & $\begin{array}{l}\text { Yanagimoto et al. } \\
(1979)^{\mathrm{e}}\end{array}$ \\
\hline $\begin{array}{r}\text { Summer/ } \\
\text { autumn }\end{array}$ & East Antarctica & 1 & & & 4.47 & & $\mathrm{BC}$ & $\begin{array}{l}\text { Tamura and Koni- } \\
\text { shi (2009) }\end{array}$ \\
\hline \multirow[t]{3}{*}{ Autumn } & & & & 75 & 5.31 & 22.22 & $\mathrm{PC}$ & $\begin{array}{l}\text { Márquez et al. } \\
(1978)^{\mathrm{e}}\end{array}$ \\
\hline & Weddell Sea & 23 & Adult & $73.3 \pm 3.4 \mathrm{SD}$ & $4.07^{\mathrm{f}}$ & 15.24 & $\mathrm{PC}$ & $\begin{array}{l}\text { Torres et al. } \\
\text { (1994) }\end{array}$ \\
\hline & & & & 76.5 & 4.71 & 20.0 & $\mathrm{BC}$ & Jackson (1986) \\
\hline Winter & Scotia Sea & 32 & Adult & $77.3 \pm 3.4 \mathrm{SD}$ & $3.80^{\mathrm{f}}$ & 16.75 & $\mathrm{PC}$ & $\begin{array}{l}\text { Torres et al. } \\
\text { (1994) }\end{array}$ \\
\hline \multicolumn{9}{|c|}{ Thysanoessa macrura } \\
\hline \multirow[t]{6}{*}{ Summer } & WAP & (p) & & & & $28.5 \pm 2.8 \mathrm{SE}$ & Calc & Ruck et al. (2014) \\
\hline & $\begin{array}{l}\text { Southern Indian } \\
\text { Ocean }\end{array}$ & $1(\mathrm{p})$ & Adult & & 5.52 & & $\mathrm{MBC}$ & $\begin{array}{l}\text { Färber-Lorda } \\
\text { (1986) }\end{array}$ \\
\hline & $\begin{array}{l}\text { Southern Indian } \\
\text { Ocean }\end{array}$ & $1(\mathrm{p})$ & Adult & & 6.12 & & MBC & $\begin{array}{l}\text { Färber-Lorda } \\
\text { (1986) }\end{array}$ \\
\hline & $\begin{array}{l}\text { Southern Indian } \\
\text { Ocean }\end{array}$ & $1(\mathrm{p})$ & Juvenile & & 4.76 & & $\mathrm{MBC}$ & $\begin{array}{l}\text { Färber-Lorda } \\
\text { (1986) }\end{array}$ \\
\hline & $\begin{array}{l}\text { Southern Indian } \\
\text { Ocean }\end{array}$ & $1(\mathrm{p})$ & Juvenile & & 5.35 & & MBC & $\begin{array}{l}\text { Färber-Lorda } \\
\text { (1986) }\end{array}$ \\
\hline & $\begin{array}{l}\text { Southern Indian } \\
\text { Ocean }\end{array}$ & & & 74.2 & 5.42 & 21.00 & $\mathrm{PC}$ & $\begin{array}{l}\text { Färber-Lorda } \\
\text { et al. (2009b) }\end{array}$ \\
\hline
\end{tabular}


Table 1 (continued)

\begin{tabular}{|c|c|c|c|c|c|c|c|c|}
\hline \multirow[t]{2}{*}{ Season } & \multirow[t]{2}{*}{ Location } & \multirow[t]{2}{*}{$n$} & \multirow[t]{2}{*}{ Stage } & \multirow{2}{*}{$\begin{array}{l}\text { Water } \\
\text { Content }(\%)\end{array}$} & \multicolumn{2}{|c|}{ Mean energy density } & \multirow[t]{2}{*}{ Method } & \multirow[t]{2}{*}{ Source } \\
\hline & & & & & $\mathrm{kJ} \mathrm{g}^{-1} \mathrm{WW}$ & $\mathrm{kJ} \mathrm{g}^{-1} \mathrm{DW}$ & & \\
\hline Autumn & Weddell Sea & $1(\mathrm{p})$ & & 70.4 & $5.04^{\mathrm{f}}$ & 17.02 & $\mathrm{PC}$ & $\begin{array}{l}\text { Torres et al. } \\
\text { (1994) }\end{array}$ \\
\hline Winter & Scotia Sea & $6(\mathrm{p})$ & & $76.9 \pm 1.2 \mathrm{SD}$ & $3.72^{\mathrm{f}}$ & 16.10 & $\mathrm{PC}$ & $\begin{array}{l}\text { Torres et al. } \\
\text { (1994) }\end{array}$ \\
\hline \multicolumn{9}{|c|}{ Euphausia crystallorophias } \\
\hline \multirow[t]{2}{*}{ Summer } & Ross Sea & $4(?)$ & Adult & & & 19.33 & $\mathrm{BC}$ & $\begin{array}{l}\text { Ainley et al. } \\
\text { (2003) }\end{array}$ \\
\hline & WAP & (p) & & & & $21.8 \pm 0.8 \mathrm{SE}$ & Calc & Ruck et al. (2014) \\
\hline \multirow[t]{2}{*}{ Autumn } & & & & 80.6 & 3.85 & 19.85 & $\mathrm{BC}$ & $\begin{array}{l}\text { Green and Gales } \\
\text { (1990) }\end{array}$ \\
\hline & & & & 71.7 & $6.45^{\mathrm{d}}$ & 22.79 & $\mathrm{BC}$ & $\begin{array}{l}\text { Green and Gales } \\
\text { (1990) }\end{array}$ \\
\hline \multicolumn{9}{|c|}{ Euphausia triacantha } \\
\hline Winter & Scotia Sea & $9(\mathrm{p})$ & & $76.1 \pm 3.6 \mathrm{SD}$ & $2.92^{\mathrm{f}}$ & 12.22 & $\mathrm{PC}$ & $\begin{array}{l}\text { Torres et al. } \\
\text { (1994) }\end{array}$ \\
\hline \multicolumn{9}{|c|}{ Euphausia frigida } \\
\hline Summer & $\begin{array}{l}\text { Southern Indian } \\
\text { Ocean }\end{array}$ & $1(\mathrm{p})$ & & & 4.62 & & $\mathrm{MBC}$ & $\begin{array}{l}\text { Färber-Lorda } \\
\text { (1986) }\end{array}$ \\
\hline
\end{tabular}

Method used for energy density estimates are bomb calorimetry (BC), micro-bomb calorimetry (MBC), proximate composition (PC) and are calculated using published equations from Färber-Lorda et al. (2009a; Calc). Energy densities given in italics represent values that were converted using information from the given sources. $n$ represents the number of samples measured. Where this expresses samples of pooled individuals, this is indicated with $(\mathrm{p})$

${ }^{a}$ Energy density calculated with an energetic value of $39.54 \mathrm{~kJ} \mathrm{~g}^{-1}$ AFDW $\left(9.45 \mathrm{kcal} \mathrm{g}^{-1}\right)$ for lipids

${ }^{\mathrm{b}} \mathrm{A}$ factor of 4.1864 was used to convert calories to joules

${ }^{\mathrm{c}}$ Energy density calculated excluding chitin

${ }^{\mathrm{d}}$ Sample taken from bird stomach contents, in which the energetic value is potentially overestimated due to water removal in stomach

${ }^{\mathrm{e}}$ From Barrera-Oro (2002)

${ }^{\mathrm{f}} \mathrm{A}$ factor of 4.19 was used to convert calories to joules

superba, differences in timing of the peak energetic value can be expected between species. The spawning season for $T$. macrura ranges from June to January with a peak from September to November (Haraldsson and Siegel 2014), while E. crystallorophias spawn in November/December (Pakhomov and Perissinotto 1996; Falk-Petersen et al. 2000). Both species use energy reserves accumulated in summer and autumn to overwinter and reproduce, which ensures that their larvae can feed on the spring phytoplankton blooms (Falk-Petersen et al. 2000; Vallet et al. 2011). Euphausia superba needs the spring and summer phytoplankton blooms for sexual maturations, mating and egg development (Cuzin-Roudy et al. 1999). Due to the lack of data, however, these differences in life cycles do not become clear in a seasonal variability of their energetic density. Regarding lipid contents, E. crystallorophias showed steady decrease of lipid content over winter and the following spawning period in spring. Lipid content increased again in late spring/summer which was found to coincide with elevated chlorophyll $a$ content in the water column (Clarke 1984). Larger sized individuals of $E$. triacantha showed a higher lipid level and lower water content than smaller sized individuals. Seasonal changes in composition suggests that this species combusts tissue during winter (Torres et al. 1994).

\section{Amphipods}

The 820 amphipod species recorded in the Southern Ocean occupy a very wide variety of ecological niches and have a large range of feeding strategies (Dauby et al. 2001; De Broyer et al. 2001; Dauby et al. 2003; Zeidler and De Broyer 2014). The amphipods can be divided in gammarid and hyperiid amphipods. The gammarid amphipods are mainly benthic with few pelagic species. Some gammarids, such as species from the genus Eusirus, have been found closely related to the sea-ice underside (Flores et al. 2011; David et al. 2017). The hyperiid amphipods are mainly pelagic and have been found to be important prey species for top predators such as several bird species (Ridoux 1994; Bocher et al. 2001). The swarming Themisto gaudichaudii occurs in high abundances in the sub-Antarctic and Antarctic regions (Kane 1966). 
The energy density of several amphipod species from the Weddell and Scotia Seas was estimated using proximate composition by Torres et al. (1994). The lowest value of $9.9 \mathrm{~kJ} \mathrm{~g}^{-1} \mathrm{DW}$, was from the gammarid amphipod Parandania boecki collected in winter (Table S2). This species also had the highest water content and is the deepest living. It has furthermore been found to have low lipid levels and to be feeding on coelenterates (Reinhardt and Van Vleet 1986). The highest energetic density of $18.2 \mathrm{~kJ} \mathrm{~g}^{-1} \mathrm{DW}$, was from the hyperiid amphipod Cyllopus lucasii collected in autumn (Torres et al. 1994). The relatively high energy density expressed in $\mathrm{kJ} \mathrm{g}^{-1} \mathrm{WW}$ is a result of the water content of $68.7 \%$ (of $\mathrm{WW}$ ), which is relatively low compared to that of other amphipods or euphausiids.

Both C. lucasii and Primno macropa showed a significant decline in energy density in winter compared to autumn (Torres et al. 1994). This could be a result of reproductive activity, but considering what is known about the timing of reproduction, most likely a result of lipid combustion. This was supported by an increase in water content with decreasing lipid content. Cyllopus lucasii furthermore showed significant variability in lipid content between regions (Torres et al. 1994). Themisto gaudichaudii had a very low energy density of $12.7 \mathrm{~kJ} \mathrm{~g}^{-1}$ DW during wintertime. It was suggested to be a result of reproductive activity, as their reproduction peak is in spring. Mayzaud and Boutoute (2015) found that $T$. gaudichaudii (females), which continues to feed carnivorously over winter, had a relatively stable lipid content year-round. A bomb calorimetry measurement of $T$. gaudichaudii yielded an average energy density of $22.1 \mathrm{~kJ} \mathrm{~g}^{-1}$ DW (Ciancio et al. 2007). Torres et al. (1994) suggested a mixed overwintering strategy for all examined hyperiid amphipods. The gammarid amphipods examined in Torres et al. (1994) are all deeper living species and a business-as-usual overwintering strategy was suggested.

An energy density of $22.3 \mathrm{~kJ} \mathrm{~g}^{-1}$ DW was found for the gammarid Eusirus microps during summer in the Lazarev Sea (PS89). Eusirus microps has been found in the surface of both open and ice-covered waters during summer (Flores et al. 2011) and winter (Flores et al. 2011; David et al. 2017). All energy density values of amphipods are listed in Table S2 of the electronic supplement.

\section{Other crustacea}

Energy density values of crustaceans of the orders Decapoda, Mysida and the class Ostracoda were also found in Donnelly et al. (1994) and Torres et al. (1994). Their energy densities, estimated using proximate composition, ranged from 19.0 to $25.3,18.2$ to 24.0 , and 7.1 to $11.7 \mathrm{~kJ} \mathrm{~g}^{-1} \mathrm{DW}$, respectively. The decapod Pasiphaea scotiae had a higher energy density in autumn compared to winter, while the opposite was found for the decapod Petalidium foliacium.
The species from Torres et al. (1994) are all deeper living animals, although ostracods have also been found in the under-ice surface (David et al. 2017). Recorded energy density measurements including, where possible, values expressed in $\mathrm{kJ} \mathrm{g}^{-1} \mathrm{WW}$ are listed in Table $\mathrm{S} 3$ of the electronic supplement.

\section{Fishes}

In general, there is a strong distinction between coastal and oceanic fish assemblages (Hubold 1991; Kock 1992). The families Myctophidae, Bathylagidae, Gonostomatidae and Paralepidae dominate the fish community of the Southern Ocean's oceanic waters (Kock 1992; Flores et al. 2008; Duhamel et al. 2014). The oceanic myctophids, or lanternfishes, dominate the meso- and bathypelagic zones in term of species richness, abundance and biomass (references in Duhamel et al. 2014). The cold waters of the Antarctic continental shelf and slope are dominated by the Nototheniidae (Eastman and Eakin 2000; Van de Putte 2008), which are mainly benthic or bentho-pelagic (La Mesa et al. 2004). Other families significantly contributing to the Southern Ocean fish fauna are the Liparidae, Zoarcidae and Macrouridae (Duhamel et al. 2014). The neritic species composition differs between the continental areas, SIZ and around the (sub-)Antarctic islands (Kock 1992). In some species, the larval stages have a different (vertical) distribution pattern than adult individuals of the same species (e.g. Hubold 1990).

The availability of previously unpublished data and data of individual fish kindly provided by colleague researchers, allows for a more detailed description and analysis of the energetic density of the nototheniid Pleuragramma antarctica, the myctophids Electrona antarctica, Gymnoscopelus braueri and the bathylagiid Bathylagus antarcticus.

\section{Pleuragramma antarctica}

The notothenoid Pleuragramma antarctica is the most abundant pelagic fish in the high Antarctic coastal regions, with an extended range to the South Shetland and South Orkney Islands (Eastman and Hubold 1999; La Mesa et al. 2004; Donnelly and Torres 2008; Van de Putte 2008). It is an important prey species for many fish species and (Eastman 1985) and top predators, including flying birds (Van Franeker et al. 2001), seals (Southwell et al. 2012 and references therein) and penguins (Ainley et al. 1998; Cherel and Kooyman 1998),

Reported and measured average energy density values of Pleuragramma antarctica ranged from 21.7 to $27.9 \mathrm{~kJ} \mathrm{~g}^{-1}$ DW (both summer Ross Sea). In East Antarctica, the energy density increased with age, from 21.8 to $25.5 \mathrm{~kJ} \mathrm{~g}^{-1} \mathrm{DW}$ in small $(52-95 \mathrm{~mm})$ and large, adult $(>105 \mathrm{~mm})$ individuals, 
respectively (Van de Putte et al. 2010). The water content showed an opposite trend and was higher in the younger group (87.9\%) compared to the older one $(70.2 \%$; Van de Putte et al. 2010). The energy density of juvenile fish showed a lot of variation, possibly attributed to variability in foraging success (Van de Putte et al. 2010). Therefore, despite differences between size classes, there was no (linear) relationship between size and energy density within the small group. An overview of recorded average energy density measurements of Pleuragramma antarctica including, where possible, values expressed in $\mathrm{kJ} \mathrm{g}^{-1} \mathrm{WW}$ can be found in Table 2 .

The relatively low energy density of young Pleuragramma antarctica could possibly be due to their small size. The energy density of adult Pleuragramma antarctica is closer to that of the myctophid fishes, and evidence suggest that the energy density of adults would be even higher in fully grown individuals (Van de Putte et al. 2010). This suggestion is supported by a relatively high energetic density of larger fish from the Ross Sea (Lenky et al. 2012). This increased energy density could be a result of increased lipid content, which increases with age and size. This increase is suggested to be needed for buoyancy, to compensate for increasing weight, rather than an energy storage, as it is assumed that sufficient copepod and euphausiid prey are available for Pleuragramma antarctica year-round, and because large lipid stores were still found in this fish after winter (Gon and Heemstra 1990; Friedrich and Hagen 1994; Hubold and Hagen 1997). However, there is also evidence that Pleuragramma antarctica is cannibalistic from a study conducted in late spring (Eastman 1985). The difference in energy density between juvenile and adult fish can also be explained by the higher investment in protein growth rather that lipid accumulation, which is a common phenomenon in fish (Shul'man 1974). No data on energy density are available for the spawning season, presumably occurring in winter and spring, with a possible extended season into December in the Ross Sea (Vacchi et al. 2004).

\section{Other nototheniidae}

High energy densities of 29.9 and $29.4 \mathrm{~kJ} \mathrm{~g}^{-1}$ DW were reported for Dissostichus mawsoni (Antarctic toothfish) and Dissostichus eleginoides (Patagonian toothfish), respectively (Durand and Nicolle 1980; Lenky et al. 2012). Dissostichus mawsoni occurs mainly in high Antarctic waters. Dissostichus eleginoides is more distributed in the northern parts of the Southern Ocean, particularly around the sub-Antarctic islands, and around the southern tip of South America (Duhamel et al. 2014). A significant proportion of the diets of Dissostichus spp. consist of other fish (Kock 1992). Dissostichus spp. is of great commercial interest and is harvested using longlines. All notothenioids lack a swim bladder. Most species are




heavier than sea water, but still relatively light in weight compared to other teleosts (Eastman and DeVries 1982). Together with Pleuragramma antarctica and likely Aethotaxis mitopteryx, D. mawsoni accumulates lipids to achieve neutral buoyancy (Eastman and DeVries 1982; Kock 1992; Lenky et al. 2012). Juvenile D. mawsoni gradually becomes more buoyant with increasing size until they reach neutral buoyancy with adulthood at an approximate length of $81 \mathrm{~cm} \mathrm{SL}$ (Near et al. 2003).

The energy density of other nototheniid species found in the literature ranged from $18.6 \mathrm{~kJ} \mathrm{~g}^{-1} \mathrm{DW}$ for Trematomus scotti to $26.8 \mathrm{~kJ} \mathrm{~g}^{-1}$ DW for Trematomus lepidorhinus (proximate composition, Lenky et al. 2012), both caught in the Ross Sea during summer. Of the species listed in Lenky et al. (2012), Lepidonotothen squamifrons, Trematomus bernacchii, Trematomus hansoni, Trematomus pennelli and T. scotti are benthic species (Eastman and DeVries 1982; Lenky et al. 2012). Therefore, they are suggested to have less lipids and a higher proportion of ash (Hagen et al. 2000; Lenky et al. 2012). Furthermore Trematomus spp., Notothenia coriiceps and Gobionotothen gibberifrons mainly feed on benthic organisms which can have a relatively low energetic value such as polychaetes, molluscs and amphipods (Kock 1992; Lenky et al. 2012). Trematomus lepidorhinus feeds away from the bottom and possibly has more fat to increase buoyancy, explaining its higher energetic density (Lenky et al. 2012), although $L$. squamifrons has also been suggested to feed on both benthic and pelagic organisms (Kock 1992). Similar to Pleuragramma antarctica, the lipid content of T. lepidorhinus is known to increase with increasing size and weight (Friedrich and Hagen 1994).

Champsocephalus gunnari and Chaenocephalus aceratus have a northerly distribution usually occurring close to the APF, while the distribution of Channichthys spp. is limited to the Kerguelen Plateau (Duhamel et al. 2014). These species have similar energetic densities while they utilize different food sources (Kock 1992). An overview of recorded average energy density measurements of nototheniid fish species including, where possible, values expressed in $\mathrm{kJ} \mathrm{g}^{-1} \mathrm{WW}$ can be found in Table 3. Due to recent changes in the classification, former separate families are now included in the family Nototheniidae and the new proposed sub-families of the fish are given in brackets in the table (Duhamel et al. 2014). The energy densities of gonad, liver and muscle tissue of several nototheniid fish were measured separately using bomb calorimetry by Vanella et al. (2005). In most investigated species, the AFDW energy densities were highest in the liver (Vanella et al. 2005).

\section{Electrona antarctica}

Electrona antarctica is a circumpolar, widely distributed mesopelagic species found at and south of the APF (Duhamel et al. 2014). It has been found to be an important prey species for flying birds in the Weddell and Scotia Seas (Ainley et al. 1991). Records of the average energy density of $E$. antarctica showed a range between $18.9 \mathrm{~kJ} \mathrm{~g}^{-1} \mathrm{DW}$, for fish from the Scotia Sea during spring (proximate composition, Donnelly et al. 1990), and $34.3 \mathrm{~kJ} \mathrm{~g}^{-1} \mathrm{DW}$, for fish from the Kerguelen plateau during winter (bomb calorimetry; Lea et al. 2002). The lower range of values found in the literature were usually estimates made using proximate composition. Average recorded energy density measurements of $E$. antarctica including, where possible, values expressed in $\mathrm{kJ} \mathrm{g}^{-1}$ WW are listed in Table 4.

The energy content of E. antarctica generally increased with increasing size (Donnelly et al. 1990; Van de Putte et al. 2006, 2010). Van de Putte et al. (2006) showed that the energy density of $E$. antarctica strongly increased with size in age class 0 , and slows down from the second year onward while the variation increases. This trend is confirmed in fish from East Antarctica and the Lazarev Sea in several seasons (Fig. 2a). This size-energy density relationship suggests that the small fish invest more of their energy in growth compared to the older individuals, probably due to the need to grow quickly to avoid predation (Van de Putte et al. 2006).

Donnelly et al. (1990) found an increase in lipid and energy content from spring to autumn, and from autumn to winter (Table 4), and suggested that this might be due to the accumulation of reserves for winter and early spring. In contrast, however, the data from the Lazarev Sea suggest highest energy densities in summer, decreasing towards autumn and winter. In general, energy density of E. antarctica was higher in the Lazarev Sea compared to East Antarctica and Macquarie Island (Fig. 2a). Available measurements of individual fish, depicted in Fig. 2, allowed for a statistical comparison. The energy density of fish from the Lazarev Sea in summer was significantly higher than all other data (ANOVA $F(24,254)=36.8, p<0.001$; Tukey's HSD, $p<0.0001$ ), while the energy density of fish caught in East Antarctica in autumn was significantly lower than all other locations (Tukey's HSD, $p<0.03$ ). Based on current available science, E. antarctica is assumed to spawn year-round with a peak in late summer/early autumn, or late spring/summer (Donnelly et al. 1990). In contrast, Gon and Heemstra (1990) suggested a peak spawning season in autumn/winter. However, the energetic content of maturing gonads does not appear to contribute significantly to the total energy content of the fish (Donnelly et al. 1990). Therefore, the main driver for differences in energy density is probably food composition, which differs for E. antarctica depending on area and season (Flores et al. 2008). The relationship between DW 
Table 3 Overview of the average energy density of several nototheniid species

\begin{tabular}{|c|c|c|c|c|c|c|c|c|}
\hline \multirow[t]{2}{*}{ Season } & \multirow[t]{2}{*}{ Location } & \multirow[t]{2}{*}{$n$} & \multirow[t]{2}{*}{ Mean size $(\mathrm{mm})$} & \multirow{2}{*}{$\begin{array}{l}\text { Water content (\% } \\
\text { WW) }\end{array}$} & \multicolumn{2}{|c|}{ Mean energy density } & \multirow[t]{2}{*}{ Method } & \multirow[t]{2}{*}{ Source } \\
\hline & & & & & $\mathrm{kJ} \mathrm{g}^{-1} \mathrm{WW}$ & $\mathrm{kJ} \mathrm{g}^{-1} \mathrm{DW}$ & & \\
\hline \multicolumn{9}{|c|}{ Champsocephalus gunnari (Channichthyinae) } \\
\hline \multirow[t]{2}{*}{ Autumn } & Kerguelen & & $3311.7 \pm 16.1 \mathrm{SD}$ & $76.7 \pm 2.0 \mathrm{SD}$ & $5.4 \pm 0.3 \mathrm{SD}$ & $23.2 \pm 0.6 \mathrm{SD}$ & $\mathrm{BC}$ & Lea et al. (2002) \\
\hline & Scotia Sea & & $3437^{\mathrm{a}} \pm 15 \mathrm{SD}$ & $81.0 \pm 0.4 \mathrm{SE}$ & 4.65 & 24.74 & $\mathrm{PC}^{\mathrm{b}, \mathrm{c}}$ & Oehlenschläger (1991) \\
\hline Spring/summer & Kerguelen & & & 80.1 & 4.74 & 23.84 & $\mathrm{PC}^{\mathrm{c}}$ & $\begin{array}{l}\text { Durand and Nicolle } \\
\text { (1980) }\end{array}$ \\
\hline \multicolumn{9}{|c|}{ Chaenocephalus aceratus (Channichthyinae) } \\
\hline Autumn & Scotia Sea & & $10497^{\mathrm{a}} \pm 34 \mathrm{SD}$ & $81.2 \pm 0.8 \mathrm{SE}$ & 4.56 & 24.24 & $\mathrm{PC}^{\mathrm{b}, \mathrm{c}}$ & Oehlenschläger (1991) \\
\hline \multicolumn{9}{|c|}{ Channichthys rhinoceratus (Channichthyinae) } \\
\hline Spring & Kerguelen & & & 82.8 & 3.97 & 23.09 & $\mathrm{PC}^{\mathrm{c}}$ & $\begin{array}{l}\text { Durand and Nicolle } \\
\text { (1980) }\end{array}$ \\
\hline \multicolumn{9}{|c|}{ Dissostichus mawsoni (Dissostichinae) } \\
\hline Spring & McMurdo & & 1 & 68.6 & 9.4 & 29.94 & $\mathrm{BC}$ & Lenky et al. (2012) \\
\hline \multicolumn{9}{|c|}{ Dissostichus eleginoides (Dissostichinae) } \\
\hline Spring/summer & Kerguelen & & & 69.4 & 9.00 & 29.42 & $\mathrm{PC}^{\mathrm{c}}$ & $\begin{array}{l}\text { Durand and Nicolle } \\
\text { (1980) }\end{array}$ \\
\hline \multicolumn{9}{|c|}{ Pagothenia borchgrevinki (Trematominae) } \\
\hline \multirow[t]{3}{*}{ Spring } & McMurdo 2006 & $1(\mathrm{p})$ & $182^{\mathrm{a}} \pm 3 \mathrm{SE}$ & 77.2 & 5.6 & 24.56 & $\mathrm{BC}$ & Lenky et al. (2012) \\
\hline & McMurdo 2006 & & $4205^{\mathrm{a}} \pm 26 \mathrm{SE}$ & $77.6 \pm 3.1 \mathrm{SE}$ & $5.3 \pm 1.3 \mathrm{SE}$ & 23.66 & $\mathrm{BC}$ & Lenky et al. (2012) \\
\hline & McMurdo 2007 & & $4235^{\mathrm{a}} \pm 27 \mathrm{SE}$ & $76.0 \pm 2.5 \mathrm{SE}$ & $5.7 \pm 1.1 \mathrm{SE}$ & 23.75 & $\mathrm{BC}$ & Lenky et al. (2012) \\
\hline \multicolumn{9}{|c|}{ Trematomus bernacchii (Trematominae) } \\
\hline \multirow[t]{3}{*}{ Spring } & McMurdo 2006 & (p) & $146^{\mathrm{a}} \pm 18 \mathrm{SE}$ & 78.3 & 4.7 & 21.66 & $\mathrm{BC}$ & Lenky et al. (2012) \\
\hline & McMurdo 2007 & (p) & $164^{\mathrm{a}} \pm 25 \mathrm{SE}$ & 77.4 & 5.0 & 22.12 & $\mathrm{BC}$ & Lenky et al. (2012) \\
\hline & McMurdo 2007 & & $4189^{\mathrm{a}} \pm 22 \mathrm{SE}$ & $76.2 \pm 3.0 \mathrm{SE}$ & $5.5 \pm 1.3 \mathrm{SE}$ & 23.11 & $\mathrm{BC}$ & Lenky et al. (2012) \\
\hline \multicolumn{9}{|c|}{ Trematomus hansoni (Trematominae) } \\
\hline Spring & McMurdo Sound & & $7211^{\mathrm{a}} \pm 262 \mathrm{SE}$ & $76.7 \pm 2.0 \mathrm{SE}$ & $5.4 \pm 0.9 \mathrm{SE}$ & 23.18 & $\mathrm{BC}$ & Lenky et al. (2012) \\
\hline \multicolumn{9}{|c|}{ Trematomus pennellii (Trematominae) } \\
\hline Spring & McMurdo Sound & $1(\mathrm{p})$ & $141^{\mathrm{a}} \pm 16 \mathrm{SE}$ & 78.3 & 4.6 & 21.20 & $\mathrm{BC}$ & Lenky et al. (2012) \\
\hline \multicolumn{9}{|c|}{ Trematomus eulepidotus (Trematominae) } \\
\hline Summer & Ross Sea & (p) & $196^{\mathrm{a}} \pm 31 \mathrm{SE}$ & 75.6 & 5.7 & 23.36 & $\mathrm{BC}$ & Lenky et al. (2012) \\
\hline \multicolumn{9}{|c|}{ Trematomus lepidorhinus (Trematominae) } \\
\hline Summer & Ross Sea & (p) & $274^{\mathrm{a}} \pm 56 \mathrm{SE}$ & 71.3 & 7.7 & 26.83 & $\mathrm{BC}$ & Lenky et al. (2012) \\
\hline \multicolumn{9}{|c|}{ Trematomus scotti (Trematominae) } \\
\hline Summer & Ross Sea & (p) & $129^{\mathrm{a}} \pm 7 \mathrm{SE}$ & 78.5 & 4.0 & 18.60 & $\mathrm{BC}$ & Lenky et al. (2012) \\
\hline \multicolumn{9}{|c|}{ Lepidonotothen squamifrons (Trematominae) } \\
\hline Summer & Ross Sea & (p) & $224^{\mathrm{a}} \pm 317 \mathrm{SE}$ & 81.3 & 4.0 & 21.39 & $\mathrm{BC}$ & Lenky et al. (2012) \\
\hline Spring/summer & Kerguelen & & & 79.8 & 4.78 & 23.67 & $\mathrm{PC}^{\mathrm{c}}$ & $\begin{array}{l}\text { Durand and Nicolle } \\
\text { (1980) }\end{array}$ \\
\hline & & & & & 5.00 & & & $\begin{array}{l}\text { Goldsworthy et al. } \\
\text { (2001) }\end{array}$ \\
\hline Notothenia rossi ( & ototheniinae) & & & & & & & \\
\hline Spring & Kerguelen & & & 76.7 & 6.07 & 26.07 & $\mathrm{PC}^{\mathrm{c}}$ & $\begin{array}{l}\text { Durand and Nicolle } \\
\text { (1980) }\end{array}$ \\
\hline Notothenia neglec & (Nototheniinae) & & & & & & & \\
\hline Autumn & Scotia Sea & & $3317^{\mathrm{a}} \pm 51 \mathrm{SD}$ & $78.4 \pm 1.0 \mathrm{SE}$ & 5.35 & 24.77 & $\mathrm{PC}^{\mathrm{b}, \mathrm{c}}$ & Oehlenschläger (1991) \\
\hline Gobionotothen gil & erifrons (Gobinotot & ninae) & & & & & & \\
\hline Autumn & Scotia Sea & & $13377^{\mathrm{a}} \pm 17 \mathrm{SD}$ & $79.8 \pm 0.4 \mathrm{SE}$ & 4.85 & 24.05 & $\mathrm{PC}^{\mathrm{b}, \mathrm{c}}$ & Oehlenschläger (1991) \\
\hline
\end{tabular}

Sub-families are given in brackets. Energy densities were measured using bomb calorimetry (BC) and proximate composition (PC). Energy densities in italics represent values that were converted using information from the given sources. $n$ represents the number of samples measured. Where this expresses samples of pooled individuals, this is indicated with (p). The standard error (SE) or standard deviation (SD) as given in the original source is added where available $( \pm)$. The mean size is given in standard length (SL) unless otherwise indicated

${ }^{a}$ Measured in total length (TL)

${ }^{\mathrm{b}}$ Crude protein measurement used

${ }^{3}$ Carbohydrates not measured 


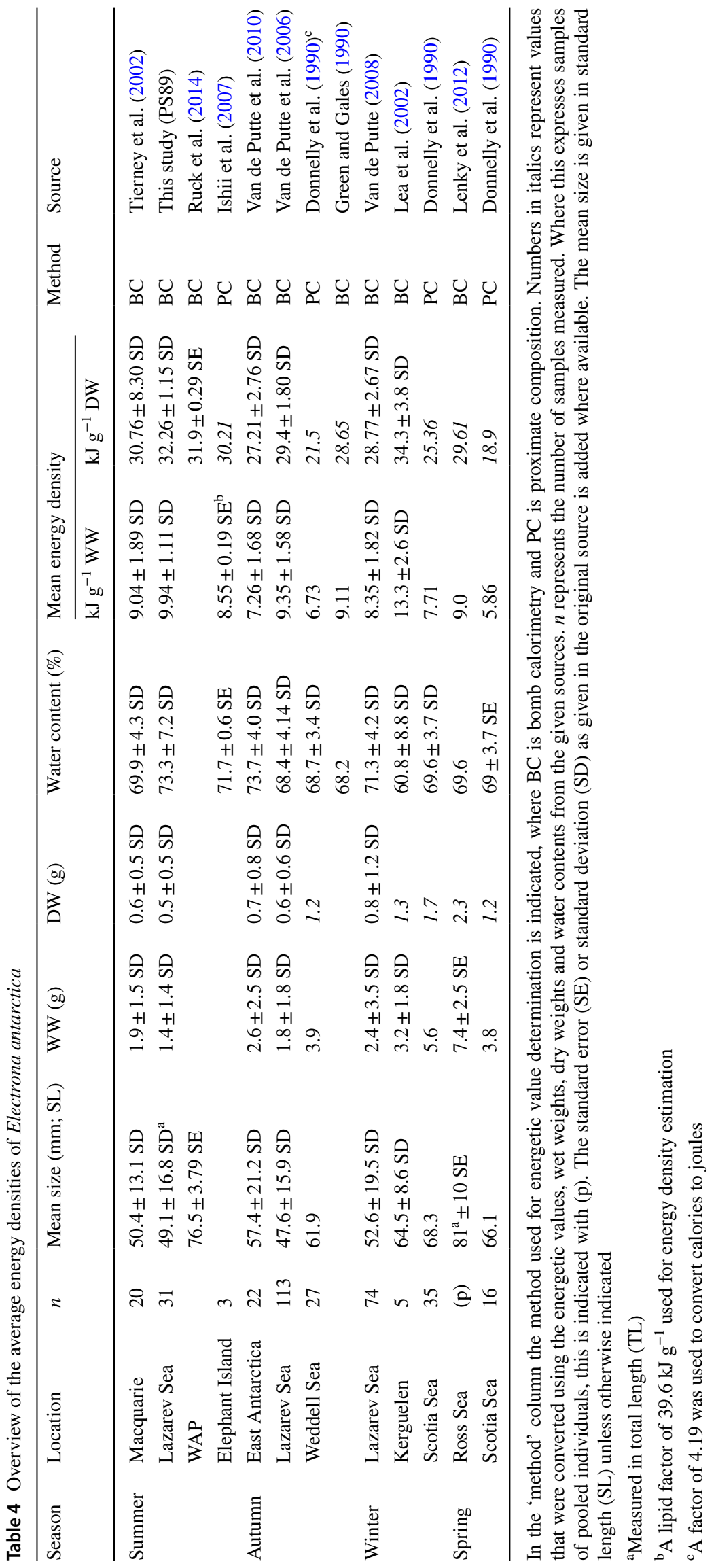




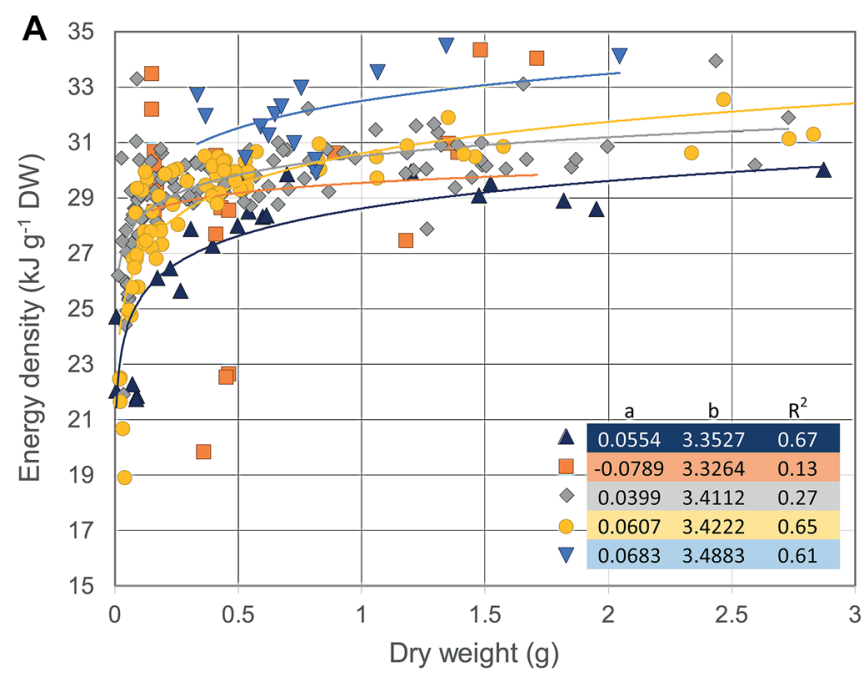

Fig. 2 Electrona antarctica; a the relationship between dry weight (DW) and energy density $\mathrm{g}^{-1}$ DW including the parameters for the linear regression of $\ln (y)=a+b \ln (x)$, and the corresponding power function $y=x^{b} \quad e^{a}$ and, $\mathbf{b}$ the relationship between DW (\%WW) and energy density $\mathrm{g}^{-1}$ wet weight (WW) including regression parameters of the linear regression lines $y=a x+b$. Regression parameters are depicted in the figures. Data were obtained from Tierney et al. (2002)

(in \% $\mathrm{WW}$ ) and wet weight energy density was similar in fish from all seasons and regions (ANCOVA, $p>0.05$; Fig. 2b).

\section{Gymnoscopelus braueri}

Gymnoscopelus braueri is also a circumpolar, widely distributed species found between de SAF and the SACCF (Duhamel et al. 2014). Recorded average energy densities of G. braueri ranged from $19.9 \mathrm{~kJ} \mathrm{~g}^{-1} \mathrm{DW}$ in fish from the Scotia Sea during spring (proximate composition, Donnelly et al. 1990) to $39.0 \mathrm{~kJ} \mathrm{~g}^{-1}$ DW in fish from the vicinity of Macquarie Island during summer (bomb calorimetry, Tierney et al. 2002). An overview of recorded average energy density measurements of $G$. braueri including, where possible, values expressed in $\mathrm{kJ} \mathrm{g}^{-1} \mathrm{WW}$ can be found in Table 5 .

Tierney et al. (2002) found a strong difference in calorific value between size classes in summer. Fish $<40 \mathrm{~mm}$ had a significantly higher dry weight energy density compared to larger individuals, which is in contrast to E. antarctica. Interestingly, the small fish also had a significantly higher water content (Tierney et al. 2002). This pattern was, however, not confirmed by data from the Lazarev Sea in autumn where the dry-weight energy density did not differ in different sized fish (Van de Putte et al. 2006). Within the size classes found in Tierney et al. (2002), there was no (linear) relationship between size and dry-weight energy density (Fig. 3a). The data from Macquarie Island (Tierney et al. 2002) and the Lazarev Sea (Van de Putte et al. 2006 and PS81) allowed for statistical comparison, which showed that

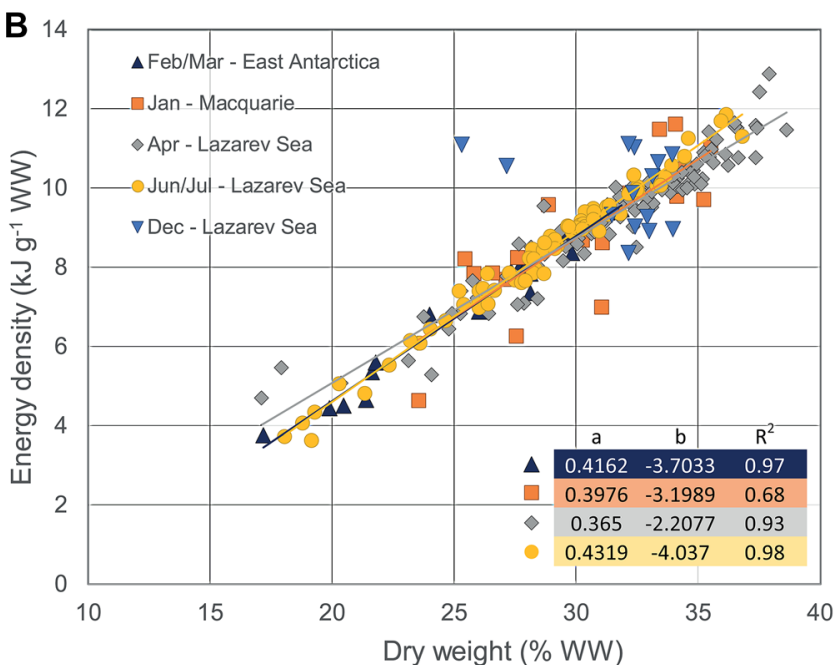

(Macquarie Island), Van de Putte et al. (2010) (East Antarctica, February-March), Van de Putte et al. (2006) (Lazarev Sea, April), Van de Putte 2008 (Lazarev Sea, June/July) or collected during PS89 (Lazarev Sea, December). All measurements were done using bomb calorimetry. The legend, depicted in $\mathrm{B}$, indicates month and location of data collection. No regression was fitted for the December-Lazarev Sea data in $\mathbf{b}$, due to two individuals that had divergent dry weights

the energy density of $G$. braueri $>40 \mathrm{~mm}$ did not vary significantly between seasons and regions, even in the relatively small fish from winter (ANOVA, $F(3,35)=0.288, p=0.83$ ).

In fish $>40 \mathrm{~mm}$, the relationship between water content and wet-weight energy density of G. braueri from the Lazerev Sea in April and the Macquarie region in January show similar slopes (Fig. 3b) suggesting that there is no evidence that tissues replacing the body water are markedly different between seasons and/or regions (ANCOVA, $p>0.05$ ). As the small fish from the Macquarie region have a relatively high energy density, the intercept of this regression is significantly higher compared to regressions of the other data (ANCOVA, $p<0.05$ ).

\section{Other myctophids}

The average energy density of other myctophid species reported in the literature range from $17.1 \mathrm{~kJ} \mathrm{~g}^{-1} \mathrm{DW}$ of Protomyctophum tenisoni and Protomyctophum bolini caught in the Scotia Sea during winter (proximate composition, Donnelly et al. 1990) to $39.3 \mathrm{~kJ} \mathrm{~g}^{-1}$ DW of Protomyctophum andriashevi caught in the vicinity of Macquarie Island during summer (bomb calorimetry, Tierney et al. 2002). Similar to G. braueri, Tierney et al. (2002) found several, but not all, other myctophid species in which small individuals ( $<40 \mathrm{~mm}$ SL, approximately) had a significantly higher dry-weight energy density such as Gymnoscopelus fraseri, $P$. andriashevi, P. bolini and Lampanyctus archirus. In contrast to the other species, the water content of $G$. fraseri 


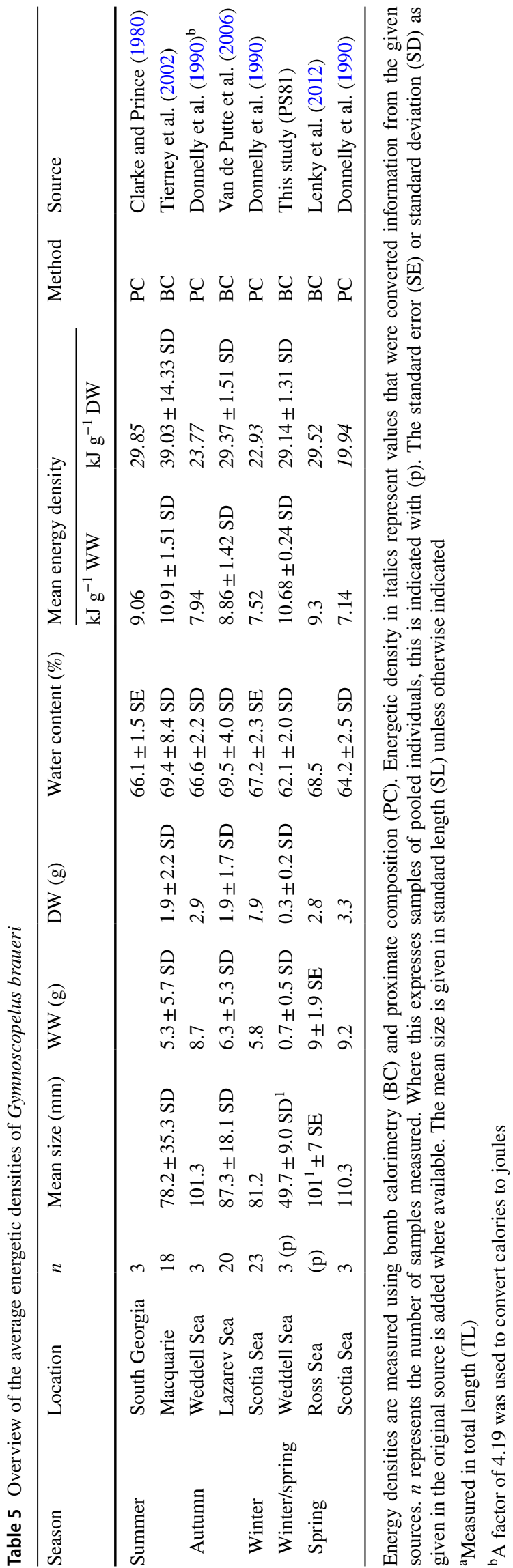

and $P$ andriashevi did not differ significantly between size classes (Tierney et al. 2002). An overview of recorded average energy density measurements of myctophid fish species including, where possible, values expressed in $\mathrm{kJ} \mathrm{g}^{-1} \mathrm{WW}$ is listed in Table 6.

Of the species listed, P. tenisoni, Electrona carlsbergi, G. fraseri and Gymnoscopelus piabilis occur mainly in the sub-Antarctic zone, while the other species occur south of the PF or have a more wide distribution. Protomyctophum tenisoni, E. carlsbergi, Gymnoscopelus ophistopterus, and Gymnoscopelus microlampas have relatively low energy densities considering what can be assumed for lipid-rich myctophid species. Lea et al. (2002) found that P. tenisoni had a relatively low lipid content compared to other investigated myctophid fishes. Electrona carlsbergi was, however, lipid-rich in this study (Lea et al. 2002).

\section{Bathylagus antarcticus}

Of the two main species of Bathylagidae (Bathylagus tenuis and Bathylagus antarcticus) found in the meso- and bathypelagic zones of the Southern Ocean, B. antarcticus has the more southern distribution (Duhamel et al. 2014). Recorded average energy densities of $B$. antarcticus ranged from $14.8 \mathrm{~kJ} \mathrm{~g}^{-1} \mathrm{DW}$, estimated in fish from the winter Scotia sea using proximate composition (Donnelly et al. 1990), to $22.8 \mathrm{~kJ} \mathrm{~g}^{-1} \mathrm{DW}$ measured in fish from the spring Ross Sea using bomb calorimetry (Lenky et al. 2012). Average recorded energy density measurements of $B$. antarcticus including, where possible, values expressed in $\mathrm{kJ} \mathrm{g}^{-1} \mathrm{WW}$ are listed in Table 7.

The dry-weight energy density of $B$. antarcticus caught in the Lazarev Sea in April (Van de Putte et al. 2006) did not differ significantly from fish caught in the vicinity of Macquarie Island in January (Tierney et al. 2002), even though the latter fish were larger (Fig. 4a). In both seasons/regions, the energy density did not change with changing sizes. Water content of $B$. antarcticus was significantly higher in April than it was in January, resulting in a lower wet weight energy density in the Lazarev Sea in April compared to the Macquarie region in January. The relationship between wetweight energy density and proportional dry-weight found by Van de Putte et al. (2006) suggested that water is replaced with low energy tissue. This relationship is, however, different in the fish from Tierney et al. (2002), where energy density is relatively low compared to other fish species from the same study, but the wet-weight energy density increases relatively fast with decreasing water content (Fig. 4b).

\section{Other fishes}

An overview of recorded average energy density measurements of five fish species other than the ones listed above 


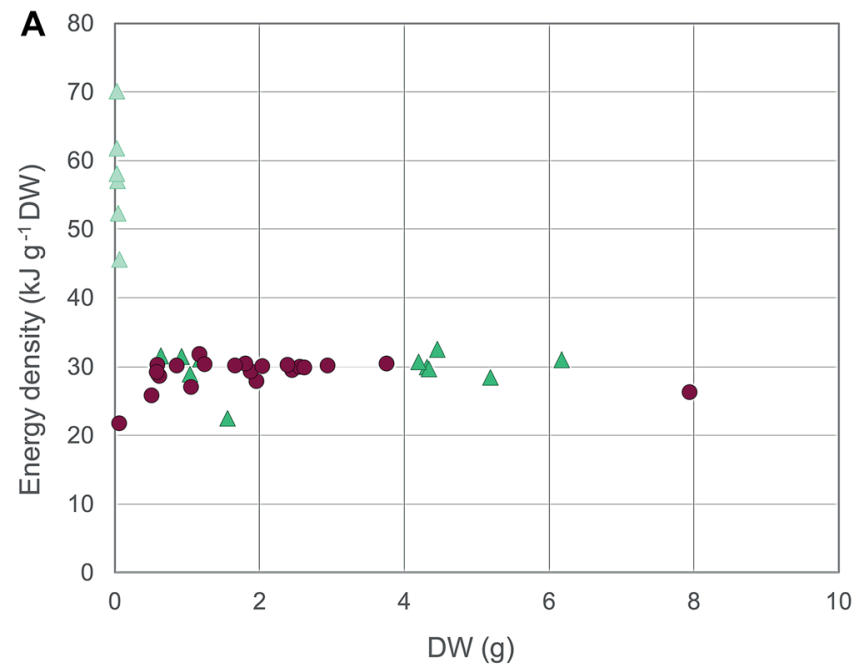

Fig. 3 Gymnoscopelus braueri; a the relationship between dry weight (DW) and energy density $\mathrm{g}^{-1}$ DW and, b the relationship between DW (\%WW) and energy density $\mathrm{g}^{-1}$ wet weight (WW) including parameters of the linear regression lines $y=a x+b$. Regression parameters are depicted in the figure. Data were obtained from Tierney et al. (2002) (Macquarie Island, January) and Van de Putte

including, where possible, values expressed in $\mathrm{kJ} \mathrm{g}^{-1} \mathrm{WW}$ can be found in Table 8. The families to which the species belong are given in the table. Among these fishes, Paradiplospinus gracilis had the highest mean energy density of $25.6 \mathrm{~kJ} \mathrm{~g}^{-1} \mathrm{DW}$. The lowest values were found in Notolepis coatsi from autumn and winter in the Weddell-Scotia Seas sector (14.9 and $15.6 \mathrm{~kJ} \mathrm{~g}^{-1} \mathrm{DW}$, respectively). Both measurements were done using proximate composition. Ciancio et al. (2007) list another nine species of which the distribution in the Southern Ocean is limited to the Patagonian shelf. Their energy density (measured using bomb calorimetry) ranged from $16.2 \mathrm{~kJ} \mathrm{~g}^{-1} \mathrm{DW}$ for Genypterus blacodes (Ophidiidae) to $26.2 \mathrm{~kJ} \mathrm{~g}^{-1} \mathrm{DW}$ for Eleginops maclovinus (Eleginopidae; Ciancio et al. 2007).

\section{Other species}

\section{Squid}

Squid are often a part of, or even dominate in some seasons, the diet of many top predators (Klages 1989; Ainley et al. 1991; Cherel et al. 1996; Kirkman et al. 2000; Van Franeker et al. 2001). Therefore, an indication of their energy density is highly relevant in trophic and ecosystem studies. Although measurements of squid are limited, reported values suggest that the energy density of squid increases with increasing latitudes (from the tropics to Southern Ocean), and that the energy density of squid in the Southern Ocean is comparable with that of nototheniid

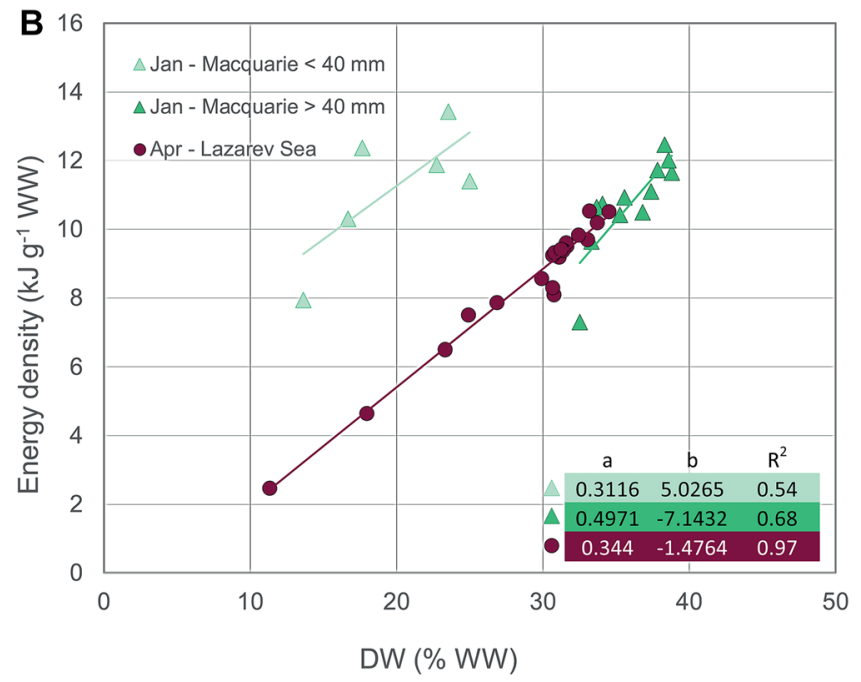

et al. (2006) (Lazarev Sea, April). Due to significant differences in energetic density, data from Tierney et al. (2002) were separated in individuals $<40$ and $>40 \mathrm{~mm}$. All measurements were done using bomb calorimetry. Legend indicates month and location of data collection

fish. Squid are difficult to catch with scientific sampling gear (Rodhouse et al. 2014), explaining the limited amount of measurements on this group (Table 9). Therefore, we have included some energetic density measurements from regions other than the Southern Ocean in this section for comparison.

Croxall and Prince (1982) provide an overview of energy densities of cephalopods from different locations. The reported values ranged from 14.9 to $19.9 \mathrm{~kJ} \mathrm{~g}^{-1} \mathrm{DW}$. The cephalopods listed in Croxall and Prince (1982) belong to the families Loliginidae, Octopodidae, Ommastrephidae, Onychoteuthidae and Sepiidae. Of the reported species, only the squid Doryteuthis gahi occurs south of the STF, over the Patagonian shelf in the sub-Antarctic region (Rodhouse et al. 2014). It had an energy density of $16.2 \mathrm{~kJ} \mathrm{~g}^{-1} \mathrm{DW}$ (Ferreyra in Pandit and Magar 1972). Ciancio et al. (2007) reported an energy density of $21.2 \mathrm{~kJ} \mathrm{~g}^{-1} \mathrm{DW}$ for $D$. gahi. They, furthermore, reported the energy density of Illex argentinus, also caught over the Patagonian shelf (Table 9; Ciancio et al. 2007).

Moroteuthis ingens is a very abundant species in the Southern Ocean. The mantle and tentacles of $M$. ingens, collected from the stomach contents of king penguins (Aptenodytes patagonicus) at Possession Island in summer, had an energy density of $23.5 \mathrm{~kJ} \mathrm{~g}^{-1} \mathrm{DW}$, measured using bomb calorimetry (Cherel and Ridoux 1992). Proximate composition values of $M$. ingens caught near New Zealand (Vlieg 1984) result in an estimated energy density of $24.0 \mathrm{~kJ} \mathrm{~g}^{-1} \mathrm{DW}$. The mantle, fins and tentacles of M. ingens, 
Table 6 Overview of the average energy density of several myctophid species

\begin{tabular}{|c|c|c|c|c|c|c|c|c|}
\hline \multirow[t]{2}{*}{ Season } & \multirow[t]{2}{*}{ Location } & \multirow[t]{2}{*}{$n$} & \multirow[t]{2}{*}{ Size $(\mathrm{mm})$} & \multirow{2}{*}{$\begin{array}{l}\text { Water content (\% } \\
\text { WW) }\end{array}$} & \multicolumn{2}{|c|}{ Mean energetic density } & \multirow[t]{2}{*}{ Method } & \multirow[t]{2}{*}{ Source } \\
\hline & & & & & $\mathrm{kJ} \mathrm{g}^{-1} \mathrm{WW}$ & $\mathrm{kJ} \mathrm{g}^{-1} \mathrm{DW}$ & & \\
\hline \multicolumn{9}{|c|}{ Gymnoscopelus ophistopterus } \\
\hline Autumn & Weddell Sea & 6 & 108.8 & $80.1 \pm 3.3 \mathrm{SD}$ & 4.58 & 23.02 & $\mathrm{PC}$ & $\begin{array}{l}\text { Donnelly et al. } \\
1990^{\mathrm{d}}\end{array}$ \\
\hline \multicolumn{9}{|c|}{ Gymnoscopelus fraseri } \\
\hline Summer & Macquarie & $18(\mathrm{p})$ & $35-78$ & $73.1 \pm 4.0 \mathrm{SD}$ & 7.89 & $29.32 \pm 8.62 \mathrm{SD}$ & $\mathrm{BC}$ & Tierney et al. (2002) \\
\hline Winter & Kerguelen & 5 & $66.2 \pm 7.1 \mathrm{SD}$ & $62.6 \pm 10.1 \mathrm{SD}$ & $10.2 \pm 3.5 \mathrm{SD}$ & $27.0 \pm 2.9 \mathrm{SD}$ & $\mathrm{BC}$ & Lea et al. (2002) \\
\hline \multicolumn{9}{|c|}{ Gymnoscopelus piabilis } \\
\hline Winter & Kerguelen & 5 & $187.6 \pm 32.0 \mathrm{SD}$ & $68.5 \pm 3.0 \mathrm{SD}$ & $9.5 \pm 1.7 \mathrm{SD}$ & $30.0 \pm 30.0 \mathrm{SD}$ & $\mathrm{BC}$ & Lea et al. (2002) \\
\hline \multicolumn{9}{|c|}{ Gymnoscopelus nicholsi } \\
\hline Summer & Elephant Island & 3 & & $76.7 \pm 0.7 \mathrm{SE}$ & $5.82 \pm 0.22 \mathrm{SE}^{\mathrm{a}}$ & 24.98 & $\mathrm{PC}$ & Ishii et al. (2007) \\
\hline \multirow[t]{2}{*}{ Autumn } & & & & 67 & 8.43 & 25.55 & $\mathrm{PC}$ & VNIRO (2000) \\
\hline & & & & 66.4 & 9.58 & 28.51 & $\mathrm{BC}$ & $\begin{array}{l}\text { Green and Gales } \\
(1990\end{array}$ \\
\hline \multirow[t]{2}{*}{ Winter } & Kerguelen & 1 & 128 & 66.8 & 9.80 & 28.00 & $\mathrm{BC}$ & Lea et al. (2002) \\
\hline & Scotia Sea & 1 & 148 & 59.6 & 11.75 & 29.08 & $\mathrm{PC}$ & $\begin{array}{l}\text { Donnelly et al. } \\
\text { (1990) }\end{array}$ \\
\hline Spring & Ross Sea & (p) & $149^{\mathrm{b}} \pm 7 \mathrm{SE}$ & 64.9 & 10.3 & 29.34 & $\mathrm{BC}$ & Lenky et al. (2012) \\
\hline \multicolumn{9}{|c|}{ Gymnoscopelus microlampas } \\
\hline Summer & Macquarie & $6(\mathrm{p})$ & $84-122$ & $74.7 \pm 1.3 \mathrm{SD}$ & 5.72 & $22.62 \pm 1.14 \mathrm{SD}$ & $\mathrm{BC}$ & Tierney et al. (2002) \\
\hline \multicolumn{9}{|c|}{ Electrona subaspera } \\
\hline Summer & Macquarie & $6(\mathrm{p})$ & $10-117$ & $72.1 \pm 1.7 \mathrm{SD}$ & 7.41 & $26.56 \pm 1.15 \mathrm{SD}$ & $\mathrm{BC}$ & Tierney et al. (2002) \\
\hline Winter & Kerguelen & 3 & $92.7 \pm 7.5 \mathrm{SD}$ & $72.3 \pm 1.6 \mathrm{SD}$ & $7.4 \pm 1.0 \mathrm{SD}$ & $26.6 \pm 2.1 \mathrm{SD}$ & $\mathrm{BC}$ & Lea et al. 2002 \\
\hline \multicolumn{9}{|c|}{ Electrona carlsbergi } \\
\hline \multirow[t]{5}{*}{ Summer } & South Georgia & 3 & & $71.2 \pm 0.3 \mathrm{SE}$ & 6.57 & 22.84 & $\mathrm{PC}$ & $\begin{array}{l}\text { Clarke and Prince } \\
\text { (1980) }\end{array}$ \\
\hline & & & & 72.7 & 5.87 & 21.50 & $\mathrm{PC}$ & VNIRO (2000) \\
\hline & Possession Island & 3 & $78.8 \pm 4.6 \mathrm{SD}$ & $70.2 \pm 0.4 \mathrm{SD}$ & $7.0 \pm 0.2 \mathrm{SD}^{\mathrm{c}}$ & $23.5 \pm 0.4 \mathrm{SD}^{\mathrm{c}}$ & $\mathrm{BC}$ & $\begin{array}{l}\text { Cherel and Ridoux } \\
\text { (1992) }\end{array}$ \\
\hline & Elephant Island & 3 & & $73.8 \pm 0.7 \mathrm{SE}$ & $6.92 \pm 0.13 \mathrm{SE}$ & 26.41 & $\mathrm{PC}$ & Ishii et al. (2007) \\
\hline & Macquarie & $6(\mathrm{p})$ & $26-97$ & $76.7 \pm 5.2 \mathrm{SD}$ & 5.05 & $21.67 \pm 3.17 \mathrm{SD}$ & $\mathrm{BC}$ & Tierney et al. (2002) \\
\hline Winter & Kerguelen & 6 & $84.7 \pm 3.6 \mathrm{SD}$ & $67.0 \pm 3.2 \mathrm{SD}$ & $8.6 \pm 1.2 \mathrm{SD}$ & $25.9 \pm 3.2 \mathrm{SD}$ & $\mathrm{BC}$ & Lea et al. (2002) \\
\hline Spring & Ross Sea & (p) & $72 \pm 6 \mathrm{SE}^{\mathrm{b}}$ & 73.9 & 6.1 & 23.37 & $\mathrm{BC}$ & Lenky et al. (2012) \\
\hline \multicolumn{9}{|c|}{ Krefftichthys anderssoni } \\
\hline \multirow[t]{2}{*}{ Summer } & Possession Island & 2 & $47.7 \pm 9.2 \mathrm{SD}$ & $69.3 \pm 1.4 \mathrm{SD}$ & $8.1 \pm 0.3 \mathrm{SD}^{\mathrm{c}}$ & $26.4 \pm 0.1 \mathrm{SD}^{\mathrm{c}}$ & $\mathrm{BC}$ & $\begin{array}{l}\text { Cherel and Ridoux } \\
\text { (1992) }\end{array}$ \\
\hline & Macquarie & $18(\mathrm{p})$ & $40-69$ & $69.8 \pm 1.9 \mathrm{SD}$ & 8.32 & $27.54 \pm 2.75 \mathrm{SD}$ & $\mathrm{BC}$ & Tierney et al. (2002) \\
\hline Autumn & & & & 66.6 & 10.12 & 30.30 & $\mathrm{BC}$ & $\begin{array}{l}\text { Green and Gales } \\
(1990)\end{array}$ \\
\hline \multicolumn{9}{|c|}{ Protomyctophum tenisoni } \\
\hline Summer & Macquarie & $6(p)$ & $43-51$ & $73.2 \pm 1.1 \mathrm{SD}$ & 5.50 & $20.53 \pm 0.65 \mathrm{SD}$ & $\mathrm{BC}$ & Tierney et al. (2002) \\
\hline \multirow[t]{2}{*}{ Winter } & Kerguelen & 1 & 45 & 74.6 & 6.1 & 24.2 & $\mathrm{BC}$ & Lea et al. (2002) \\
\hline & Scotia Sea & 3 & 47 & $72.2 \pm 0.6 \mathrm{SD}$ & 4.75 & 17.09 & $\mathrm{PC}$ & Donnelly et al. 1990 \\
\hline \multicolumn{9}{|c|}{ Protomyctophum andriashevi } \\
\hline Summer & Macquarie & $12(\mathrm{p})$ & $23-51$ & $75.7 \pm 5.3 \mathrm{SD}$ & 9.54 & $39.26 \pm 21.48 \mathrm{SD}$ & $\mathrm{BC}$ & Tierney et al. (2002) \\
\hline Protomycto & phum bolini & & & & & & & \\
\hline Summer & Macquarie & $18(\mathrm{p})$ & $29-61$ & $73.5 \pm 3.9 \mathrm{SD}$ & 7.42 & $28.00 \pm 10.61 \mathrm{SD}$ & $\mathrm{BC}$ & Tierney et al. (2002) \\
\hline Winter & Scotia Sea & 6 & 48.3 & $74.6 \pm 1.4 \mathrm{SD}$ & 4.34 & 17.09 & $\mathrm{PC}$ & $\begin{array}{l}\text { Donnelly et al. } \\
\text { (1990) }\end{array}$ \\
\hline Protomyctc & phum parallelum & & & & & & & \\
\hline Summer & Macquarie & $6(\mathrm{p})$ & $20-48$ & $70.9 \pm 3.6 \mathrm{SD}$ & 8.23 & $28.27 \pm 12.28 \mathrm{SD}$ & $\mathrm{BC}$ & Tierney et al. (2002) \\
\hline
\end{tabular}


Table 6 (continued)

\begin{tabular}{|c|c|c|c|c|c|c|c|c|}
\hline \multirow[t]{2}{*}{ Season } & \multirow[t]{2}{*}{ Location } & \multirow[t]{2}{*}{$n$} & \multirow[t]{2}{*}{ Size $(\mathrm{mm})$} & \multirow{2}{*}{$\begin{array}{l}\text { Water content (\% } \\
\text { WW) }\end{array}$} & \multicolumn{2}{|c|}{ Mean energetic density } & \multirow[t]{2}{*}{ Method } & \multirow[t]{2}{*}{ Source } \\
\hline & & & & & $\mathrm{kJ} \mathrm{g}^{-1} \mathrm{WW}$ & $\mathrm{kJ} \mathrm{g}^{-1} \mathrm{DW}$ & & \\
\hline \multicolumn{9}{|c|}{ Lampanyctus archirus } \\
\hline Summer & Macquarie & $18(\mathrm{p})$ & $35-147$ & $78.5 \pm 3.4 \mathrm{SD}$ & 6.12 & $28.47 \pm 14.43 \mathrm{SD}$ & $\mathrm{BC}$ & Tierney et al. (2002) \\
\hline
\end{tabular}

Energy density measurement were done using bomb calorimetry (BC) and proximate composition (PC). Energy densities in italics represent values that were converted using information from the given sources. $n$ represents the number of samples measured. Where this expresses samples of pooled individuals, this is indicated with (p). The standard error (SE) or standard deviation (SD) as given in the original source is added where available. The mean size is given in standard length (SL) unless otherwise indicated

${ }^{\mathrm{a}} \mathrm{A}$ lipid factor of $39.6 \mathrm{~kJ} \mathrm{~g}^{-1}$ used for energy density estimation

${ }^{\mathrm{b}}$ Measured in total length (TL)

${ }^{\mathrm{c}}$ Sample taken from bird stomach contents, in which the energetic value is potentially overestimated due to water removal in stomach

${ }^{\mathrm{d}} \mathrm{A}$ factor of 4.19 was used to convert calories to joules

had a similar energy density of approximately $23 \mathrm{~kJ} \mathrm{~g}^{-1}$ DW. The energy density of the inner organs was higher $\left(25.7 \mathrm{~kJ} \mathrm{~g}^{-1} \mathrm{DW}\right)$, which is probably caused by ingested food residing in the stomach (Vlieg 1984) or lipids stored in the digestive gland (Phillips et al. 2001).

Two species of squid that are not known to reside in subAntarctic or Antarctic waters (Rodhouse et al. 2014), but which have been found in the stomachs of penguin species, had energy densities of $24.7 \mathrm{~kJ} \mathrm{~g}^{-1} \mathrm{DW}$ (Sepiotheuthis australis) and $23.4 \mathrm{~kJ} \mathrm{~g}^{-1} \mathrm{DW}$ (Nototodarus gouldi; Green and Gales 1990).

Clarke et al. (1985) measured the energy density of several species of squid caught in the north-east Atlantic Ocean. The energy value ranged from $17.5 \mathrm{~kJ} \mathrm{~g}^{-1} \mathrm{DW}\left(1.8 \mathrm{~kJ} \mathrm{~g}^{-1}\right.$ WW; Mastigoteuthis sp.) to $21.5 \mathrm{~kJ} \mathrm{~g}^{-1} \mathrm{DW}\left(2.7 \mathrm{~kJ} \mathrm{~g}^{-1}\right.$ $\mathrm{WW}$; Histioteuthis sp.). The energy value per gram WW was highly variable due to different types of buoyancy regulation used by different squid species, resulting in large differences in water content between species. This did, however, not result in large differences in the energy density per gram DW, the range of which was limited (Clarke et al. 1985).

\section{Gelatinous zooplankton}

A large biomass component of marine ecosystems is formed by gelatinous zooplankton (McInnes et al. 2017). The gelatinous zooplankton includes for instance Ctenophora, or comb jellies, and Cnidaria, including Scyphozoa and Hydrozoa. The latter class contains the order Siphonophora from which species such as Diphyes antarctica can dominate the epipelagic layer particularly during autumn and winter (Flores et al. 2014). Gelatinous species have often been viewed as an unimportant prey item for many organisms, due to both their low energetic value and the difficulty in detecting gelatinous prey with conventional diet assessments methods (e.g. stomach content analysis, leading to potential underestimation of their prevalence as a prey item; McInnes et al. 2017).
However, they have been found to be more than an incidental part of the diet of many larger animals (Fig. 5), including albatrosses and Adélie penguins (Pygoscelis adeliae) in the Southern Ocean (Jarman et al. 2013; Thiebot et al. 2016; McInnes et al. 2017; Thiebot et al. 2017;). Although secondary ingestion cannot be excluded when using DNA analysis, results suggest that they are common prey item (Jarman et al. 2013; McInnes et al. 2017). Video observations captured Adélie penguins feeding on jellyfish, even when other preys were available (Thiebot et al. 2016, 2017). Certain jellyfish species are regularly invested with parasitic amphipods, and although there was no evidence that the penguins were targeting these, they may prove to be a profitable addition (Thiebot et al. 2016).

Two species of Scyphozoa were measured from both the winter Weddell Sea (PS81) and the summer Lazarev Sea (PS89) using bomb calorimetry (Table 10). The energetic density of Periphylla periphylla was $20.4 \mathrm{~kJ} \mathrm{~g}^{-1} \mathrm{DW}$ during winter. Samples consisted of one small individual (93.5 g $\mathrm{WW}$ ) and several larger individuals, with a WW ranging from 470 to $499 \mathrm{~g}$. The average winter energy density of $P$. periphylla was higher compared to $10.8 \mathrm{~kJ} \mathrm{~g}^{-1} \mathrm{DW}$ during summer. The latter measurements were, however, performed on small individuals with an average WW of $7.0 \mathrm{~g}$. This suggests that season has an influence on the energy density of $P$. periphylla, although there could also be an influence of size. No difference was found in the energy density of Atolla spp. between seasons. The average energy density of Atolla spp. was $11.0 \mathrm{~kJ} \mathrm{~g}^{-1} \mathrm{DW}$ during winter and $12.3 \mathrm{~kJ} \mathrm{~g}^{-1} \mathrm{DW}$ during summer. The water content of the Scyphozoa caught during both winter and summer was similar and usually in between 90 and $95 \% \mathrm{WW}$. It should be kept in mind that these individuals were weighed after having been frozen. Due to the potential error in that measurement, energy densities are not given in $\mathrm{kJ} \mathrm{g}^{-1} \mathrm{WW}$. High ash contents may have resulted in an underestimation of the dry weight energy densities of these Scyphozoa. 


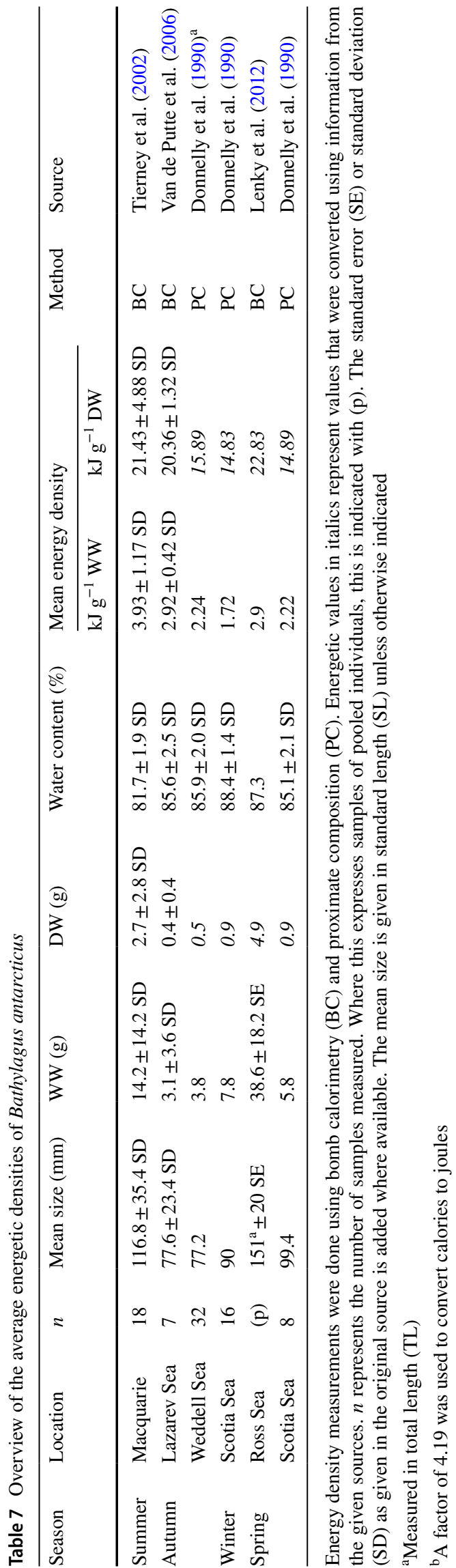

Observations showed that Adélie penguins often attacked the gonads and/or oral arms of jelly fish specifically, and that there was a relationship between the penguin attacks and the visible presence of gonads (Thiebot et al. 2016). Gonads from P. periphylla caught in the summer Lazarev Sea showed a higher energetic density than other body parts (Table 11). Doyle et al. (2007) and Milisenda et al. (2014) also found that gonads had a higher energy content than oral arm or bell tissue, with the exception of one species in which the oral arms yielded a similar energy density as the gonads (Doyle et al. 2007). The energy densities of the bell and collar tissue of $P$. periphylla were very low and likely unrealistic (Table 11; Doyle et al. 2007). These tissues also had very high ash contents (Table 11), although ash content was high in general when compared to other animals.

A measurement using bomb calorimetry on a sample of pooled anterior nectophores of the siphonophore Diphyes antarctica from winter Weddell Sea (PS81) resulted in an energy density of $12.0 \mathrm{~kJ} \mathrm{~g}^{-1} \mathrm{DW}\left(4.0 \mathrm{~kJ} \mathrm{~g}^{-1} \mathrm{WW}\right)$. The ash content of D. antarctica has been reported to be close to $60 \%$ (Donnelly et al. 1994).

Proximate compositions of ctenophore and cnidarian species were measured by Clarke et al. (1992) and Donnelly et al. (1994), which included the species Beroe spp. (Clarke et al. 1992), Pleurobrachia sp. (Clarke et al. 1992), Calycopsis borchgrevinki (Clarke et al. 1992; Donnelly et al. 1994), Botrynema brucei (Clarke et al. 1992), Diphyes antarctica (Clarke et al. 1992; Donnelly et al. 1994) P. periphylla (Donnelly et al. 1994) and Atolla wyvillei (Clarke et al. 1992; Donnelly et al. 1994). The water content of all species was $>95 \% \mathrm{WW}$, while the ash content ranged between 50 and $73 \%$ DW (Clarke et al. 1992; Donnelly et al. 1994). Apart from residual water, there is evidence that suggests that gelatinous species also contain a proportion of amino-carbohydrate which is missed by conventional assay techniques. Furthermore, a proportion of the protein potentially consists of glycoproteins that can be missed or underestimated depending on the technique used (Clarke et al. 1992). This could explain why energy density calculated using proximate composition is far lower than the energy density of carbohydrates, and is an unreliable method for estimating energy density of gelatinous species (Clarke et al. 1992; Donnelly et al. 1994).

Pelagic tunicates, or salps, that occur in the Southern Ocean are widely distributed and can form an important part of the total metazoan biomass, particularly in relatively warm water masses (Pakhomov 2004; Pakhomov et al. 2011). The proximate composition of the pelagic tunicates Salpa fusiformis, Salpa thomsoni and Ihlea racovitzai were measured by Clarke et al. (1992), Donnelly et al. (1994), Dubischar et al. (2006) and Dubischar et al. (2012). Despite similar complications as for other gelatinous zooplankton, some of the sources report an energy density estimate. 


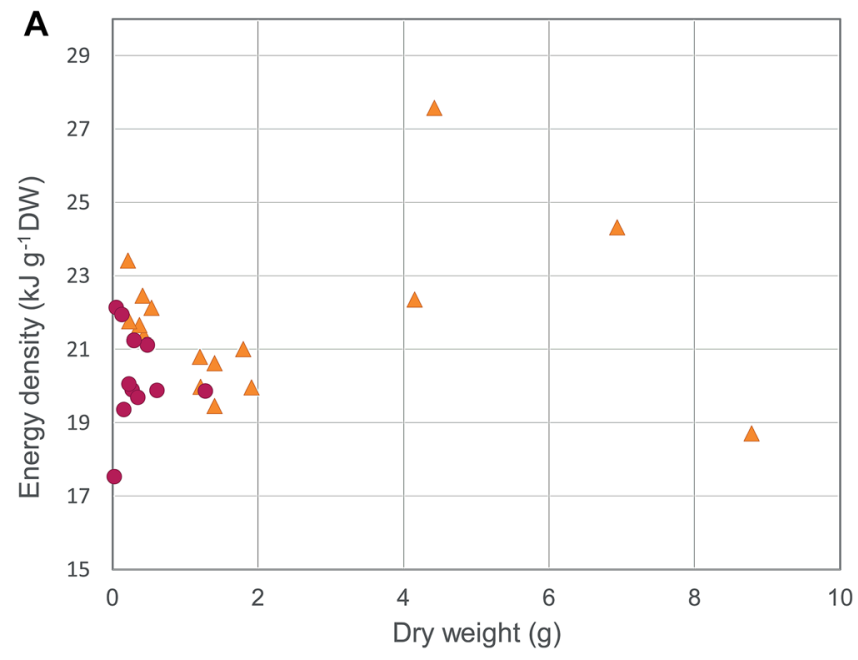

Fig. 4 Bathylagus antarcticus; a the relationship between dry weight (DW) and dry-weight energy density and, b the relationship between DW (\%WW) and energy density $\mathrm{g}^{-1}$ wet weight (WW) including parameters of the linear regression lines $y=a x+b$. Regression parameters are depicted in the figure. Data were obtained from

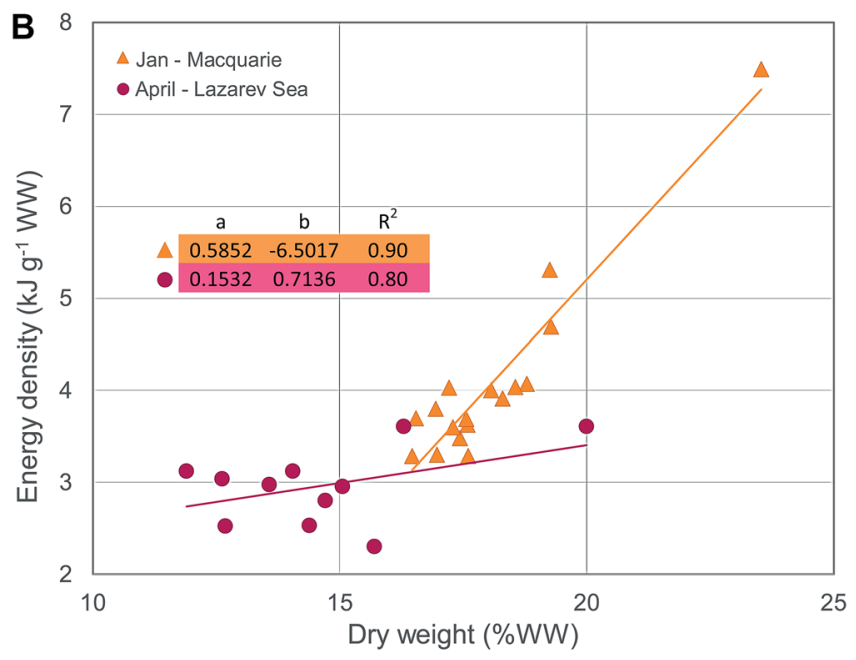

Tierney et al. (2002) (Macquarie Island, January) and Van de Putte et al. (2006) (Lazarev Sea, April). All measurements were done using bomb calorimetry. Legend indicates month and location of data collection

Table 8 Overview of the average energy density of several fish species

\begin{tabular}{|c|c|c|c|c|c|c|c|c|}
\hline \multirow[t]{2}{*}{ Season } & \multirow[t]{2}{*}{ Location } & \multirow[t]{2}{*}{$n$} & \multirow[t]{2}{*}{ Mean size $(\mathrm{mm})$} & \multirow{2}{*}{$\begin{array}{l}\text { Water } \\
\text { content (\% } \\
\text { WW) }\end{array}$} & \multicolumn{2}{|c|}{ Mean energy density } & \multirow[t]{2}{*}{ Method } & \multirow[t]{2}{*}{ Source } \\
\hline & & & & & $\mathrm{kJ} \mathrm{g}^{-1} \mathrm{WW}$ & $\mathrm{kJ} \mathrm{g}^{-1} \mathrm{DW}$ & & \\
\hline \multicolumn{9}{|c|}{ Notolepis coatsi (Paralepididae) } \\
\hline Autumn & Weddell Sea & 5 & 62.4 & $82.2 \pm 2.7$ & 2.65 & 14.89 & $\mathrm{PC}$ & Donnelly et al. (1990) ${ }^{\mathrm{b}}$ \\
\hline Winter & Scotia Sea & 5 & 63.4 & $79.4 \pm 3.4$ & 3.22 & 15.63 & $\mathrm{PC}$ & Donnelly et al. (1990) \\
\hline Summer & East Antarctica & 3 & $168 \pm 52$ & $79.8 \pm 1.3$ & $4.42 \pm 0.33$ & $21.90 \pm 0.73$ & $\mathrm{BC}$ & Van de Putte et al. (2010) \\
\hline \multicolumn{9}{|c|}{ Paradiplospinus gracilis (Gempylidae) } \\
\hline Summer & Possession Island & 1 & 168.7 & 78.9 & $4.6^{\mathrm{a}}$ & $21.8^{\mathrm{a}}$ & $\mathrm{BC}$ & Cherel and Ridoux (1992) \\
\hline Winter & Scotia Sea & 2 & 325.5 & $69.1 \pm 2.4$ & 7.92 & 25.63 & $\mathrm{PC}$ & Donnelly et al. (1990) \\
\hline \multicolumn{9}{|c|}{ Antimora rostrata (Moridae) } \\
\hline Summer & Macquarie & $2(\mathrm{p})$ & $227-225$ & $80.1 \pm 1.0$ & 4.33 & $21.75 \pm 2.28$ & $\mathrm{BC}$ & Tierney et al. (2002) \\
\hline \multicolumn{9}{|c|}{ Stomias gracilis (Stomiidae) } \\
\hline Summer & Macquarie & $18(\mathrm{p})$ & $130-278$ & $77.8 \pm 3.1$ & 5.15 & $23.20 \pm 2.99$ & $\mathrm{BC}$ & Tierney et al. (2002) \\
\hline \multicolumn{9}{|c|}{ Micromesistius australis (Gadidae) } \\
\hline & Patagonia & 3 & $140-150$ & 78.5 & 4.54 & 21.12 & $\mathrm{BC}$ & Ciancio et al. (2007) \\
\hline
\end{tabular}

Families are given in brackets. Energy density measurements were done using bomb calorimetry (BC) and proximate composition (PC). Energy densities in italics represent values that were converted using information from the given sources. $n$ represents the number of samples measured. Where this expresses samples of pooled individuals, this is indicated with (p). The standard deviation (SD) is given where available. The mean size is given in standard length (SL)

${ }^{\text {a }}$ Sample taken from bird stomach contents, in which the energetic value is potentially overestimated due to water removal in stomach

${ }^{\mathrm{b}} \mathrm{A}$ factor of 4.19 was used to convert calories to joules

Dubischar et al. (2012) estimated the WW energy density of S. thompsoni and I. racovitzai to be 0.2 and $0.4 \mathrm{~kJ} \mathrm{~g}^{-1}$ (using the conversion factors $4.1 \mathrm{kcal} \mathrm{g}^{-1}$ for protein and $9.3 \mathrm{kcal} \mathrm{g}^{-1}$ for lipids), which would correspond to 3.1 and $6.7 \mathrm{~kJ} \mathrm{~g}^{-1} \mathrm{DW}$, respectively. They did find that the energy density of I. racovitzai was approximately twice as higher than that of $S$. thompsoni, mainly due to differences in the amount of protein. The amount of protein found by Donnelly et al. (1994) was a lot lower. The proximate composition did not markedly differ between seasons in both studies, suggesting that lipids are not accumulated (Donnelly et al. 1994; Dubischar et al. 2012). Clarke et al. (1992) calculated 
Table 9 Overview of the average energy density of Southern Ocean squid species

\begin{tabular}{|c|c|c|c|c|c|c|c|c|}
\hline \multirow[t]{2}{*}{ Season } & \multirow[t]{2}{*}{ Location } & \multirow[t]{2}{*}{$n$} & \multirow[t]{2}{*}{ Body length (mm) } & \multirow{2}{*}{$\begin{array}{l}\text { Water con- } \\
\text { tent }(\%)\end{array}$} & \multicolumn{2}{|c|}{ Mean energy density } & \multirow[t]{2}{*}{ Method } & \multirow[t]{2}{*}{ Source } \\
\hline & & & & & $\mathrm{kJ} \mathrm{g}^{-1} \mathrm{WW}$ & $\mathrm{kJ} \mathrm{g}^{-1} \mathrm{DW}$ & & \\
\hline \multicolumn{9}{|c|}{ Doryteuthis gahi } \\
\hline & & & & 80.9 & $3.09^{\mathrm{a}}$ & 16.18 & $\mathrm{PC}$ & Pandit and Magar (1972) \\
\hline & Patagonia & 8 & $60-90$ & 76.6 & 4.95 & 21.16 & $\mathrm{BC}$ & Ciancio et al. (2007) \\
\hline \multicolumn{9}{|c|}{ Moroteuthis ingens } \\
\hline \multirow[t]{2}{*}{ Summer } & Possession Island & 1 & & 76.0 & $5.6^{\mathrm{b}}$ & $23.51^{\mathrm{b}}$ & $\mathrm{BC}$ & Cherel and Ridoux (1992) \\
\hline & New Zealand & 6 & 356 & 80.3 & $4.73^{\mathrm{c}}$ & $24.02^{\mathrm{c}}$ & $\mathrm{PC}$ & Vlieg (1984) \\
\hline \multicolumn{9}{|c|}{ Illex argentinus } \\
\hline & Patagonia & 4 & $210-415$ & 76.7 & 5.01 & 21.52 & $\mathrm{BC}$ & Ciancio et al. (2007) \\
\hline
\end{tabular}

In the 'method' column the method used for energetic value determination is indicated, where $\mathrm{BC}$ is bomb calorimetry and PC is proximate composition. Energetic values in italics represent values that were converted using the energetic values, wet weights and dry weights from the given source. $n$ represents the number of samples measured

${ }^{a}$ Based on measurements of water content, lipids $\left(\times 39.7 \mathrm{~kJ} \mathrm{~g}^{-1}\right)$ and crude protein

${ }^{\mathrm{b}}$ Mantle and tentacles

${ }^{\mathrm{c}}$ Based on crude protein

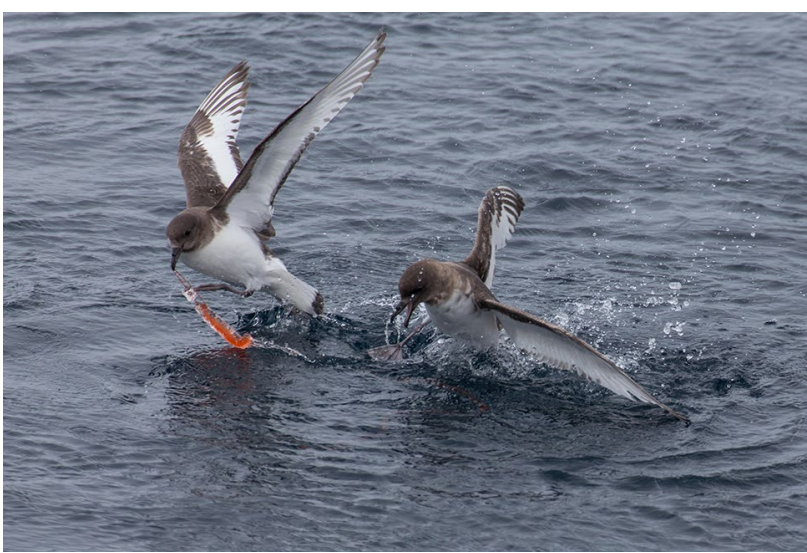

Fig. 5 Antarctic Petrels (Thalassoica antarctica) feeding on gelatinous species in the Lazarev Sea during summer (@) Jan Andries van Franeker) an energy density of $4.6 \mathrm{~kJ} \mathrm{~g}^{-1} \mathrm{DW}$ for $S$. fusiformis. When comparing solitary forms with aggregate forms of S. thompsoni measured from the Bellinghausen Sea in autumn, the amount of protein and lipids was higher in the former, which would result in a higher energy density for the solitaries when converted $\left(5.3 \mathrm{~kJ} \mathrm{~g}^{-1} \mathrm{DW}\right.$ as opposed to $3.2 \mathrm{~kJ} \mathrm{~g}^{-1}$ DW; Dubischar et al. 2006). The reported energy densities for salps are also lower than that of carbohydrates (Clarke et al. 1992). Questions still remain regarding the digestibility of salps. It is suggested that they can be digested entirely but also only partly due to the cellulose-like tunicin present in the tunica (Dubischar et al. 2012 and references therein). Gili et al. (2006) proposed that the salps' stomach may be the main source of energy when preyed upon.

\section{Chaetognaths, polychaetes and gastropods}

Other pelagic zooplankton species for which reported energy densities were found, included chaetognaths, polychaetes and a gastropod (Table S4 of the electronic supplement).

Table 10 Average energy density of scyphozoans \pm standard deviation

\begin{tabular}{|c|c|c|c|c|c|c|c|}
\hline Season & Location & $n$ & Mean DW (mg) & Water content $(\%)$ & $\begin{array}{l}\text { Energy density } \\
\left(\mathrm{kJ} \mathrm{g}^{-1} \mathrm{DW}\right)\end{array}$ & Method & Source \\
\hline \multicolumn{8}{|c|}{ Periphylla periphylla } \\
\hline Winter/spring & Weddell Sea & 8 & $22.0 \pm 9.1$ & $93.6 \pm 1.7$ & $20.42 \pm 1.13$ & $\mathrm{BC}$ & This study (PS81) \\
\hline Summer & Lazarev Sea & 9 & $0.8 \pm 0.9$ & $89.0 \pm 6.1$ & $10.85 \pm 2 . .57$ & $\mathrm{BC}$ & This study (PS89) \\
\hline \multicolumn{8}{|l|}{ Atolla sp. } \\
\hline Winter/spring & Weddell Sea & 5 & $1.57 \pm 0.7$ & $93.0 \pm 2.7$ & $11.16 \pm 3.79$ & $\mathrm{BC}$ & This study (PS81) \\
\hline Summer & Lazarev Sea & 16 & $1.01 \pm 0.3$ & $93.2 \pm 1.6$ & $12.29 \pm 1.41$ & $\mathrm{BC}$ & This study (PS89) \\
\hline
\end{tabular}

Measurements were done using bomb calorimetry. $n$ represents the number of samples measured 
Table 11 The energy density \pm standard deviation of different body parts from the scyphozoan Periphylla periphylla, caught in the summer Lazarev Sea

\begin{tabular}{lcclrrr}
\hline & Mean WW $(\mathrm{g})$ & Mean DW $(\mathrm{g})$ & $\begin{array}{l}\text { Water } \\
\text { content } \\
(\%)\end{array}$ & Ash $(\% \mathrm{DW})$ & \multicolumn{2}{l}{ Energy density } \\
\cline { 5 - 7 } & & & & $\mathrm{kJ} \mathrm{g}^{-1} \mathrm{DW}$ & $\mathrm{kJ} \mathrm{g}^{-1} \mathrm{AFDW}$ \\
\hline Intestine & 385.27 & 18.31 & 95.25 & $66.27 \pm 0.39$ & $6.73 \pm 0.27$ & 19.96 \\
Gonads & 113.12 & 7.66 & 93.23 & $41.57 \pm 2.52$ & $13.28 \pm 0.12$ & 22.73 \\
Bell & 94.46 & 3.66 & 96.12 & $74.90 \pm 0.93$ & $1.15 \pm 0.28$ & 4.59 \\
Tentacles & 123.02 & 5.61 & 95.44 & $55.89 \pm 4.47$ & $8.06 \pm 2.32$ & 18.27 \\
Collar & 259.09 & & & $75.30 \pm 0.51$ & $1.47 \pm 0.33$ & 5.97 \\
\hline
\end{tabular}

Measurements were done using bomb calorimetry. Replicate measurements were performed on the body parts of a single individual
Chaetognaths, such as Eukrohnia hamata, Sagitta gazellae and Sagitta marri, can form a major part of the mesopelagic zooplankton community and are important carnivorous predators (Pakhomov et al. 1999; Flores et al. 2014). These three species are the most abundant in the epipelagic and have a wide, circumpolar distribution (David 1958). Their distribution in the water column has been found to follow increased abundances of their prey, larval krill and copepods (David et al. 2017).

Estimated energy density using proximate composition is available for the three species of chaetognaths and two species of polychaetes in Donnelly et al. (1994). The dry-weight energy density of chaetognaths ranged between $5.0 \mathrm{~kJ} \mathrm{~g}^{-1}$ DW of $S$. gazellae caught in autumn and $11.7 \mathrm{~kJ} \mathrm{~g}^{-1} \mathrm{DW}$ of $E$. hamata caught during winter. The energy densities of $E$. hamata and $S$. gazellae were higher in winter than in autumn. Seasonal changes in energy content are suggested to be a result of trophodynamics (Donnelly et al. 1994). Sagitta marri had a winter energy density of $11.3 \mathrm{~kJ} \mathrm{~g}^{-1}$ DW. All chaetognath species had high water and ash contents.

The polychaetes Vanadis antarctica and Tomopteris carpenteri are both oceanic species that can be found in the entire water column (Boysen-Ennen and Piatkowski 1988; Fernández-Álamo and Thuesen 1999). They had estimated energy densities of $14.2 \mathrm{~kJ} \mathrm{~g}^{-1} \mathrm{DW}$ during autumn and $9.2 \mathrm{~kJ} \mathrm{~g}^{-1} \mathrm{DW}$ during winter, respectively (Donnelly et al. 1994). The energy density of T. carpenteri was also estimated from individuals caught near South Georgia. The reported value of $12.4 \mathrm{~kJ} \mathrm{~g}^{-1}$ DW was calculated using the values $39.5 \mathrm{~kJ} \mathrm{~g}^{-1}$ for lipids and $23.9 \mathrm{~kJ} \mathrm{~g}^{-1}$ for protein (Clarke et al. 1992).

A proximate composition estimate of the pelagic gastropod Clione limacina antarctica from the McMurdo Sound yielded an energy density of $24.8 \mathrm{~kJ} \mathrm{~g}^{-1}$ DW (Bryan et al. 1995). This gastropod can be very abundant in certain seasons or areas, and contains defensive chemicals to defend itself against predation (Bryan et al. 1995).

\section{Benthic invertebrate species}

McClintock (1987, 1989) and McClintock et al. (2004, 2006) reported energy densities of benthic echinoderms, sponges and a tunicate. All estimates of the energy density of these species were done using proximate composition. The sea stars Granaster nutrix and Neosmilaster georgianus were investigated in McClintock et al. (2006). Measurements were done on the pyloric caeca and body wall separately which yielded 24.8 and $8.5 \mathrm{~kJ} \mathrm{~g}^{-1}$ DW for G. nutrix, and 26.5 and $14.1 \mathrm{~kJ} \mathrm{~g}^{-1} \mathrm{DW}$ for $N$. georgianus, respectively. The energy densities of the body walls of 13 echinoderm species from McMurdo Sound ranged from 10.5 (Odontaster meridionalis) to 18.2 (Porania antarctica) $\mathrm{kJ} \mathrm{g}^{-1} \mathrm{DW}$ (McClintock 1989). The proximate composition of different body parts of the aforementioned study can be found in McClintock and Pearse (1987). The energy densities of 17 species of benthic sponges from McMurdo Sound ranged from $5.1 \mathrm{~kJ} \mathrm{~g}^{-1}$ DW (Sphaerotylus antarcticus) to $17.4 \mathrm{~kJ} \mathrm{~g}^{-1} \mathrm{DW}$ (Dendrilla membranosa; McClintock 1987). The energy density of the benthic tunicate Distaplia cylindrica was estimated at $14.7 \mathrm{~kJ} \mathrm{~g}^{-1}$ DW (McClintock et al. 2004). This benthic tunicate had a lower water content and higher protein content compared to the pelagic tunicates (Donnelly et al. 1994; McClintock et al. 2004; Dubischar et al. 2012).

An energy density of $21.8 \mathrm{~kJ} \mathrm{~g}^{-1}$ DW was estimated using proximate composition for the nemertean Parborlasia corrugatus, collected in the McMurdo Sound during spring (Heine et al. 1991). Three bivalve species from the Patagonian shelf, Aulacomya atra, Perumytilus purpuratus and Mytilus edulis, yielded energy densities of 19.2, 20.0 and $17.9 \mathrm{~kJ} \mathrm{~g}^{-1} \mathrm{DW}$, respectively. Animals were measured without shells using bomb calorimetry (Ciancio et al. 2007).

\section{Discussion}

\section{Data gaps}

There is a focus on certain species, but the Southern Ocean is composed of different biogeographical regions that can 
have a distinct biodiversity and community structure, and specific key species. For instance, for euphausiids many studies focus on Euphausia superba, but other species can be of high importance in certain areas. In the continental shelf region, Euphausia crystallorophias is an important food source, for instance for Adélie penguins in the Ross Sea and at Adélie Land (Ainley et al. 1998; Cherel 2008), and for minke (Balaenoptera acutorostrata) and blue whales (Balaenoptera musculus; Laws 1977; Ishii et al. 1998). The euphausiid Euphausia vallentini can be a major food source for many sea birds in particular biogeographic regions, for instance at Heard Island and the Crozet Islands (Ridoux 1994; Deagle et al. 2007). Several amphipod species are found in the diet of many bird species (Hindell 1989; Ridoux 1994; Van Franeker et al. 2001), although their contribution to the diet varies significantly between regions. The hyperiid amphipod Themisto gaudichaudii, for example, has a wide distribution and is found in variable amounts in the diet of many species, but seems to be an important prey item in the region of the Kerguelen Islands particularly (Bocher et al. 2001). Similarly, the copepod Paraeuchaeta antarctica has been found to be abundant in the diet of bird species in the Kerguelen region (Bocher et al. 2002).

A better seasonal or regional coverage of the energy density of species is desirable as it can give insight into a species life cycle and behaviour, because several top predator species show a change in diet between seasons (Ridoux 1994). For example, the fish feeding Cape petrel (Daption capense) switches to a squid dominated diet in the Weddell/ Scotia Sea in autumn (Ainley et al. 1991), while the Arctic tern (Sterna paradisaea) feeds mainly on Electrona antarctica in spring, but on Antarctic krill in autumn (Ainley et al. 1991). Adélie penguins in the Ross Sea, feeding mainly on krill at the start of the season, increased their proportion of fish in the diet together with their foraging trip duration. This is likely a result of a change in food availability due to increased predation pressure by the penguins themselves (Ainley et al. 2015).

There are many species groups that are overlooked as they are not known to be an important part of the diet of top predators, but which can reach high numbers and biomasses in certain habitats or seasons and are, therefore, important parts of the Southern Ocean food web. These include previously mentioned groups such as salps (Pakhomov et al. 2002), chaetognaths, siphonophores, ctenophores, gastropods (Hunt et al. 2008; Flores et al. 2011, 2014), other small krill species such as Euphausia frigida, but also benthic species such as bivalves and limpets (Favero et al. 1997; Ainley et al. 2003). Furthermore, a better coverage of the energy density of Southern Ocean species can help to predict what happens if prey distribution changes. For example, research has shown that areas dominated by Antarctic krill may be replaced with a dominance of salps due to warming waters (Pakhomov et al. 2002; Atkinson et al. 2004; Ross et al. 2014), which may have significant food web implications. An effect of food availability on annual fledging mass of Macaroni penguin chicks (Eudyptes chrysolophus) was shown at Bird Island, South Georgia (Waluda et al. 2012). The fledging mass of penguin chicks could be related to the energy density of the prey in combination with prey size and mobility, and was highest in years where $E$. superba dominated the diet, and lowest when there were large proportions of fish and other crustaceans, such as T. gaudichaudii and E. frigida (Waluda et al. 2012). In contrast, male Adélie penguin chicks had a higher proportion of fish in the diet and were growing faster than female chicks, which ate higher proportions of krill (Jennings et al. 2016). Model simulations also suggested that penguin chicks that supplemented their diet with fish (Pleuragramma antarctica), instead of feeding solely on Antarctic krill, would be heavier and more likely to recruit (Chapman et al. 2011). The quantity of milk fat of fur seals (Arctocephalus gazella) at Kerguelen was found to be influenced by the proportion of myctophids in the diet (Lea et al. 2006).

The energy density of a prey species might change as consequence of warming temperatures. Oxygen consumption and metabolic rate have been found to increase with increasing temperature across species (Brockington and Clarke 2001). This could not only lead to smaller sized individuals (Atkinson 1994; Daufresne et al. 2009; Baudron et al. 2014), but also to changes in community structure due to a need for increased consumption leading to, for example, changes in predator-prey interactions or intraspecific competition (Bruno et al. 2015). The reduction in body size with increasing temperature has been found for many myctophid fish species, which could potentially lead to these fish shifting to a different size of prey or becoming a less valuable food source for predators (Saunders and Tarling 2018). In addition, the energy allocation (for instance, towards growth or build-up of reserves) has been found to change under different temperature conditions in a study on zoarcid fish species (Brodte et al. 2006).

Although for all types of studies using a species-specific energy density value it would be preferable to use an estimate that is specific for, e.g. region, season and body size, a generalized estimate of the energy density of a species could be useful in cases where this is not available. For many species, however, only a single record of their energy density exists. Many records also often consist of one individual or a single-pooled sample. Therefore, more measurements are necessary to validate and generalize energy densities of species, and sources of variation within species. For $E$. antarctica there are relatively many individual records (284), which yield a mean energy density of $30.26 \mathrm{~kJ} \mathrm{~g}^{-1}$ DW and $8.94 \mathrm{~kJ} \mathrm{~g}^{-1} \mathrm{WW}$. Results have shown, however, that sources of variation include size and region. Another way to estimate 
a mean value could be using a median value of all recorded mean energy densities, which would result in median values of $29.61 \mathrm{~kJ} \mathrm{~g}^{-1} \mathrm{DW}$ and $9.08 \mathrm{~kJ} \mathrm{~g}^{-1} \mathrm{WW}$ for E. antarctica and $21.9 \mathrm{~kJ} \mathrm{~g}^{-1} \mathrm{DW}$ and $5.01 \mathrm{~kJ} \mathrm{~g}^{-1} \mathrm{WW}$ for E. superba. For the latter species it is, however, clear that the energy densities differ between sexes and developmental stages, while regional differences are uncertain. For aforementioned estimates only bomb calorimeter measurements were used.

Measuring energy density using bomb calorimetry and proximate composition are time consuming. Therefore, increased information on relationships between energy density and other, more easy to measure, parameters could be helpful. These may include insights in the effect of size/ age/maturity on energy density within species and variation between seasons and regions. Also, relationships between water content or proportion of body carbon and energy density, including more information on differences and similarities between, for example, species, families and classes, would be useful to evaluate the accuracy of values used. In addition, it would increase the precision of studies and models based on energy density, when using values that take interspecific variation into account. Currently, regressions are generally limited to certain fish species and on an individual basis for Antarctic krill (Färber-Lorda et al. 2009a). To obtain such correlations, measurements on individuals are most useful. A standard bomb calorimeter needs, however, quite a large dry weight sample and thus for measuring small animals it is necessary to have access to a micro-bomb calorimeter.

\section{Size/age-energy density relationships}

Relationships between size and dry-weight energy density are found for fish, but differ between species. A positive relationship between size and dry weight energy density was found for the myctophids Gymnoscopelus piabilis, Electrona carlsbergi (Lea et al. 2002) and E. antarctica. For other fish species such as Bathylagus antarcticus (Tierney et al. 2002; Van de Putte et al. 2006), Pleuragramma antarctica (Van de Putte et al. 2010) and other fish from the study of Lea et al. (2002), no relationship was found, and fish had the same dry-weight energy density regardless of size. In addition, Tierney et al. (2002) found negative relationships between size and dry weight energy density. Most relationships are, however, not linear, but show differences between size classes. Therefore, as recommended by Van de Putte et al. (2006), it is useful to separate energy densities in age or size classes, using distinct energy densities for each age group. In particular, in trophodynamic studies and research on prey utilization of species, as predators are known to often feed on a particular prey size (Van Franeker et al. 2001). However, again more data are needed to see if size/energy density relationships show a general trend rather than an incidental occurrence, and if differences are found, to be able to characterize the size classes between which differences occur. The available data on Gymnoscopelus braueri show an example where there is a (negative) relationship in one dataset, but none in the other (Tierney et al. 2002; Van de Putte et al. 2006). Furthermore, it is currently unclear how energy density in young fish is allocated because not all small specimens show increased energy density with decreasing water content, as would be expected (Tierney et al. 2002).

In krill, and most likely other crustaceans, there are marked differences in energy density between developmental stages. Predators have been found to have a higher proportion of female krill in their diet, probably also due to their larger size (Reid et al. 1996). It would be useful to gain information on the energy densities of krill based on size, as predators also prey upon particular sizes, and sizes of different developmental stages usually overlap. For instance, fulmarine petrels consume krill of approximately $35 \mathrm{~mm}$ (Van Franeker et al. 2001), which is a size including both juvenile and sub-adult krill (Siegel 1987, 2012). For species other than E. superba and fish, size or developmental stage specific data are lacking completely, although data suggest that there may be differences in energy density between size classes, for example in the jelly fish Periphylla periphylla.

\section{Water content-energy density relationships}

The relationship between water content and energy content (in $\mathrm{kJ} \mathrm{g}^{-1} \mathrm{WW}$ ) can help estimating the energy density based on water content (usually expressed in DW as a percentage of WW), in which case only the determination of wet weight and dry weight or water content is needed (Hartman and Brandt 1995). The relationship between water content and energy density (WW) of E. antarctica was similar between seasons and regions, and thus a single-regression model, using all available individual measurements, should give good, generally useful parameters for the estimation of energy density on a WW basis given the water content:

$\mathrm{ED}_{\mathrm{WW}}=0.393 \times P_{\mathrm{DW}}-2.977\left(R^{2}=0.93, n=252\right)$, where $\mathrm{ED}_{\mathrm{WW}}$ represents the energy density in $\mathrm{kJ} \mathrm{g}^{-1} \mathrm{WW}$ and $P_{\mathrm{DW}}$ the dry weight as a percentage of WW.

Using the available individual data of G. braueri, a generalized regression model would yield similar parameters:

$\mathrm{ED}_{\mathrm{WW}}=0.344 \times P_{\mathrm{DW}}-1.539\left(R^{2}=092, n=33\right)$.

This model does, however, exclude the smaller fish ( $<40 \mathrm{~mm}$ ) from Tierney et al. (2002) which had a significantly higher energy density than the larger fish, for which the cause remains unclear. The slopes of the models for $E$. antarctica and $G$. braueri differed significantly from each other (ANCOVA, $p=0.006$ ). 
Differences in regression slopes between fish species (Van de Putte et al. 2006, 2010) reveal that the relationship between water content and energy density (WW) differ between families at least. Hartman and Brandt (1995) suggested that similar models can be used for fish within the same order or family, but recommended using speciesspecific models when available, especially in species which show marked seasonal changes in energy density. In this review, individual data on Bathylagus antarcticus showed that the relationship can also differ between seasons and or regions. Furthermore, the different feeding habitats and wide range of energy densities of nototheniid fishes suggest that there might be large differences in water content/energy density relationships between species of the same family. Similar modelling was done by Ciancio et al. (2007), including crustaceans, fish and cephalopods. They also found that same genus models would produce similar results as species-specific models, although this was not the case for some groups which were less well represented by aggregated models and for which species-specific models were recommended. Therefore, more individual data are needed to establish regression models for different species, to compare the relationship between water content and energy density within families and to evaluate if the established regression models can be used in a general manner, also for taxa other than fish.

\section{Conclusion}

A large amount of data are available on the energy density of potential prey species in the Southern Ocean. The available data are, however, strongly skewed towards a few large, abundant and relatively easily accessible taxa. Furthermore, information on the seasonal and regional variability of energy densities is still limited in most species. This information, however, would be key to the improvement of bioenergetic models and food web models. Bomb calorimetry is hitherto regarded as the most accurate method for energy density measurements. However, proximate composition analysis at various levels can provide a range of additional parameters often used in ecological studies. Important taxa for the energy flux of Antarctic food webs remain undersampled. In a changing Southern Ocean, smaller zooplankton and gelatinous species may become more abundant. Such a shift would likely change food web energetics significantly at various levels, affecting the carrying capacity of the ecosystem for top predators and harvesting of living resources. It will, therefore, become increasingly important to include small and gelatinous zooplankton in energy flux models and ecosystem studies, warranting the need for more energetic measurements of these organisms.
Acknowledgements We are grateful to the captains and crew of RV Polarstern during expeditions PS81 and PS89, and to Michiel van Dorssen, Martina Vortkamp, André Meijboom, Giulia Castellani, Julia Ehrlich, Bram Fey and Carmen David for their contribution to sample collection during these expeditions. We thank Evgeny Pakhomov and Brian Hunt for providing fish and jelly fish samples during PS81. Thanks to Sander Holthuijsen, Felipe Oliveira Ribas and Henk van der Veer (Netherland Institute for Sea Research) for the use of their bomb calorimeter and their help with the analysis. Thanks to Megan Tierney and Jaime Färber-Lorda for providing individual data. We thank the Editor Dr A. Atkinson and the reviewers for their comments on a previous version of the manuscript.

Funding Antarctic research by Wageningen Marine Research is commissioned by the Netherlands Ministry of Agriculture, Nature and Food Quality (LNV) under its Statutory Research Task Nature \& Environment WOT-04-009-047.04. The Netherlands Polar Programme (NPP), managed by the Netherlands Organisation for Scientific Research (NWO) funded this research under project nr. ALW 866.13.009. This study was furthermore conducted under the Helmholtz Association Research Programme Polar regions And Coasts in the changing Earth System II (PACES II), Topic 1, WP 5 as part of the Helmholtz Association Young Investigators Group Iceflux: Ice-ecosystem carbon flux in polar oceans (VH-NG-800). Logistics for Antarctic field work on Polarstern were provided under expedition Grants no: AWI-PS81_01 (WISKY) and AWI-PS89_02. This is a contribution of the SCAR Antarctic Biodiversity Platform (http://www.biodiversity.aq), funded by the Belgian Science Policy Office (BELSPO, contract n ${ }^{\circ}$ FR/36/AN1/ AntABIS).

\section{Compliance with ethical standards}

Conflict of interest The authors declare that they have no conflict of interests.

Ethical approval All applicable international, national, and/or institutional guidelines for the care and use of animals were followed and all necessary approvals have been obtained.

Open Access This article is distributed under the terms of the Creative Commons Attribution 4.0 International License (http://creativeco mmons.org/licenses/by/4.0/), which permits unrestricted use, distribution, and reproduction in any medium, provided you give appropriate credit to the original author(s) and the source, provide a link to the Creative Commons license, and indicate if changes were made.

\section{References}

Ainley DG, Jacobs SS (1981) Sea-bird affinities for ocean and ice boundaries in the Antarctic. Deep Sea Res 28A(10):1173-1185. https://doi.org/10.1016/0198-0149(81)90054-6

Ainley DG, Fraser WR, Smith WO, Hopkins TL, Torres JJ (1991) The structure of upper level pelagic food webs in the Antarctic: effect of phytoplankton distribution. J Mar Syst 2:111-122. https://doi. org/10.1016/0924-7963(91)90017-O

Ainley DG, Wilson PR, Barton KJ, Ballard G, Nur N, Karl B (1998) Diet and foraging effort of Adélie penguins in relation to packice conditions in the southern Ross Sea. Polar Biol 20:311-319. https://doi.org/10.1007/s003000050308

Ainley DG, Ballard G, Barton KT, Karl BJ, Rau GH, Ribic CA, Wilson PR (2003) Spatial and temporal variation of diet within 
a presumed metapopulation of Adélie penguins. Condor 105(1):95-106. https://doi.org/10.1650/0010-5422

Ainley DG, Ballard G, Dugger KM (2006) Competition among penguins and cetaceans reveals trophic cascades in the western Ross Sea, Antarctica. Ecology 87(8):2080-2093. https://doi. org/10.1890/0012-9658(2006)87[2080:capacr]2.0.co;2

Ainley DG, Ballard G, Jones RM, Jongsomjit D, Pierce SD, Smith WO Jr, Veloz S (2015) Trophic cascades in the western Ross Sea, Antarctica: revisited. Mar Ecol Prog Ser 534:1-16. https://doi. org/10.3354/meps 11394

Anthony JA, Roby DD, Turco KR (2000) Lipid content and energy density of forage fishes from the northern Gulf of Alaska. J Exp Mar Biol Ecol 248(1):52-78. https://doi.org/10.1016/S0022 -0981(00)00159-3

Arndt CE, Swadling KM (2006) Crustacea in Arctic and Antarctic sea ice: distribution, diet and life history strategies. In: Southward AJ, Sims DW (eds.) Advances in marine biology, vol 51. pp 197-315, Elsevier, Amsterdam

Arrigo KR, Worthen D, Schnell A, Lizotte MP (1998) Primary production in Southern Ocean waters. J Geophys Res Oceans 103 (C8):15587-15600

Arrigo KR, Van Dijken GL, Bushinsky S (2008) Primary production in the Southern Ocean, 1997-2006. J Geophys Res Oceans 113:C08004. https://doi.org/10.1029/2007JC004551

Atkinson D (1994) Temperature and organism size: a biological law for ectotherms? Adv Ecol Res 25:1-58

Atkinson A (1998) Life cycle strategies of epipelagic copepods in the Southern Ocean. J Mar Syst 15(1-4):289-311

Atkinson A, Siegel V, Pakhomov E, Rothery P (2004) Long-term decline in krill stock and increase in salps within the Southern Ocean. Nature 432:100-103. https://doi.org/10.1038/natur e02996

Atkinson A, Siegel V, Pakhomov EA, Rothery P, Loeb V, Ross RM, Quetin LB, Schmidt K, Fterwell P, Murphy EJ, Tarling GA, Fleming AH (2008) Oceanic circumpolar habitats of Antarctic krill. Mar Ecol Prog Ser 362:1-23. https://doi.org/10.3354/ meps07498

Atkinson A, Ward P, Hunt BPV, Pakhomov EA, Hosie G (2012) An overview of southern ocean zooplankton data: abundance, biomass, feeding and functional relationships. CCAMLR Sci 19:171-218

Båmstedt U (1981) Water and organic content of boreal macrozooplankton and their significance for the energy content. Sarsia 66(1):59-66

Båmstedt U (1986) Chemical composition and energy content. In: Corner EDS, O'Hara SCM (eds) The biological chemistry of marine copepods. Clarendon Press, Oxford, pp 1-58

Barrera-Oro E (2002) The role of fish in the Antarctic food web: differences between inshore and offshore waters in the Southern Scotia Arc and west Antarctic Peninsula. Antarct Sci 14(4):293-309. https://doi.org/10.1017/S0954102002000111

Bathmann UV, Makarov RR, Spiridonov VA, Rohardt G (1993) Winter distribution and overwintering strategies of the Antarctic copepod species Calanoides acutus, Rhincalanus gigas and Calanus propinquus (Crustacea, Calanoida) in the Weddell Sea. Polar Biol 13:333-346. https://doi.org/10.1007/BF00238360

Baudron AR, Needle CL, Rijnsdorp AD, Marshall CT (2014) Warming temperatures and smaller body sizes: synchronous changes in growth of North Sea fishes. Glob Change Biol 20(4):1023-1031. https://doi.org/10.1111/gcb.12514

Belkin I (2007) Southern Ocean: fronts and frontal zones. In: Riffenburgh B (ed) Encyclopedia of the Antarctic. Taylor \& Francis Group, New York

Belkin IM, Gordon AL (1996) Southern Ocean front from the Greenwich meridian to Tasmania. J Geophys Res 101:3675-3696. https ://doi.org/10.1029/95JC02750
Benedito-Cecilio E, Morimoto M (2002) Effect of preservatives on caloric density in the muscles of Hoplias aff. malabaricus (Bloch, 1794) (Osteichthyes, Erythrinidae). Maringá 24(2):489_ 492. https://doi.org/10.4025/actascibiolsci.v24i0.2381

Bocher P, Cherel Y, Labat JP, Mayzaud P, Razouls S, Jouventin P (2001) Amphipod-based food web: Themisto gaudichaudii caught in nets and by seabirds in Kerguelen waters, southern Indian Ocean. Mar Ecol Prog Ser 223:261-276. https://doi. org/10.3354/meps223261

Bocher P, Cherel Y, Alonzo F, Razouls S, Labat JP, Mayzaud P, Jouventin P (2002) Importance of the large copepod Paraeuchaeta antarctica (Giesbrecht, 1902) in coastal waters and the diet of seabirds at Kerguelen, Southern Ocean. J Plankton Res 24(12):1317-1333. https://doi.org/10.1093/plankt/24.12.1317

Boysen-Ennen E, Piatkowski U (1988) Meso- and macrozooplankton communities in the Weddell Sea, Antarctica. Polar Biol 9:17-35. https://doi.org/10.1007/BF00441761

Brett JR, Groves TDD (1979) Physiological energetics. In: Hoar WS, Randall DJ (eds) Fish physiology, vol 8. Academic Press, New York, pp 279-352

Brockington S, Clarke A (2001) The relative influence of temperature and food on the metabolism of a marine invertebrate. J Exp Mar Biol Ecol 258:87-99. https://doi.org/10.1016/S0022 -0981(00)00347-6

Brodte E, Knust R, Pörtner HO (2006) Temperature-dependent energy allocation to growth in Antarctic and boreal eelpout (Zoarcidae). Polar Biol 30:95-107. https://doi.org/10.1007/s0030 0-006-0165-y

Brody S (1945) Bioenergetics and growth. Reinhold Pub. Corp, New York

Bruno JF, Carr LA, O'Connor MI (2015) Exploring the role of temperature in the ocean through metabolic scaling. Ecology 96(12):3126-3140. https://doi.org/10.1890/14-1954.1

Bryan PJ, Yoshida WY, McClintock JB, Baker BJ (1995) Ecological role for pteroenone, a novel antifeedant from the conspicuous antarctic pteropod Clione antarctica (Gymnosomata: Gastropoda). Mar Biol 122:271-277. https://doi.org/10.1007/BF003 48940

Chapman EW, Hofmann EE, Patterson DL, Ribic CA, Fraser WR (2011) Marine and terrestrial factors affecting Adélie penguin Pygoscelis adeliae chick growth and recruitment off the western Antarctic Peninsula. Mar Ecol Prog Ser 436:273-289. https:// doi.org/10.3354/meps09242

Cherel Y (2008) Isotopic niches of emperor and Adélie penguins in Adélie Land, Antarctica. Mar Biol 154(5):813-821. https://doi. org/10.1007/s00227-008-0974-3

Cherel Y, Kooyman GL (1998) Food of emperor penguins (Aptenodytes forsteri) in the western Ross Sea, Antarctica. Mar Biol 130:335-344. https://doi.org/10.1007/s002270050253

Cherel Y, Ridoux V (1992) Prey species and nutritive value of food fed during summer to king penguin Aptenodytes patagonica chicks at Possession Island, Crozet Archipelago. Ibis 134:118-127. https ://doi.org/10.1111/j.1474-919X.1992.tb08388.x

Cherel Y, Ridoux V, Rodhouse PG (1996) Fish and squid in the diet of king penguin chicks, Aptenodytes patagonicus, during winter at sub-antarctic Crozet Islands. Mar Biol 126:559-570. https://doi. org/10.1007/bf00351323

Ciancio JE, Pascual MA, Beauchamp DA (2007) Energy density of Patagonian aquatic organisms and empirical predictions based on water content. Trans Am Fish Soc 136:1415-1422. https:// doi.org/10.1577/t06-173.1

Clarke A (1980) The biochemical composition of krill, Euphausia superba Dana, from South Georgia. J Exp Mar Biol Ecol 43:221236. https://doi.org/10.1016/0022-0981(80)90049-0 
Clarke A (1984) Lipid content and composition of Antarctic krill, Euphausia superba Dana. J Crustac Biol 4:285-294. https://doi. org/10.1163/1937240X84X00660

Clarke A, Prince PA (1980) Chemical composition and calorific value of food fed to mollymauk chicks Diomedea melanophris and $D$. chrysostoma at Bird Island, South Georgia. Ibis 122:488-494. https://doi.org/10.1111/j.1474-919x.1980.tb00903.x

Clarke A, Clarke MR, Holmes LJ, Waters TD (1985) Calorific values and elemental analysis of eleven species of oceanic squids (Mollusca: Cephalopoda). J Mar Biol Assoc UK 65:983-986. https:// doi.org/10.1017/S0025315400019457

Clarke A, Holmes LJ, Gore DJ (1992) Proximate and elemental composition of gelatinous zooplankton from the Southern Ocean. J Exp Mar Biol Ecol 155:55-68. https://doi.org/10.1016/00220981(92)90027-8

Craig JF (1977) The body composition of adult perch, Perca fluviatilis in Windermere, with Reference to seasonal changes and reproduction. J Anim Ecol 46(2):617-632. https://doi. org/10.2307/3834

Craig JF, Kenley MJ, Talling JF (1978) Comparative estimations of the energy content of fish tissue from bomb calorimetry, wet oxidation and proximate analysis. Freshw Biol 8:585-590. https ://doi.org/10.1111/j.1365-2427.1978.tb01480.x

Croxall JP, Prince PA (1982) Calorific content of squid (Mollusca: Cephalopoda). Bull Br Antarct Surv 55:27-31

Cuzin-Roudy J, Virtue P, Mayzaud P, Albessard A (1999) The scheduling of spawning with the molt cycle in krill (Crustacea: Euphausiacea): a strategy for allocating lipids to reproduction. Invertebr Reprod Dev 36:163-170. https://doi. org/10.1080/07924259.1999.9652694

Cuzin-Roudy J, Irisson JO, Penot F, Kawaguchi S, Vallet C (2014) Chapter 6.9. Southern Ocean euphausiids. In: De Broyer C, Koubbi P, Griffiths HJ, Raymond B, Udekem d'Acoz Cd' et al (eds) Biogeographic Atlas of the Southern Ocean. Scientific Committee on Antarctic Research, Cambridge, pp 309-320

Danulat E (1987) Digestibility of chitin in cod, Gadus morhua, in vivo. Helgoländer Meeresuntersuchungen 41:425-436. https ://doi.org/10.1007/BF02365402

Dauby P, Scailteur Y, De Broyer C (2001) Trophic diversity within eastern Weddell Sea amphipod community. Hydrobiologica 443:69-86. https://doi.org/10.1023/A:1017596120422

Dauby P, Nyssen F, De Broyer C (2003) Amphipods as a food source for higher trophic levels in the Southern Ocean: a synthesis. In: Huskes AHL, Gieskes WWC, Rozema J, Schorno RML, Van der Vies SM, Wolff WJ (eds) Antarctic biology in a global context. Backhuys Publishers, Leiden, pp 129-134

Daufresne M, Lengfellner K, Sommer U (2009) Global warming benefits the small in aquatic ecosystems. PNAS 106(31):1278812793. https://doi.org/10.1073/pnas.0902080106

David PM (1958) The distribution of the Chaetognatha of the Southern Ocean. Discov Rep 29:199-228. https://doi. org/10.1007/978-94-015-7204-0_8

David C, Schaafsma FL, Van Franeker JA, Lange B, Brandt A, Flores $\mathrm{H}$ (2017) Community structure of under-ice fauna in relation to winter sea-ice habitat properties from the Weddell Sea. Polar Biol 40(2):247-261. https://doi.org/10.1007/s00300-016-1948-4

De Broyer C, Koubbi P (2014) Chapter 1.1. The biogeography of the Southern Ocean. In: De Broyer C, Koubbi P, Griffiths HJ, Raymond B, Udekem d'Acoz Cd' et al (eds) Biogeographic Atlas of the Southern Ocean. Scientific Committee on Antarctic Research, Cambridge, pp 328-362

De Broyer C, Scailteur Y, Chapelle G, Rauschert M (2001) Diversity of epibenthic habitats of gammaridean amphipods in the eastern Weddell Sea. Polar Biol 24:744-753. https://doi.org/10.1007/ s003000100276
Deagle BE, Gales NJ, Evans K, Jarman SN, Robinson S, Treblico R, Hindell MA (2007) Studying sea bird diet through genetic analysis of faecea: a case study on macaroni penguins (Eudyptes chrysolophus). PLoS One 2(9):e831. https://doi.org/10.1371/ journal.pone.0000831

Dinniman MS, Klinck JM, Smith WO Jr (2011) A model study of circumpolar deep water on the West Antarctic Peninsula and Ross Sea continental shelves. Deep Sea Res II 58:1508-1523. https:// doi.org/10.1016/j.dsr2.2010.11.013

Donnelly J, Torres JJ (2008) Pelagic fishes in the Marguerite Bay region of the West Antarctic Peninsula shelf. Deep Sea Res II 55(3-4):523-539. https://doi.org/10.1016/j.dsr2.2007.11.015

Donnelly J, Torres JJ, Hopkins TL, Lancraft TM (1990) Proximate composition of Antarctic mesopelagic fishes. Mar Biol 106:1323. https://doi.org/10.1007/BF02114670

Donnelly J, Torres JJ, Hopkins TL, Lancraft TM (1994) Chemical composition of Antarctic zooplankton during austral fall and winter. Polar Biol 14:171-183. https://doi.org/10.1007/BF00240522

Doyle TK, Houghton JDR, McDevitt R, Davenport J, Hays GC (2007) The energy density of jellyfish: estimates from bomb-calorimetry and proximate-composition. J Exp Mar Biol Ecol 343(249):252. https://doi.org/10.1016/j.jembe.2006.12.010

Dubischar CD, Pakhomov EA, Bathmann UV (2006) The tunicate Salpa thompsoni ecology in the Southern Ocean II. Proximate and elemental composition. Mar Biol 149:625-632. https://doi. org/10.1007/s00227-005-0226-8

Dubischar CD, Pakhomov EA, Von Harbou L, Hunt BPV, Bathmann UV (2012) Salps in the Lazarev Sea, Southern Ocean: II. Biochemical composition and potential prey value. Mar Biol 159:15-24. https://doi.org/10.1007/s00227-011-1785-5

Duhamel G et al (2014) Chapter 7. Biogeographic patterns of fish. In: De Broyer C, Koubbi P, Griffiths HJ, Raymond B, Udekem d'Acoz Cd' et al (eds) Biogeographic Atlas of the Southern Ocean. Scientific Committee on Antarctic Research, Cambridge, pp 328-362

Durand H, Nicolle JP (1980) Preliminary experiments on the transformation of fishes coming from the Kerguelen Islands. Science et Pêche 303:1-11

Eastman JT (1985) Pleuragramma antarcticum (Pisces, Nototheniidae) as food for other fishes in McMurdo Sound, Antarctica. Polar Biol 4:155-160. https://doi.org/10.1007/BF00263878

Eastman JT, DeVries AL (1982) Buoyancy studies of Notothenioid fishes in McMurdo Sound, Antarctica. Copeia 2:385-393. https ://doi.org/10.2307/1444619

Eastman JT, Eakin RR (2000) An updated species list for notothenioid fish (Perciformes; Notothenioidei), with comments on Antarctic species. Arch Fish Mar Res 48(1): 11-20

Eastman JT, Hubold G (1999) The fish fauna of the Ross Sea, Antarctica. Antarct Sci 11(3):293-304. https://doi.org/10.1017/S0954 102099000383

Eicken H (1992) The role of sea ice in structuring Antarctic ecosystems. Polar Biol 12:3-13. https://doi.org/10.1007/BF00239960

Falk-Petersen S, Hagen W, Kattner G, Clarke A, Sargent J (2000) Lipids, trophic relationships and biodiversity in Arctic and Antarctic krill. Can J Fish Aquat Sci 57:178-191. https://doi. org/10.1139/f00-194

FAO (2003) Food energy-methods of analysis and conversion factors. Report of a technical workshop, Rome, 3-6 December 2002

Färber-Lorda J (1986) Etudes biologiques, energétiques et biochimiques du krill antarctique (Euphausia superba et Thysanoessa macrura), récolté au cours de la campagne FIBEX (fevrier 1981), Université d'Aix-Marseille II

Färber-Lorda J, Mayzaud P (2010) Morphology and total lipids in Thysanoessa macura from the southern part of the Indian Ocean during summer spatial and sex differences. Deep Sea Res II 57:565-571. https://doi.org/10.1016/j.dsr2.2009.11.001 
Färber-Lorda J, Gaudy R, Mayzaud P (2009a) Elemental composition, biochemical composition and caloric value of Antarctic krill. Implications in energetics and carbon balances. J Mar Syst 78:518-524. https://doi.org/10.1016/j.jmarsys.2008.12.021

Färber-Lorda J, Beier E, Mayzaud P (2009b) Morphological and biochemical differentiation in Antarctic krill. J Mar Syst 78:525535. https://doi.org/10.1016/j.jmarsys.2008.12.022

Favero M, Silva P, Ferreva G (1997) Trophic relationships between the kelp gull and the Antarctic limpet at King George Island (South Shetland Islands, Antarctica) during the breeding season. Polar Biol 17(5):431-436. https://doi.org/10.1007/s003000050137

Fenaughty JM, Eastman JT, Sidell BD (2008) energy spawning Biological implications of low condition factor "axe handle" specimens of the Antarctic toothfish, Dissostichus mawsoni, from the Ross Sea. Antarct Sci 20(6):537-551. https://doi.org/10.1017/ S0954102008001430

Fernández-Álamo MA, Thuesen EV (1999) Polychaeta. In: Boltovskoy D (ed) South Atlantic zooplankton. Backhuys Publishers, Leiden, pp 595-619

Finlay BJ, Uhlig G (1981) Calorific and carbon values of marine and freshwater protozoa. Helgoländer Meeresunters 34:401-412. https://doi.org/10.1007/BF01995913

Flores H, Van de Putte AP, Siegel V, Pakhomov EA, Van Franeker JA, Meesters HWG, Volckaert FAM (2008) Distribution, abundance and ecological relevance of pelagic fishes in the Lazarev Sea, Southern Ocean. Mar Ecol Prog Ser 367:271-282. https://doi. org/10.3354/meps07530

Flores H, Van Franeker JA, Cisewski B, Leach H, Van de Putte AP, Meesters EHWG, Bathmann U, Wolff WJ (2011) Macrofauna under sea ice and in the open surface layer of the Lazarev Sea, Southern Ocean. Deep Sea Res II 58:1948-1961. https://doi. org/10.1016/j.dsr2.2011.01

Flores H, Van Franeker JA, Siegel V, Haraldsson M, Strass V, Meesters EH, Bathmann U, Wolff WJ (2012) The association of Antarctic krill Euphausia superba with the under-ice habitat. PLoS One 7(2):e31775. https://doi.org/10.1371/journal.pone.0031775

Flores H, Hunt BPV, Kruse S, Pakhomov EA, Siegel V, Van Franeker JA, Strass V, Van de Putte AP, Meesters EHWG, Batmann U (2014) Seasonal changes in the vertical distribution and community structure of Antarctic macrozooplankton and micronekton. Deep Sea Res I 84:127-141. https://doi.org/10.1016/j. dsr.2013.11.001

Flores H, Van Franeker JA, Van de Putte AP, Castellani G, Schaafsma FL, Ehrlich E, Vortkamp M, Meijboom A, Feij B, Van Dorssen M (2015) Sea ice ecology, pelagic food web and top predator studies. In: Boebel O (ed) Reports on polar and marine research, vol 689. pp 102-126, Alfred Wegener Institute, Helmholtz Centre for Polar and Marine Research, Germany

Foxton P (1956) The distribution of the standing crop of zooplankton in the Southern Ocean. Discov Rep 26:191-236

Friedrich C, Hagen W (1994) Lipid contents of five species of notothenioid fish from high-Antarctic waters and ecological implications. Polar Biol 14:359-369. https://doi.org/10.1007/BF002 40256

Giguère LA, St-Pierre JF, Bernier B, Vézina A, Rondeau JG (1989) Can we estimate the true weight of zooplankton samples after chemical preservation? Can J Fish Aquat Sci 46(3):522-527. https://doi.org/10.1139/f89-070

Gili JM, Rossi S, Pagès F, Orejas C, Teixidó N, López-González PJ, Arntz WE (2006) A new trophic link between the pelagic and benthic systems on the Antarctic shelf. Mar Ecol Prog Ser 322:43-49. https://doi.org/10.3354/meps322043

Gnaiger E, Bitterlich G (1984) Proximate biochemical composition and caloric content calculated from elemental CHN analysis: a stoichiometric concept. Oecologia 62(3):289-298. https://doi. org/10.1007/BF00384259
Goldsworthy SD, He X, Tuck GN, Lewis M, Williams R (2001) Trophic interactions between the Patagonian toothfish, its fishery, and seals and seabirds around Macquarie Island. Mar Ecol Prog Ser 218:283-302. https://doi.org/10.3354/meps218283

Gon O, Heemstra PC (1990) Fishes of the Southern Ocean. J.L.B. Smith Institute of Ichthyology Publishers, Grahamstown

Grant S, Constable A, Raymond B, Doust S (2006) Bioregionalization of the Southern Ocean: report of experts workshop, WWFAustralia and ARC CRC, Hobart, September 2006

Greely TM, Gartner JV, Torres JJ (1999) Age and growth of Electrona antarctica (Pisces: Myctophidae), the dominant mesopelagic fish of the Southern Ocean. Mar Biol 133:145-158. https://doi. org/10.1007/s002270050453

Green B, Gales RP (1990) Water, sodium, and energy turnover in freeliving penguins. In: Davis LS, Darby JT (eds) Penguin biology. Academic Press, San Diego, pp 245-268

Hagen W, Kattner G, Graeve M (1993) Calanoides acutus and Calanus propinquus, Antarctic copepods with different lipid storage modes via wax esters or triacylglycerols. Mar Ecol Prog Ser 97:135-142

Hagen W, Van Vleet ES, Kattner G (1996) Seasonal lipid storage as overwintering strategy of Antarctic krill. Mar Ecol Prog Ser 134:85-89. https://doi.org/10.3354/meps134085

Hagen W, Kattner G, Friedrich C (2000) The lipid compositions of high-Antarctic notothenioid fish species with different life strategies. Polar Biol 23:785-791. https://doi.org/10.1007/s003000000 153

Hamner WM, Hamner PP, Obst BS, Carleton JH (1989) Field observations on the ontogeny of schooling of Euphausia superba furciliae and its relationship to ice in Antarctic waters. Limnol Oceanogr 34(2):451-456. https://doi.org/10.4319/lo.1989.34.2.0451

Haraldsson M, Siegel V (2014) Seasonal distribution and life history of Thysanoessa macrura (Euphausiacea, Crustacea) in high latitude waters of the Lazarev Sea, Antarctica. Mar Ecol Prog Ser 495:105-118. https://doi.org/10.3354/meps 10553

Hartman KJ, Brandt SB (1995) Estimating energy density of fish. Trans Am Fish Soc 124:347-355. https://doi.org/10.1577/1548-8659

Heine JN, McClintock JB, Slattery M, Weston J (1991) Energetic composition, biomass, and chemical defence in the common Antarctic nemertean Parborlasia corrugatus Mclntosh. J Exp Mar Biol Ecol 153:15-25. https://doi.org/10.1016/S0022-0981(05)80003 $-6$

Henken AM, Lucas H, Tijssen PAT, Machiels MAM (1986) A comparison between methods used to determine the energy content of feed, fish and faeces samples. Aquaculture 58:195-201. https ://doi.org/10.1016/0044-8486(86)90085-2

Heywood KJ, Locarnini RA, Frew RD, Dennis PF, King BA (1998) Transport and water masses of the Antarctic Slope Front system in the eastern Weddell Sea, in Ocean, Ice, and Atmosphere: interactions at the Antarctic Continental Margin. Antarct Res Ser 75:203-214. https://doi.org/10.1029/AR075p0203

Higgs DA, Macdonald JS, Levings CD, Dosanjh BS (1995) Nutrition and feeding habits in relations to life history stage. In: Groot C, Margolis L, Clarke WC (eds) Physiological ecology of Pacific salmon. UBC Press, Vancouver

Hindell MA (1989) The diet of Gentoo penguin Pygoscelis papua at Macquarie Island: winter and early breeding season. Emu 89:7178. https://doi.org/10.1071/MU9890071

Hislop JRG, Harris MP, Smith JGM (1991) Variation in de calorific value and total energy content of the lesser sandeel (Ammodytes marinus) and other fish preyed on by seabirds. J Zool Lond 224:501-517. https://doi.org/10.1111/j.1469-7998.1991.tb060 39. $\mathrm{x}$

Hondolero D, Bluhm BA, Iken K (2012) Caloric content of dominant benthic species from the northern Bering and Chukchi Seas: 
historical comparisons and the effects of preservation. Polar Biol 35:637-644. https://doi.org/10.1007/s00300-011-1107-x

Hubold G (1990) Seasonal patterns in ichthyoplankton distribution and abundance in the southern Weddell Sea. In: Kerry KR, Hempel G (eds) Antarctic ecosystems: ecological change and conservation. Springer, Berlin, pp 149-158

Hubold G (1991) Ecology of notothenioid fish in de Weddell Sea. In: di Preisco G, Maresca B, Tota B (eds) Biology of Antarctic fish. Springer, Berlin, pp 3-22

Hubold G, Ekau W (1990) Feeding patterns of post-larval and juvenile notothenioids in the southern Weddell Sea (Antarctica). Polar Biol 10:255-260. https://doi.org/10.1007/BF00238422

Hubold G, Hagen W (1997) Seasonality of feeding and lipid content in juvenile Pleuragramma antarcticum (Pisces: Nototheniidae) from the southern Weddell Sea. In: Battaglia B, Valencia J, Walton DWH (eds) Antarctic communities, species structure and survival. Cambridge University Press, Cambridge, pp 1-464

Hunt BPV, Pakhomov EA, Hosie GW, Sigel V, Ward P, Bernard K (2008) Pteropods in Southern Ocean ecosystems. Prog Oceanogr 78:193-221. https://doi.org/10.1016/j.pocean.2008.06.001

Ikeda T, Dixon P (1982) Body shrinkage as a possible over-wintering mechanism of the Antarctic krill, Euphausia superba Dana. J Exp Mar Biol Ecol 62:143-151

Ishii T, Shinohara N, Fujise Y, Nishiwaki Matsuoka K (1998) Interannual changes in body fat condition index of minke whales in the Antarctic. Mar Ecol Prog Ser 175:1-12

Ishii T, Bengston JL, Boveng PL, Takao Y, Jansen JK, Hiruki-Raring LM, Cameron MF, Okamura H, Hayashi T, Naganobu M (2007) Provisioning strategies of Antarctic fur seal and chinstrap penguins produce different responses to distribution of common prey and habitat. Mar Ecol Prog Ser 344:277-297. https://doi.org/10.3354/meps06873

Jackson S (1986) Assimilation efficiencies of white-chinned petrels (Procellaria, Aequinoctialis) fed different prey. Comp Biochem Physiol 85A(2):301-303. https://doi.org/10.1016/03009629(86)90254-9

Jackson S, Place AR, Seiderer LJ (1992) Chitin digestion and assimilation by seabirds. Auk 109(4):758-770

Jacobs SS (1991) On the nature and significance of the Antarctic Slope Front. Mar Chem 35:9-24. https://doi.org/10.1016/ S0304-4203(09)90005-6

Jarman SN, McInnes J, Faux C, Polanowski AM, Marthick J, Deagle BE, Southwell C, Emmerson L (2013) Adélie penguin population diet monitoring by analysis of food DNA in scats. PLoS One 8(12):e82227. https://doi.org/10.1371/journal.pone.00822 27

Jennings S, Varsani A, Dugger KM, Ballard G, Ainley DG (2016) Sex-based differences in Adélie penguin (Pygoscelis adeliae) chick growth rates and diet. PLoS One 11(3):e0149090. https ://doi.org/10.1371/journal.pone.0149090

Kamler E (1992) Early life history of fish: and energetics approach. Chapman \& Hall, London

Kane JE (1966) The distribution of Parathemisto gaudichaudii (Guér.), with observations on its life-history in the 0 to $20 \mathrm{E}$ sector of the Southern Ocean. Discov Rep 34:163-198

Kawaguchi S, King R, Meijers R, Osborn JE, Swadling KM, Ritz DA, Nicol S (2010) An experimental aquarium for observing the schooling behaviour of Antarctic krill (Euphausia superba). Deep Sea Res II 57:683-692. https://doi.org/10.1016/j. dsr2.2009.10.017

Kersting K (1972) A nitrogen correction for caloric values. Limnol Oceanogr 17:643-644. https://doi.org/10.4319/lo.1972.17.4.0643

Kirkman SP, Wilson W, Klages NTW, Bester MN, Isaksen K (2000) Diet and estimated food consumption of Antarctic fur seals at Bouvetøya during summer. Polar Biol 23:745-752. https://doi. org/10.1007/s003000000145
Klages N (1989) Food and feeding ecology of emperor penguins in the eastern Weddell Sea. Polar Biol 9:385-390. https://doi. org/10.1007/BF00442529

Kock KH (1992) Antarctic fish and fisheries. Cambridge University Press Cambridge, New York, p 359

Kohlbach D, Lange BA, Schaafsma FL, David C, Vortkamp M, Graeve M, Van Franeker JA, Krumpen T, Flores H (2017) Ice algae-produced carbon is critical for overwintering of Antarctic krill Euphausia superba. Front Mar Sci 4:310. https://doi. org/10.3389/fmars.2017.00310

Kouwenberg JHM, Razouls C, Desreumaux N (2014) Chapter 6.6. Southern Ocean pelagic copepods. In: De Broyer C, Koubbi P, Griffiths HJ, Raymond B, Udekem d'Acoz Cd' et al (eds) Biogeographic Atlas of the Southern Ocean. Scientific Committee on Antarctic Research, Cambridge, pp 290-296

Kruse S, Brey T, Bathmann U (2010) Role of midwater chaetognaths in Southern Ocean pelagic energy flow. Mar Ecol Prog Ser 416:105-113. https://doi.org/10.3354/meps08773

La Mesa M, Eastman JT, Vacchi M (2004) The role of notothenioid fish in the food web of the Ross Sea shelf waters: a review. Polar Biol 27:321-338. https://doi.org/10.1007/s00300-004-0599-z

Lamprecht I (1999) Combustion calorimetry. In: Kemp RB (ed) Handbook of thermal analysis and calorimetry, vol 4. From macromolecules to man. Elsevier Science, New York, pp 175-218

Larson RJ (1986) Water content, organic content, and carbon and nitrogen composition of medusae from the northeast Pacific. J Exp Mar Biol Ecol 99:107-120. https://doi.org/10.1016/00220981(86)90231-5

Lawrence JM (1976) Patterns of lipid storage in post-metamorphic marine invertebrates. Am Zool 16:747-762. https://doi. org/10.1093/icb/16.4.747

Lawrence JM, Guille A (1982) Organic composition of tropical, polar and temperate-water echinoderms. Comp Biochem Physiol 72B:283-287. https://doi.org/10.1016/0305-0491(82)90047-5

Laws RM (1977) Seals and whales of the Southern Ocean. Philos Trans R Soc B 279:81-96. https://doi.org/10.1098/rstb.1977.0073

Lea MA, Nichols PD, Wilson G (2002) Fatty acid composition of lipid-rich myctophids and mackerel icefish (Champsocephalus gunnari)-Southern Ocean food-web implications. Polar Biol 25:843-854. https://doi.org/10.1007/s00300-002-0428-1

Lea MA, Guinet C, Cherel Y, Duhamel G, Dubroca L, Pruvost P, Hindell M (2006) Impacts of climatic anomalies on provisioning strategies of a Southern Ocean predator. Mar Ecol Prog Ser 310:77-94

Lenky C, Eisert R, Oftedal OT, Metcalf V (2012) Proximate composition and energy density of nototheniid and myctophid fish in McMurdo Sound and the Ross Sea, Antarctica. Polar Biol 35:717-724. https://doi.org/10.1007/s00300-011-1116-9

Lizotte MP (2001) The contributions of sea ice algae to Antarctic marine primary production. Am Zool 41(1):57-73. https://doi. org/10.1668/0003-1569

Márquez ME, Quadraccia A, Portela M, Sambucetti M, Sanahuja J 1978. Antarctic krill (Euphausia superba Dana): composition and nutritive value. Abstracts free communication. In: XI international congress of nutrition, August 27-September 1, 1978, Rio de Janeiro, Brazil. Abstract no. 603, p 366

Matsuoka K, Skoglund A, Roth G (2018) Quantarctica [data set]. Nor Polar Inst. https://doi.org/10.21334/npolar.2018.8516e961

Mayzaud P, Boutoute M (2015) Dynamics of lipid and fatty acid composition of the hyperiid amphipod Themisto: a bipolar comparison with special emphasis on seasonality. Polar Biol 38:10491065. https://doi.org/10.1007/s00300-015-1666-3

Mayzaud P, Albessard E, Cuzin-Roudy J (1998) Changes in lipid composition of the Antarctic krill Euphausia superba in the Indian sector of the Antarctic Ocean: influence of geographical location, 
sexual maturity stage and distribution among organs. Mar Ecol Prog Ser 173:149-162. https://doi.org/10.3354/meps173149

McClintock JB (1987) Investigation of the relationship between invertebrate predation and biochemical composition, energy content, spicule armament and toxicity of benthic sponges at McMurdo Sound, Antarctica. Mar Biol 94:479-487. https://doi. org/10.1007/BF00428255

McClintock JN (1989) Energetic composition, reproductive output, and resource allocation of Antarctic asteroids. Polar Biol 9:147-153. https://doi.org/10.1007/BF00297169

McClintock JB, Pearse JS (1987) Biochemical composition of Antarctic echinoderms. Comp Biochem Physiol 86B:683-687. https:// doi.org/10.1016/0305-0491(87)90211-2

McClintock JB, Amsler MO, Amsler CD, Southworth KJ, Petrie C, Baker BJ (2004) Biochemical composition, energy content and chemical antifeedant and antifoulant defenses of the colonial Antarctic ascidian Distaplia cylindrica. Mar Biol 145:885-894. https://doi.org/10.1007/s00227-004-1388-5

McClintock JB, Amsler MO, Amsler CD, Baker BJ (2006) The biochemical composition, energy content, and chemical antifeedant defenses of the common Antarctic Peninsular sea stars Granaster nutrix and Neosmilaster georgianus. Polar Biol 29:615-623. https://doi.org/10.1007/s00300-005-0097-y

McInnes JC, Aldeman R, Lea MA, Raymond B, Deagle BE, Phillips RA, Stanworth A, Thompson DR, Catry P, Weimerkirch H, Suazo CG, Gras M, Jarman SN (2017) High occurrence of jellyfish predation by black-browed and Campbell albatross identified by DNA metabarcoding. Mol Ecol. https://doi.org/10.1111/ mec. 14245

Meiners KM, Vancoppenolle M, Thanassekos S, Dieckmann GS, Thomas DN, Tison JL, Arrigo KR, Garrison DL, McMinn A, Lannuzal D, Van der Merwe P, Swadling KM, Smith WO Jr, Melnikov I, Raymond B (2012) Chlorophyll $a$ in Antarctic sea ice from historical ice core data. Geophys Res Lett 39(21):L21602. https://doi.org/10.1029/2012GL053478

Meyer B, Fuentes V, Guerra C, Schmidt K et al (2009) Physiology, growth, and development of larval krill Euphausia superba in autumn and winter in the Lazarev Sea, Antarctica. Limnol Oceanogr 54:1595-1614. https://doi.org/10.4319/lo.2009.54.5.1595

Milisenda G, Rosa S, Fuentes VL, Boero F, Guglielmo L, Purcell JE, Piriano S (2014) Jellyfish as prey: frequency of predation and selective foraging of Boops boops (Vertebrata, Actinopterygii) on the Mauve stinger Pelagia noctiluca (Cnidaria, Scyphozoa). PLoS One 9(4):e94600. https://doi.org/10.1371/journ al.pone. 0094600

Nagy KA, Obst BS (1992) Food and energy requirements of Adélie Penguins (Pygoscelis adeliae) on the Antarctic Peninsula. Physiol Zool 65(6):1271-1284. https://doi.org/10.1086/physz ool.65.6.30158279

Near TJ, Russo SE, Jones CD, DeVries AL (2003) Ontogenetic shift in buoyancy and habitat in the Antarctic toothfish, Dissostichus mawsoni (Perciformes: Nototheniidae). Polar Biol 26:124-128. https://doi.org/10.1007/s00300-002-0459-7

Nicol S, Pauly T, Bindoff NL, Wright S, Thiele D, Hosie GW, Strutton PG, Woehler E (2000) Ocean circulation off east Antarctica affects ecosystem structure and sea-ice extent. Nature 406:504507. https://doi.org/10.1038/35020053

Nordhausen W (1994) Distribution and diel vertical migration of the euphausiid Thysanoessa macrura in Gerlache Strait, Antarctica. Polar Biol 14:219-229. https://doi.org/10.1007/bf00239170

Normant M, Chrobak M, Szaniawska A (2002) Energy value and chemical composition (CHN) of the Chinese mitten crab Eriocheir sinensis (Decapoda, Grapsidae) from the Baltic Sea. Thermochim Acta 394:233-237. https://doi.org/10.1016/S0040 $-6031(02) 00259-9$
Norrbin F, Båmstedt U (1984) Energy contents in benthic and planktonic invertebrates of Kosterfjorden, Sweden. A comparison of energetic strategies in marine organism groups. Ophelia 23(1):47-64. https://doi.org/10.1080/00785236.1984.10426604

Oehlenschläger J (1991) Chemical comparison of the flesh and other tissues of Antarctic fish species of the families Channichtyidae and Nototheniidae. Food Chem 40:159-167

Orsi AH, Whitworth T III, Nowlin WD Jr (1995) On the meridional extent and fronts of the Antarctic Circumpolar Current. Deep Sea Res I 42(5):641-673. https://doi.org/10.1016/09670637(95)00021-W

Paine RT (1964) Ash and calorie determinations of sponge and opisthobranch tissues. Ecology 45(2):384-387. https://doi. org/10.2307/1933856

Paine RT (1971) The measurement and application of the calorie to ecological problems. Ann Rev Ecol Syst 2:145-164. https://doi. org/10.1146/annurev.es.02.110171.001045

Pakhomov EA (1995) Demographic studies of Antarctic krill Euphausia superba in the Cooperation and Cosmonaut Seas (Indian sector of the Southern Ocean). Mar Ecol Prog Ser 119:45-61. https ://doi.org/10.1139/cjfas-57-S3-68

Pakhomov EA (2004) Salp/krill interactions in the eastern Atlantic sector of the Southern Ocean. Deep Sea Res II 51:2645-2660. https://doi.org/10.1016/j.dsr2.2001.03.001

Pakhomov EA, McQuaid CD (1996) Distribution of surface zooplankton and seabirds across the Southern Ocean. Polar Biol 16:271-286. https://doi.org/10.1007/s003000050054

Pakhomov EA, Perissinotto R (1996) Antarctic neritic krill Euphausia crystallorophias: spatio-temporal distribution, growth and grazing rates. Deep Sea Res I 42(1):59-87. https://doi. org/10.1016/0967-0637(95)00094-1

Pakhomov EA, Perissinotto R, Froneman PW (1999) Predation impact of carnivorous macrozooplankton and micronekton in the Atlantic sector of the Southern Ocean. J Mar Syst 19:4764. https://doi.org/10.1016/S0924-7963(98)00023-2

Pakhomov EA, Perissinotto R, McQuaid CD, Froneman PW (2000) Zooplankton structure and grazing in the Atlantic sector of the Southern Ocean in late austral summer 1993 Part 1. Ecological zonation. Deep Sea Res I 47:1663-1686. https://doi. org/10.1016/S0967-0637(99)00122-3

Pakhomov EA, Froneman PW, Perissinotto R (2002) Salp/krill interactions in the Southern Ocean: spatial segregation and implications for the carbon flux. Deep Sea Res II 49:1881-1907. https ://doi.org/10.1016/S0967-0645(02)00017-6

Pakhomov EA, Dubischar CD, Hunt BPV, Strass V, Cisewski B, Siegel V, Von Harbou L, Gurney L, Kitchener J, Bathmann $\mathrm{U}$ (2011) Biology and life cycles of pelagic tunicates in the Lazarev Sea, Southern Ocean. Deep Sea Res II 58:1677-1689. https://doi.org/10.1016/j.dsr2.2010.11.014

Pandit AR, Magar NG (1972) Chemical composition of Sepia orientalis and Loligo vulgaris. Fish Technol 9:122-125

Percy JA, Fife FJ (1981) The biochemical composition and energy content of Arctic marine macrozooplankton. Arctic 34(4):307-313. https://doi.org/10.14430/arctic2533

Phillips KL, Jackson GD, Nichols PD (2001) Predation on myctophids by the squid Moroteuthis ingens around Macquarie and Heard Islands: stomach contents and fatty acid analyses. Mar Ecol Prog Ser 215:179189. https://doi.org/10.3354/meps215179

Piatkowski U (1985) Distribution, abundance and diurnal migration of macrozooplankton in Antarctic surface waters. Meeresforschung Rep Mar Res 30:264-279. https://doi.org/10.2312/meeresfors chung_30_264-279

Platt T, Irwin B (1973) Caloric content of phytoplankton. Limnol Oceanogr 18:306-310. https://doi.org/10.4319/lo.1973.18.2.0306

Pond D, Watkins J, Priddle J, Sargent J (1995) Variation in the lipid content and composition of Antarctic krill Euphausia superba 
at South Georgia. Mar Ecol Prog Ser 117:49-57. https://doi. org/10.3354/meps117049

Quetin LB, Ross RM (1991) Behavioural and physiological characteristics of the Antarctic krill, Euphausia superba. Am Zool 31(1):49-63. https://doi.org/10.1093/icb/31.1.49

Quetin LB, Ross RM (2003) Episodic recruitment in Antarctic krill Euphausia superba in the Palmer LTER region. Mar Ecol Prog Ser 259:185-200. https://doi.org/10.3354/meps259185

R Core Team (2015) R: a language and environment for statistical computing. R Foundation for Statistical Computing, Vienna

Reid K, Trathan PN, Croxall JP, Hill HJ (1996) Krill caught by predators and nets: differences between species and techniques. Mar Ecol Prog Ser 140:13-20. https://doi.org/10.3354/meps140013

Reinhardt SB, Van Vleet ES (1986) Lipid composition of twenty-two species of Antarctic midwater zooplankton and fish. Mar Biol 91(2):149-159

Ridoux V (1994) The diets and dietary segregation of seabirds at the subantarctic Crozet Islands. Mar Ortithol 22:1-192

Riffenburgh B (2007) Encyclopedia of the Antarctic. Routledge, New York

Robbins CT (1983) Wildlife feeding and nutrition. Academic Press, London, p 343

Rodhouse PGK, Griffiths HJ, Xavier JC (2014) Chapter 6.5 Southern Ocean Squid. In: De Broyer C, Koubbi P, Griffiths HJ, Raymond B, Udekem d'Acoz Cd' et al (eds) Biogeographic Atlas of the Southern Ocean. Scientific Committee on Antarctic Research, Cambridge, pp 284-289

Ross RM, Quetin LB (1986) How productive are Antarctic krill? BioScience 36(4):264-269. https://doi.org/10.2307/1310217

Ross RM, Quetin LB, Newberger T, Shaw CT, Jones JL, Oakes SA, Moore KJ (2014) Trends, cycles, interannual variability for three pelagic species west of the Antarctic peninsula 1993-2008. Mar Ecol Prog Ser 515:11-32. https://doi.org/10.3354/meps10965

Ruck KE, Steinberg DK, Canuel EA (2014) Regional differences in quality of krill and fish as prey along the Western Antarctic Peninsula. Mar Ecol Prog Ser 509:39-55. https://doi.org/10.3354/ meps 10868

Salonen K, Sarvala J, Hakala I, Vijanen ML (1976) The relation of energy and organic carbon in aquatic invertebrates. Limnol Oceanogr 21(5):724-730. https://doi.org/10.4319/ lo.1976.21.5.0724

Saunders RA, Tarling GA (2018) Southern Ocean mesopelagic fish comply with Bergmann's rule. Am Nat 191(3):343-351

Schaafsma FL, David C, Pakhomov EA, Hunt BPV, Lange BA, Flores H, Van Franeker JA (2016) Size and stage composition of age class 0 Antarctic krill (Euphausia superba) in the ice-water interface layer during winter/early spring. Polar Biol 39:15151526. https://doi.org/10.1007/s00300-015-1877-7

Schaafsma FL, Kohlbach D, David C, Lange BA, Graeve M, Flores H, Van Franeker JA (2017) Spatio-temporal variability in the winter diet of larval and juvenile Antarctic krill, Euphausia superba, in ice-covered waters. Mar Ecol Prog Ser 581:101-115. https://doi. org/10.3354/meps 12309

Schnack-Schiel SB, Hagen W, Mizdalski E (1998) Seasonal carbon distribution of copepods in the eastern Weddell Sea, Antarctica. J Mar Syst 17:305-311. https://doi.org/10.1016/S0924 -7963(98)00045-1

Schnack-Schiel SB, Thomas DN, Haas C, Dieckmann GS, Alheit R (2001) The occurrence of the copepods Stephos longipes (Calanoida) and Drescheriella glacialis (Harpacticoida) in the summer sea ice in the Weddell Sea, Antarctica. Antarct Sci 13(2):150 157. https://doi.org/10.1017/S0954102001000232

Shul'man GE (1974) Life cycles of fish. Keter Publishing House, Jerusalem
Siegel V (1987) Age and growth of Antarctic Euphausiacea (Crustacea) under natural conditions. Mar Biol 96:483-495. https://doi. org/10.1007/BF00397966

Siegel V (2012) Krill stocks in high latitudes of the Antarctic Lazarev Sea: seasonal and interannual variation in distribution, abundance and demography. Polar Biol 25:1151-1177. https://doi. org/10.1007/s00300-012-1162-y

Solokov S, Rintoul SR (2009) Circumpolar structure and distribution of the Antarctic Circumpolar Current fronts: 1. Mean circumpolar paths. J Geophys Res 114:C11018. https://doi.org/10.1029/2008J C005108

Southwell C, Bengston J, Bester M, Blix AS, Bornemann H, Boveng P, Cameron M, Forcada J, Laake J, Nordøy E, Plötz J, Rogers T, Southwell D, Steinhage D, Stewart BS, Trathan P (2012) A review of data on abundance, trends in abundance, habitat use and diet of ice-breeding seals in the Southern Ocean. CCAMLR Sci 19:49-74

Spinidonov VA (1995) Spatial and temporal variability in reproductive timing of Antarctic krill (Euphausia superba Dana). Polar Biol 15:161-174. https://doi.org/10.1007/BF00239056

Tamura T, Konishi K (2009) Feeding habits and prey consumption of Antarctic minke whale (Balaenoptera bonaerensis) in the Southern Ocean. J Northw Atl Fish Sci 42:13-25. https://doi. org/10.2960/J.v42.m652

Thiebot JB, Ito K, Raclot T, Poupart T, Kato A, Ropert-Coudert Y, Takahashi A (2016) On the significance of Antarctic jellyfish as food for Adélie penguins, as revealed by video loggers. Mar Biol 163:108. https://doi.org/10.1007/s00227-016-2890-2

Thiebot JB, Arnould JPY, Gómez-Laich A, Ito K, Kato A, Mattern T, Mitamura H, Noda T, Poupart T, Quintana F, Raclot T, Ropert-Coudert Y, Sala JE, Seddon PJ, Sutton GJ, Yoda K, Takahashi A (2017) Jellyfish and other gelata as food for four penguin species-insights from predator-borne videos. Front Ecol Envion 15(8):437-441. https://doi.org/10.1002/fee.1529

Tierney M, Hindell M, Goldsworthy S (2002) Energy content of mesopelagic fish from Macquarie Island. Antarct Sci 14(3):225230. https://doi.org/10.1017/S0954102002000020

Torres JJ, Donnelly J, Hopkins TL, Lancraft TM, Aaarset AV, Ainley DG (1994) Proximate composition and overwintering strategies of Antarctic micronektonic Crustacea. Mar Ecol Prog Ser 113:221-232. https://doi.org/10.3354/meps113221

Trathan PH, Forcada J, Murphy EJ (2007) Environmental forcing and Southern Ocean marine predator populations: effects of climate change and variability. Philos Trans R Soc B 362:2351-2365. https://doi.org/10.1098/rstb.2006.1953

Tréguer P, Jacques G (1992) Dynamics of nutrients and phytoplankton, and fluxes of carbon, nitrogen and silicon in the Antarctic Ocean. Polar Biol 12:149-162. https://doi.org/10.1007/BF00238255

Vacchi M, La Mesa M, Dalu M, MacDonald J (2004) Early life stages in the life cycle of Antarctic silverfish, Pleuragramma antarcticum in Terra Nova Bay, Ross Sea. Antarct Sci 16(3):299-305. https://doi.org/10.1017/S0954102004002135

Vallet C, Labat JP, Smith M, Koubbi P (2011) Interannual variations in euphausiid life stage distribution in the Dumont d'Urville Sea from 2004 to 2008. Polar Sci 5:166-178. https://doi. org/10.1016/j.polar.2011.03.006

Van de Putte AP (2008) Ecology and evolution of fishes in the Southern Ocean, with special focus on the myctophid Electrona antarctica. Dissertation, Catholic University Leuven

Van de Putte AP, Flores H, Volckaert F, Van Franeker JA (2006) Energy content of Antarctic mesopelagic fishes: implications for the marine food web. Polar Biol 29:1045-1051. https://doi. org/10.1007/s00300-006-0148-z

Van de Putte AP, Jackson GD, Pakhomov E, Flores H, Volckaert FAM (2010) Distribution of squid and fish in the pelagic zone of the Cosmonaut Sea and Prydz Bay region during the 
BROKE-West campaign. Deep Sea Res II 57:956-967. https:// doi.org/10.1016/j.dsr2.2008.02

Van Franeker JA (1992) Top predators as indicators for ecosystem events in the confluence zone and marginal ice zone of the Weddell and Scotia seas, Antarctica, November 1988 to January 1989 (EPOS Leg 2). Polar Biol 12:93-102. https://doi.org/10.1007/ BF00239969

Van Franeker JA, Bathmann UV, Mathot S (1997) Carbon fluxes to Antarctic top predators. Deep Sea Res II 44:435-455. https:// doi.org/10.1016/S0967-0645(96)00078-1

Van Franeker JA, Williams R, Imber MJ, Wolff WJ (2001) Diet and foraging ecology of Southern Fulmar Fulmarus glacialoides, Antarctic Petrel Thalassoica antarctica, Cape Petrel Daption capense and Snow Petrels Pagodroma nivea ssp. on Ardery Island, Wilkes Land, Antarctica. In: Van Franeker JA (ed) Mirrors in ice. University of Groningen. https://www.researchgate.net/publi cation/288000220

Van Franeker JA, Van den Brink NW, Bathmann UV, Pollard RT, De Baar HJW, Wolff WJ (2002) Responses of seabirds, in particular prions (Pachyptila sp.), to small-scale processes in the Antarctic Polar Front. Deep Sea Res II 49(12):3931-3950. https://doi. org/10.1016/s0967-0645(02)00118-2

Vanella FA, Calvo J, Morriconi ER, Aureliano DR (2005) Somatic energy content and histological analysis of the gonads in Antarctic fish from the Scotia Arc. Sci Mar 69:305-316. https://doi. org/10.3989/scimar.2005.69s2305

Virtue P, Nichols PD, Nicol S, Hosie G (1996) Reproductive trade-off in male Antarctic krill, Euphausia superba. Mar Biol 126:521527. https://doi.org/10.1007/BF00354634

Virtue P, Meyer B, Freier U, Nichols PD, Jia Z, King R, Virtue J, Swadling KM, Meiners KM, Kawaguchi S (2016) Condition of larval (furciliaVI) and one year old juvenile Euphausia superba during the winter-spring transition in East Antarctica. Deep Sea Res II 131:182-188. https://doi.org/10.1016/j.dsr2.2016.02.001

Vlieg P (1984) Proximate composition of New Zealand squid species. N Z J Sci 27:145-150

VNIRO (2000) Chemical composition and processing properties of marine and ocean fishes: handbook. M VNIRO, Moscow

Vollenweider JJ, Heintz RA, Schaufler L, Bradshaw R (2011) Seasonal cycles in whole-body proximate composition and energy content of forage fish vary with water depth. Mar Biol 158:413-427. https://doi.org/10.1007/s00227-010-1569-3

Waluda CM, Hill SL, Peat HJ, Trathan PN (2012) Diet variability and reproductive performance of macaroni penguins Eudyptes chrysolophus at Bird Island, South Georgia. Mar Ecol Prog Ser 466:261-274. https://doi.org/10.3354/meps09930

Williams R, Robins D (1979) Calorific, ash, carbon and nitrogen content in relation to length and dry weight of Parathemisto gaudichaudi (Amphipoda: Hyperiidea) in the north east Atlantic Ocean. Mar Biol 52:247-252. https://doi.org/10.1007/BF003 98138

Yanagimoto M, Kato N, Yokoyama Y, Kobayashi T, Kimura S (1979) Chemical compositions of Antarctic Krill (Euphausia superba) for the evaluation of processing. Bull Jpn Soc Sci Fish 45:369374. https://doi.org/10.2331/suisan.45.369

Zeidler W, De Broyer C (2014) Amphipoda Hyperiidea. In: De Broyer C, Koubbi P, Grffiths HJ, Raymond B, Udekem d'Acoz Cd' et al (eds) Biogeographic Atlas of the Southern Ocean. Scientific Committee on Antarctic Research, Cambridge, pp 303-308 